\title{
Odd Man Out: How Stephen Harper Changed Canada's Relations with the United Nations
}

by

Michael Blanchfield

A thesis submitted to the Faculty of Graduate and Postdoctoral Affairs in partial fulfillment of the requirements for the degree of

\author{
Master of Journalism \\ in \\ Journalism and Communication
}

Carleton University

Ottawa, Ontario

(C) Michael Blanchfield 2015 


\begin{abstract}
Since coming to power in 2006, Prime Minister Stephen Harper has changed how Canada views the world, and how the world views Canada. This is evident through Canada's strained relations with the United Nations. He has shown disdain for the UN treaty process, including the Arms Trade Treaty, the Convention to Combat Desertification, and the Convention on Cluster Munitions. He used the UN umbrella to court support for his Maternal, Newborn Child Health initiatives, masking an overall cut in development spending. The UN has served as his government's main battleground to bring Canada closer to Israel than before.

A combination of political ideology and domestic political necessity lies behind this new foreign policy direction. That has meant smashing the brand of past Liberal governments and crafting policies that can appeal to Harper's core base, while attempting to attract other more mainstream supporters.
\end{abstract}




\section{Acknowledgements}

I returned to Carleton University to study journalism 26 years after getting my undergraduate degree so that I would be forced to write something resembling this. So to my professors and fellow students, who inspired me in different ways, my sincere thanks. A special thanks to Klaus Pohle, for a great title, so casually suggested over a modest lunch. I would not have been able to do this without any of you.

Since coming to Parliament Hill in 1998 to cover defence and then foreign affairs, I have worked in some powerhouse news organizations, including my current one, The Canadian Press. Many, many talented colleagues have inspired me over the years, and still do. I will always hold a special place for those few editors - they know who they are - whose reassuring voices on a telephone far away helped me do my job in dangerous places.

I owe special debt to my thesis adviser, Professor Randy Boswell. I first met Randy when we were both reporters at the Ottawa Citizen, and I know him to be a talented writer, storyteller and a true student of history. I thank him for his hard work and painstaking attention to detail, miniscule and profound. His rigorous intellect and passion for history and journalism have infused this work.

Finally, there is my immediate and extended family. I tried to get this done as quickly, efficiently and unobtrusively as possible. But I didn't, so my sincere apologies.

This is for Kathy, my loving wife, and Clara, our wonderful daughter - two people who really know how to get along in this crazy world. 


\section{Table of Contents}

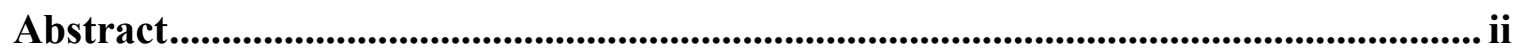

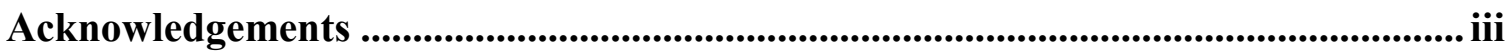

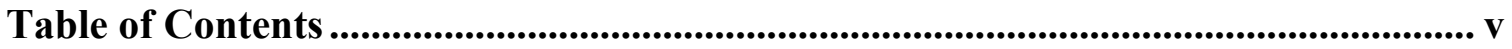

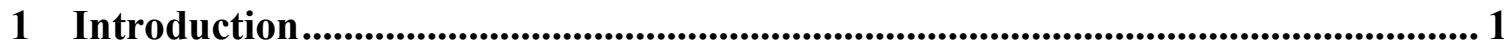

2 Chapter One: Canada and Harper - Finding their way in the world ................. 9

3 Chapter Two: Stormy Relations with the United Nations ................................. 46

4 Chapter Three: Saving Mothers, Children and Dollars...................................... 78

5 Chapter Four: Cluster Bombs ................................................................................... 106

6 Chapter Five: Israel and the Middle East ................................................ 132

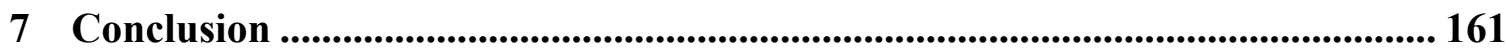

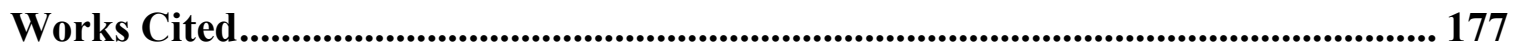




\section{Introduction}

July 12, 2006. Stephen Harper's government jetliner is almost wheels-up from Ottawa, bound for Europe, carrying the prime minister on his first extensive international trip since finally becoming prime minister a few months earlier. He will meet in London first with his seasoned counterpart, Tony Blair, and then go on to his first major international summit, the G8 in St. Petersburg, Russia, the hometown of Vladimir Putin, before a final planned stop in France. As Harper's plane prepares to taxi down a runway in Ottawa, the first reports emerge that Israeli warplanes are ripping up the tarmac of Beirut international airport. The attack is retaliation for the Hezbollah kidnapping of two Israeli soldiers — a brazen cross-border incursion into the Jewish state's territory by the militant group - marking the start of what will be a short, nasty summer war. France and Russia in particular — and later in the day, the European Union — denounce Israel's massive bombardment of the Lebanon-based Hezbollah as a "disproportionate" response to the kidnapping. (Knowlton)

Once airborne from Ottawa, I speak separately with three of Harper's communications staff as they circulate the rear aisles of the prime minister's plane. I urge them to bring him to the back of the cabin to address the journalists travelling with him about these fast-moving international developments. Employed by the Ottawa Citizen, I'm seated near the back of the Airbus jet liner, with more than a dozen national journalists, paying to travel on the prime minister's plane for his first big trip. In addition to a dozen reporters, photographers and television specialists, a larger than usual contingent of columnists from The Globe and Mail, Le Devoir, and the Toronto Star are also in tow. The extra turnout is understandable: there is plenty of curiosity about 
Harper's first major overseas trip — a major multilateral summit, and two stops in the capitals of Canada's two closest European allies. Harper doesn't have a lot of international experience, and there wasn't much foreign policy talk in the election campaign that brought him to power earlier in the year.

Eventually Harper emerges from the front of the plane and finds his way to us, pausing in an aisle as we crane over the seats to get close to him. He has removed his contact lenses in favour of wire-rimmed glasses. He looks me in the eye, and I ask him if he thinks Israel has acted in a disproportionate manner as the leaders of France and Russia, for instance, were saying just hours earlier. He speaks for three minutes in all, gives his answers, and departs. We all drop back into our seats, don our headphones and start transcribing. Harper's words will be widely reported hours later when his plane touches down in London.

These comments will represent his first line in the sand to distinguish Canada's position in the world under his leadership. Harper calls the massive Israeli bombardment after the kidnapping of its soldiers a "measured response." (Blanchfield "Harper stands")

Harper's comment marks the beginning of what has been a nearly decade-long discussion about how he sees the world — and what this means for Canada's place in it. From that moment on, there develops an overwhelming sense that something has changed in Canadian foreign policy. It's not that previous Liberal and Progressive Conservative governments weren't pro-Israeli. It's just that Harper's characterization immediately struck many as taking sides in the decades-old, intractable Israeli-Palestinian conflict. It also marked the beginning of a discussion — one that continues to this day — about 
whether Harper has pushed the country's foreign policy too far in one direction, and what this has meant for Canada's reputation in the world.

One of Canada's former Progressive Conservative foreign ministers and prime ministers doesn't like where Harper is taking the country. Joe Clark writes in his recent book that Harper's "fierce commitment to Israel also guides Canadian policy on much broader international issues. For example, the Harper government's hostility towards the United Nations is framed regularly in the context of solidarity with Israel." (84)

Fast forward to June 2011. Harper is delivering a speech to his party faithful at downtown Ottawa's gleaming new convention centre. It is one month after he has finally vanquished the Liberals — reducing the party to third-place status behind the NDP and won his first majority government. Five years after becoming prime minster, his foreign policy outlook is becoming more sharply focused. On this day, Harper draws a second, definitive line in the sand. He declares that under his watch Canada will "no longer just go along and get along with everyone else's agenda. It is no longer to please every dictator with a vote at the United Nations. And I confess that I don't know why past attempts to do so were ever thought to be in Canada's national interest." (Harper 2011b) That declaration will become an oft-repeated mantra that will be faithfully adopted by his new Foreign Affairs Minister John Baird, Canada's top diplomat from May 2011 until his abrupt resignation in February 2015.

Harper's post-election moment of celebration comes after a less auspicious occasion. In October 2010, the prime minister presided over one of the country's most embarrassing moments in the international arena — Canada's historic, first-ever loss of a vote for a temporary seat on the United Nations Security Council. But at the Conservative 
event in Ottawa, Harper is moving on. In drawing this second line in the sand, he is marking a fundamental separation with past Canadian foreign policy. Deciding not to "go along" has become the overriding rule of Canadian foreign policy since that moment four years ago. It represents a repudiation of Canada's time honoured practice of multilateral engagement, most notably with the UN. This is important because how Canada behaves towards the UN is a significant measure of how it gets along in the world as a whole. That's the view of Louise Frechette, a former Canadian ambassador to the UN, and the first deputy secretary general of the UN, a post created in 1997 and one that she would hold for eight years: "Our policy towards the UN cannot be separated from our foreign policy as a whole. The perception that member states have of us and the influence we can have over UN decisions depend as much on what we do outside the organization as what we do in it." (Frechette 273)

Stephen Harper's foreign policy has been transformative: it has changed how Canada views the world, and how the world views Canada. Harper has moved Canada away from the classic liberal internationalist approach to global affairs, one that emphasized multilateral cooperation within the many international clubs Canada has joined since the end of the Second World War, most notably the United Nations. One of the main ways in which a country interacts with the world is through its multilateral engagements - how it gets along in the big international pool of organizations, the umbrella groups for various configurations of countries. And the biggest multilateral organization, love it or hate it, is the United Nations.

Fen Hampson, one of Canada's leading international affairs experts, told me recently, "you can pick any elite diplomat you want to make a case for or against the 
government." (Blanchfield "Baloney Meter") Hampson urged the use of "metrics" such as the very large, annual international $\mathrm{BBC}$ poll that measures the likeability of various countries in order to measure the impact of the Harper government's impact on foreign affairs. (Ibid)

The metric in this study is the United Nations. Measuring how we have been getting along in the world's largest multilateral club tells us a lot about where we are going under the Harper government, and why. That means I won't be writing about the Harper government's trade policy, including its pursuit of free trade with Europe and in Asia, or the environment and climate change — notwithstanding Canada's groundbreaking dumping of the Kyoto Protocol - because this is for the most part already the subject of other voluminous analysis. Nor will this study explore Canada's Arctic agenda, which — like the vast region over which the prime minister wishes to exert Canadian sovereignty — is simply too large a topic, and one that deserves its own separate analysis.

The decision to focus on the UN is also based on 17 years of covering Canadian foreign policy for three different national news organizations - at home in Ottawa, travelling with three prime ministers on their airplanes, and setting off on my own to the front lines of wars in Afghanistan and Iraq, or to cover forgotten stories in Asia and Africa. On those less official wanderings, more often than not I would find a UN shingle hanging at the end of some desolate dirt road, leading to an office populated by wellintentioned people with deep roots in the country, trying to make it better. More relevant perhaps, Canadian taxpayers dollars were helping foot their bill. Canada remains the 
UN's seventh largest donor. But you might not realize that from what the current government says about the world's most important governing body.

As the prime minister has said, and John Baird, his longest-serving foreign minister, would often repeat, Canada isn't interested in going along for the sake of simply getting along in the international arena. Its robust, unwavering support of Israel, often displayed at the UN General Assembly, is a prime example. This has upset many, who see it as a betrayal of a perceived tradition of Canadian fair-mindedness on the international stage.

Former Liberal prime minister Louis St. Laurent, back when he was Mackenzie King's external affairs minister, gave the first major foreign policy speech by a Canadian politician that tried to define our place in the world. In the 1947 Gray Lecture, delivered in Toronto, St. Laurent said Canada's future prosperity was tightly tied to getting along in the UN. "If there is one conclusion that our common experience has led us to accept," St. Laurent tells his Toronto audience, "it is that security for this country lies in the development of a firm structure of international organization." (St. Laurent) It's the same message the former Progressive Conservative prime minister Brian Mulroney would deliver to the UN General Assembly 38 years later: "History shows the solitary pursuit of self-interest outside the framework of broader international cooperation is never enough to increase our freedom, safeguard our security, or improve our standard of living." (Qtd. in Keating 118) Yet, despite such historical declarations supporters of the present government say it was high time for a re-evaluation of Canada's global engagement, especially with an increasingly ineffective UN. 
So why has Stephen Harper deviated from the longstanding cross-party consensus of how Canada should govern itself outside its borders? In part, Harper is driven by a conservative ideology, one that was forged in the long years that led to the creation of a new conservative movement in Canada that — after much toil and anguish — would eventually unseat the ruling Liberals. The other driver of Harper's worldview is much more straightforward: it is to perpetuate his party's power. These two factors have, for the most part, resulted in a much more conservative stamp on Canada, both domestically and internationally.

This lies at the heart of the government's disdain for the UN treaty making process - its indifference to an Arms Trade Treaty, the Convention to Combat Desertification, and the Convention on Cluster Munitions. It also explains why Harper has, at the same time, strategically embraced the UN when convenient, to lend legitimacy to his main foreign aid initiative, improving the health of women and children in poor countries. Both stances appeal to Harper's conservative political base and thus play to his core domestic political imperative: getting re-elected.

Harper has staked out new ground for Canada in international multilateral diplomacy, and this is evident in relations with the United Nations. Canada is no longer an honest broker or helpful fixer, as many experts would suggest is the country's wellearned reputation internationally. The notion of Canada being some sort of well intentioned, all around reliable international good guy may be rooted as much in myth as in fact. Were we ever really that guy? At one time, it can be said, we certainly tried to be — motived by the very recent loss of 42,000 young citizens on the battlefields of Europe 
after the world's deadliest war in 1945, when St. Laurent first laid down the marker that it was better to get along than not.

Now, under Harper, Canada has become a different sort of global citizen, one that occupies a new, unfamiliar position for this country — the odd man out. 


\section{Chapter One: Canada and Harper — Finding their way in the world}

January 1947. More than 2,000 people are overflowing downtown Toronto's

Convocation Hall to hear a speech from their new secretary of state for external affairs, Louis St. Laurent. The hall is packed with university dignitaries, including Dr. Sidney Smith, who will a decade later become the external affairs minister in the Progressive Conservative government of John Diefenbaker that will eventually unseat the Liberals after 22 uninterrupted years in power. (Chapnick)

But that moment, which will mark the end of St. Laurent's own decade as prime minister, is still 10 years in the future on January 13, 1947. The chords of an organ cut the air, leading the crowd into "O Canada" sung in both French and English. Tape recorders are rolling so that the evening's address will eventually be heard in Great Britain. (Ibid) This is the first of what will become an annual lecture established by George Leishman Gray to honour the memories of his two sons, Duncan and John, who died during the war years. (Ibid)

"The first general principle upon which I think we are agreed is that our external policies shall not destroy our unity," St. Laurent tells the assembled gathering. (St. Laurent) "This consideration applies not only to the two main cultural groups in our country. It applies equally to sectionalism of any kind. We dare not fashion a policy which is based on the particular interests of any economic group, of any class or of any section in this country." (Ibid) Canada, says St. Laurent, "will prosper only as we maintain this principle, for a disunited Canada will be a powerless one.” (Ibid) St. Laurent also makes clear that Canada's future prosperity in the aftermath of the war is quite simply — to get along in the emerging international order, what he calls "the rule 
of law among states." (Ibid) Canadians, he says, unanimously support the work of international tribunals and courts of arbitration:

The growth in this country of a sense of political responsibility on an international scale has perhaps been less rapid than some of us would like. It has nevertheless been a perceptible growth: and again and again on the major questions of participation in international organization, both in peace and war, we have taken our decision to be present. If there is one conclusion that our common experience has led us to accept, it is that security for this country lies in the development of a firm structure of international organization. (Ibid)

St. Laurent's historic 1947 Gray Lecture at the University of Toronto laid the foundation of Canada's commitment to a multilateral worldview for decades to come. It has been the subject of extensive scholarly analysis, and as Royal Military College professor Adam Chapnick concluded, St. Laurent had one important message: "Foreign policy was unique; it was not the place for electioneering or partisan disputes." (2007) St. Laurent realized that Canadians may disagree on aspects of foreign policy but they must resolve those differences of opinion internally. "International relations were too important to become politicized, and Canadians had duties that extended beyond their immediate self-interest," Chapnick said. (Ibid) As political scientists David Dewitt and John Kirton have also observed, St. Laurent was making the point that "foreign policy must be discussed inside and outside Parliament without becoming a matter of partisan controversy among political parties." (49) St. Laurent saw value in getting along with global partners as he "vigorously defended the need to develop new international 
institutions," including the UN. (Ibid)

St. Laurent was adopting a very contemporary notion of foreign policy that was taking root at that time. In 1947, the Republican U.S. Senator Arthur H. Vandenberg, chair of the Foreign Relations Committee, gave his Democratic President Harry S. Truman some rousing bipartisan support as the U.S. was in the throes of helping to create the new NATO alliance. "We must stop partisan politics at the water's edge," Vandenberg declared, establishing the so-called "water's edge principle" that internal domestic politics should be kept at home, and out of international affairs. (Lieber)

Long before Stephen Harper became prime minister, Canada's international relations were about getting along with other countries, one way or another, especially in the United Nations - even if that meant being disillusioned or frustrated by the organization itself. Tom Keating, one of Canada's leading historians on multilateralism, said that as early as 1943, the Department of External Affairs, as it was then known, was determined to "secure the peace and win a place for Canada in the council of nations." (17) John Holmes, one of Canada's most influential diplomats from this era, offered one of the best explanations of the practical value of the UN to Canada, and why multilateralism mattered. It was a simple notion that holds to this day: Canada is a small country that can't defend itself, so it needs allies. Holmes said there was "nothing particularly high-minded" about a country adopting a strongly internationalist policy when that country "obviously cannot protect its people and its interest except in collaboration with others." (2)

Canada arrived at the 1945 conference in San Francisco that ultimately created the UN with two competing, but not mutually exclusive goals: avoid being subsumed by the 
interests of the four great superpowers of the time (the United States, the United Kingdom, Russia and China, minus the fifth member of the permanent Security Council, France) while finding a way to make this new organization a success. (Keating 26) Canada joined with Australia to oppose the veto powers that these permanent members were seeking, but they ultimately failed, and had to settle for some modest changes and some additional powers on economic and social issues. (Riddell-Dixon) As the historian Chapnick wrote: "The smaller states, including Canada, accepted these conditions and were fully aware of their implications. They understood that the future peace of the world depended on keeping the Great Powers engaged and interacting ... The Canadian government took the correct approach in 1945 by publicly accepting the hopelessness of the Security Council debate and eventually diverting some of its best negotiators to issues that presented better opportunities to make a genuine difference." (2006)

Canada wanted its voice heard in this new world body, especially when it came to how its soldiers might be used in future UN military operations. Canada and its fellow "middle powers" managed to infuse the new UN Charter with some provisions that reflected their interests in balancing the clout of the superpowers. (Keating 26) They worked for the inclusion of Article 23 in the UN Charter, which stated that due regard should be given to a state's contribution to peace and security when competing for a nonpermanent seat on the United Nations Security Council. (Dewitt and Kirton 21). Without referring specifically to that section, Harper invoked the core sentiment of that article some 65 years later when he stressed Canada's military contribution and losses in Afghanistan in a speech to the General Assembly in a final, though ultimately unsuccessful effort, to help Canada win a temporary two-year term on the Security 
Council. In 1945, the Canadian invention of peacekeeping was still more than a decade away, but the government successfully pushed for another key section, Article 44, which allowed non-members access to the Security Council to deliberate on how their troops might be used in UN enforcement missions. (Keating 27) However, Canada never succeeded in establishing a way that would ensure that non-superpower countries would get "near permanent" representation to the Security Council. (Ibid)

Despite that disappointment, the government remained committed to making the UN succeed. Escott Reid, a second secretary in external affairs, was one of three Canadian mandarins who played a major role in Canada's early UN engagement, along with fellow bureaucrat Hume Wrong and the up-and-coming diplomat Lester Pearson. Reid was disappointed by how Canada fared after the decisions in San Francisco, but he reinforced the notion that it was better to have a seat at the table than not. "One way in which Canada can help to remedy the weaknesses in the Security Council is by acting in the Security Council not in defence of the special interest of Canada but in defence of the interests of the United Nations as a whole," he wrote in a 1947 letter. (Qtd. in Keating 28) Five years earlier, as the Second World War still raged, Reid had written about the importance of multilateralism to Canada's future interests, saying "a small state like Canada would have an opportunity to exert a reasonable amount of influence in international politics at the cost of putting various aspects of its sovereignty into an international pool.” (Keating 20) For Reid, getting along in this emerging international organization was essential to Canada's interests.

Canada emerged as the third strongest Western power in the aftermath of the Second World War, but would have little time to enjoy this high-ranking status. (Holmes 
13) The decade-and-a-half that followed the UN's creation was a turbulent period, filled with highs and lows. Despite the formidable disappointments generated by the vetowielding Soviet Union, the federal government avoided direct criticism of the UN itself, and it never seriously questioned the value of working within the institution. Coming out of the Second World War, Canada's relative strength was due in large part to the decimation of Germany and Japan. The recovery and growth of other countries would soon bring Canada's international standing back down a few notches. Canada contributed to this course correction because it backed the drive to expand the UN's membership in the 1950s. It lobbied for the admission of 16 new members, in the face of strong U.S. opposition. (Keating 103)

The U.S. threatened to stop buying Canadian oil, but Paul Martin Sr., then Canada's health minister, brokered the deal that would see the number of UN members double by 1965, a breakthrough that kept the Soviet Union engaged with the UN and made it more reflective of the broader international community. (Riddell-Dixon) "In helping to break the UN membership impasse in 1955, Canada had fostered a dramatic change in the agenda of the UN," wrote Keating. (103) Such efforts reflected the core belief of Canada's political leaders and diplomats: that their country was better off with the UN, than without it. As Holmes said, it may be comprised "of all the brawling nations who cause all the troubles" but, "I cannot see any hope in a world without the UN." (62).

Canada agonized over making its debut run for the Security Council, stepping tentatively, but firmly, after some extremely careful consideration. Lester Pearson laid the groundwork, in the final years of his diplomatic life at the Department of External Affairs before he would enter politics in the fall of 1948 as external affairs minister. Pearson had 
strong views about "the likelihood of Arab-Jewish conflict after the British mandate over Palestine came to an end.” (Hilliker and Barry 32) Pearson believed the territory should be divided into two states, one Arab and one Jewish, but Justice Minister J.L. Ilsley, head of the Canadian delegation at the General Assembly, disagreed. Pearson pushed for a working group on Palestine and supported the termination of the mandate on Aug. 1, 1948 and partition under UN supervision. (Ibid) None of this brought peace to the region but it was a key moment in the development of Canadian diplomacy at the UN. (Ibid) This was happening outside the Security Council because it was experiencing problems, essentially the deadlock involving the Soviet Union, and its veto, a development that was creating division back at External Affairs over the "wisdom of seeking election to a twoyear term as one of the non-permanent members." (Ibid) In Ottawa, senior mandarin Hume Wrong lobbied against running for the Council while diplomat John Holmes argued from London it would be good for morale. Holmes thought it was ineffective and would lead to a drain on the department, "though he did point out that a refusal to stand would further weaken the United Nations." (Ibid) Caught in the middle was Pearson, who was not overly enthusiastic, "but he feared that a decision not to seek election might be misinterpreted in Canada as a loss of faith in the organization and might prejudice chances for election in future years." (Ibid) In the end, Pearson recommended to St. Laurent that Canada should run. Cabinet approved the proposal in August. On Sept. 30, 1947, Canada was elected for 1948-49 along with Argentina, with each country winning 41 of a possible 57 of votes, easily defeating their rivals. (Globe/CP 1947) Afterwards, Justice Minister Ilsley, who cast the country's vote with Pearson at his side, said Canada was "deeply conscious of the new responsibilities" it now had. He said Canada believed 
the UN was the best way to secure peace and prosperity in the world. "If we are to enjoy the benefits of such an organization, we must accept its responsibilities. That we are prepared to do.” (Ibid)

This foundation of Canada's stance towards the UN, and the history of constructive participation that ensued, are significant on many levels. It sharply contrasts with the present Canadian government's don 't-go-along-to-get-along mantra, as does the notion that the Canadian government should place its self-interest second to the good of the UN as an institution. The one-month campaign in 1947 between deciding to run and actually winning a temporary seat on the Security Council was whiplash fast compared to the years' long, expensive campaigns that would be a feature of Security Council bids in the decades to come. Most of all, it spoke to Canada's high standing in the international community in the immediate post-war era, a counterpoint to the circumstances of its embarrassing loss at the UN in October 2010. In 1947, and five more times before the end of the $20^{\text {th }}$ century, Canada raised its hand for duty, and its international partners enthusiastically embraced it.

During its first major stint on the Security Council in 1948-49, Canada played a lead role in major conflicts far from its border. This term marked Canada's debut as a tangible contributor to global peace and stability. The country's first permanent ambassador to the UN, retired Gen. Andrew McNaughton, led the country's efforts and extended its influence into security matters in Central and South Asia. McNaughton played a role in the India-Pakistan dispute over Kashmir, and helped broker the birth of Indonesia, which would become the world's most populous Muslim country. The issues facing both areas may have been "remote from Canada geographically and from 
Canada's direct interests." (Spencer 118) But this area would not remain remote to Canada's interests in the century to follow, especially after the Sept. 11, 2001 terrorist attacks on the United States brought home the geopolitics of the Islamic world to Canadians. Canada's first stint on the Security Council was prophetic, and represented a significant early connection to its eventual 13-year military engagement in Afghanistan that would end in 2014. McNaughton was chair of the Security Council in February 1948 in just the second month of Canada's term. Throughout early 1948, McNaughton continued informal consultations with India and Pakistan, helping to co-author a resolution on the crisis that was passed on April 21 by the Council. It provided for the withdrawal of the Pakistani tribesmen and the reduction of Indian forces in Kashmir to the minimum required for "the maintenance of law and order." (Spencer 119) After much delay and difficulty, including opposition in India, a deal was reached on Jan. 1, 1949. McNaughton called it, "a most important and encouraging event in the history of the United Nations" and said its effects would extend far beyond India and Pakistan. (Spencer 120) By the early $21^{\text {st }}$ century, the still unstable Pakistan — surrounded by its enemy India on one side, and the volatile Afghanistan on the other - would see its tribal lands along its Afghan border become a safe haven for al-Qaida terrorists to attack Canadian troops and their western coalition allies inside Afghanistan.

Meanwhile, the four-year-old armed conflict between The Netherlands and the Indonesian Republic that started in 1945 had to be addressed. It would ultimately mark the beginning of the end of Dutch colonial rule in the Southeast Asian archipelago. On March 11, 1949, McNaughton proposed a conference to settle the dispute, which the Security Council approved less than two weeks later. Talks began in April and continued 
into November and December. On December 27, 1949, the Dutch formally transferred sovereignty, and Canada immediately recognized the new Indonesian Republic. (Spencer 122) McNaughton's grandson, retired Lt.-Gen. Andrew Leslie, recalled the contributions of his grandfather and his contemporaries towards establishing Canada's diplomatic footprint in new corners of the world. "He established very strong relationships with a whole host of people from the Americans, the Indonesians, the Chinese, to even the Russians," Leslie, now an Ottawa-area Liberal candidate for the 2015 federal election recently recalled. (Interview) "You had a confluence of remarkable men and women who saw themselves as the natural sort of interlocutor between some of the Americas and Russia and China.” (Ibid)

The principles laid out in St. Laurent's Gray lecture set the stage for what was to become Canada's most influential moment in international diplomacy. There are many lessons to be learned from Lester Pearson's Nobel Prize-winning efforts to find a solution to the Suez Crisis of 1956, but one is particularly relevant when considering those events in contrast with Stephen Harper's foreign policy pronouncements a half-century later. The struggle over the Suez Canal was a showcase example of Canada not always getting along with other countries — including with some its closest UN allies — yet staying the course, and working within the existing international system to make a difference. Canada butted heads with Britain, which along with France was secretly backing an Israeli attack on Egypt, after Gamal Abdul Nasser, its Soviet-leaning president, nationalized the Suez Canal. (Hillmer and Granatstein 194) Publicly, St. Laurent expressed "regret" that the British and French were planning the attack, but in private he was clearly angry at the Brits. (Ibid 195) Canada used the UN to push back against its old 
colonial rulers, Britain. This is what essentially gave Pearson, Canada's external affairs minister, the space to become the father of peacekeeping.

With the backing of U.S. President Dwight Eisenhower, who was deeply troubled by the actions of France and Britain, Pearson proposed that the French and British troops be transformed into a United Nations force. (Ibid) Pearson accomplished this with the close backing of St. Laurent, his prime minister, whom he considered "a very close friend" and who told him: "Do the right thing, and I'll back you." (Qtd. in Eayrs 26) A decade earlier, when he was still a diplomat, Pearson had sent a hand-written note to Gerry Riddell, the foreign service officer who drafted and revised St. Laurent's Gray Lecture. Somewhat prophetically, Pearson scrawled: "This, I think, very good stuff indeed — if the minister doesn't use it, I would like to put in a bid for it.” (Qtd. in Chapnick 2007)

Crucially, Pearson and St. Laurent also had the support of their political opponents. Official Opposition Leader John Diefenbaker wrote in his memoirs how, in 1956, he himself had proposed some kind of "an organization under the United Nations, a watching force, a presence between the Israeli and Arab forces" to help defuse the Suez Crisis. (280) It was Pearson, though, who would lay the groundwork for the creation of that very first UN peacekeeping force, which would earn him the Nobel Peace Prize in 1957. In the House of Commons debates on the peacekeeping deployment, Diefenbaker criticized St. Laurent for what he saw as a "bitter speech." (Ibid) Diefenbaker was staunchly pro-British, and was uncomfortable with Pearson butting heads with the Empire. But in the end, the Progressive Conservative opposition leader supported the 
Liberal government: "I endeavored then, as I always have on international affairs, to bring about non-partisan unity." (Ibid)

After Diefenbaker's Tories defeated the Liberals in 1957, he would also feel the pull of the UN and multilateralism over the course of his six years in power. He managed to topple the Liberals in part by using their conduct of the Suez Crisis to his domestic advantage. During his initial campaign he accused the St. Laurent government of not supporting "the mother country" because it was offside with Britain, a tactic that Keating observed was, "one of the rare instances in which bipartisanship broke down in Canada's internationalist foreign policy and it may have had some influence on the Liberals' fall from power in the 1957 federal election.” (41) But while the Liberals lost at home, they were big winners on the international stage with Pearson winning the Nobel Peace Prize that same year.

Once in power, Diefenbaker didn't rock the boat internationally. Though there was much speculation that Diefenbaker's new minority government might move Canada away from the UN, "Mr. Diefenbaker was clearly attracted by the United Nations and the opportunities it offered for taking up a position as a world statesman. In his speech to the General Assembly on September 23, he declared that the United Nations was the cornerstone of Canada's foreign policy." (Lloyd 132) In doing so, Diefenbaker was able to establish the principle of a non-partisan foreign policy in modern, post-war Canada. Diefenbaker's external affairs minister Howard Green, who replaced Sidney Smith after his sudden death on March 17, 1959, displayed great enthusiasm for Canada's accomplishments at the UN in a November 1959 television interview with the CBC. In his folksy manner, Green conveyed a sincere desire for Canada to make a significant 
contribution and find consensus during its time on the Council. He took pride in winning unanimous approval for a study of the harmful of effects of radiation. Asked by his interviewer, Charles Lynch of Southam News, whether this was a move to force an end to nuclear bomb tests, Green replied: "Well of course the bomb tests are one feature of the situation but there's radiation from many other causes and we want them tested." (CBC 1959)

In 1962, Diefenbaker used the United Nations as a foil against the United States to guide Canada's reaction to the Cuban missile crisis. Diefenbaker didn't get along with U.S. President John F. Kennedy, and he was skeptical of the threat of Soviet missiles in Cuba. (Burney \& Hampson 20) He wanted "irrefutable evidence" of Russian military installations in Cuba, and he urged Kennedy to call for UN inspectors to be sent to Cuba to verify. (Ibid) Some argue that Diefenbaker's personal loathing of the younger, more attractive American president may have clouded his judgment. (Ibid) Regardless, it was an example of Diefenbaker defaulting to the UN, and it had more in common with the stance taken by the Liberal government of Jean Chrétien in 2003 over Iraq than Stephen Harper's decision as opposition leader to support the U.S.-led invasion of Iraq. This is significant because Harper has cited Diefenbaker as a foreign policy influence, in what appears to be an attempt to downplay the influence of the Liberals in Canadian foreign policy over the decades. Yet there is much daylight between Harper and Diefenbaker.

Pierre Trudeau arrived in power in 1968 with a relatively jaundiced view of Canada's relations with the UN and multilateralism in general. In some ways, this makes Trudeau and Harper a pair of unlikely kindred political spirits. The preceding five years of Liberal rule from 1963 to 1968, made up of two successive minority governments led 
by Lester Pearson, who had succeeded St. Laurent as prime minister, had dulled the glow of the previous decade's Nobel Peace Prize, as well as the country's so-called golden era of diplomacy. Internationally, Pearson had some nasty battles with U.S. President Lyndon Johnson over the Vietnam War. At home, he waged a hard battle to give Canada its new Maple Leaf flag while Canada's enthusiasm for the UN waned and the country grew tired of its middle power status. (Keating 117) Out of that flowed Trudeau's notion of "interest-based" foreign policy. Trudeau immediately commissioned a foreign policy review that emphasized "national interests as the basis for policy calculation and the initiation of policies and programs" in foreign affairs. (Dewitt and Kirton 39) Trudeau wanted to jettison the "helpful fixer" image that Pearson had established — that of Canada as an altruistic, self-sacrificing nation always working for a greater global good. (Hillmer and Granatstein 250) In 1970, Trudeau delivered his review, Foreign Policy for Canadians, which emphasized a new, more self-interested direction. It said: "In essence, foreign policy is the product of the Government's progressive definition and pursuit of national aims and interests in the international environment. It is the extension abroad of national interests." (Qtd. in Hillmer and Granatstein 253) Trudeau's Canada-first approach to foreign policy was also tempered by a more altruistic foreign aid policy that recognized the need for Canada to accept its fair share of the responsibility to alleviate poverty in poor countries. Still, historian James Eayrs dismissed Trudeau's new approach to international affairs as dollar diplomacy and "foreign policy for beavers." (Ibid) But in many respects, Trudeau shared Harper's indifference towards the UN. Harper was harshly criticized for snubbing the UN General Assembly in 2009 for a photo-op at a Tim Hortons outlet, but Trudeau was equally dismissive at times. In 1970 , on the $25^{\text {th }}$ 
anniversary of UN's founding, Trudeau declined an invitation to address the General Assembly and lead off the debate marking the milestone, breaking with every other postwar prime minister. (Keating 106) Trudeau would wait until 1978 before addressing the UN at its Special Session on Disarmament. Keating viewed Trudeau's absence in 1970 as a reflection of the "new thinking that was guiding Canadian foreign policy with its greater emphasis on national interest and its denigration of the country's mediatory middle power roles." (Ibid) Still, Trudeau couldn't resist the pull of the UN, or give up entirely on multilateral diplomacy. "In practice, even a skeptic like Trudeau could not resist the pressures that were often placed on Canada to play intermediary roles in international disputes," wrote Keating. "Canadian diplomats and politicians had acquired a reputation that was not easily abandoned." (107)

For all of Trudeau's initial reticence towards the United Nations, he eventually found a reason to raise his voice in the world's premier international forum. Trudeau finally addressed the United Nations on May 26, 1978 and took aim at the nuclear arms that lay at the heart of the Cold War between the Soviet Union and the United States. Drawing on the expertise of diplomat Klaus Glodschlag, Trudeau called for a nuclear "suffocation" strategy, "a coherent set of measures, including the comprehensive test-ban treaty, an agreement to stop the flight testing of all new strategic delivery vehicles, an agreement to prohibit all production of fissionable material for weapons purposes, and an agreement to limit and reduce military spending on new strategic nuclear weapons systems." (English 377) Though some critics initially dismissed the speech, it mirrored the views of U.S. President Jimmy Carter, and the sprit of détente that was growing in the 1970s. (Ibid) A generation later, Lloyd Axworthy, who would go on to become foreign 
affairs minister in the 1990s after cutting his teeth in Trudeau's cabinet, wrote in his memoirs that, "Trudeau added a further element to the foreign affairs legacy established by Pearson.” (Axworthy 38) Axworthy saw Trudeau's nuclear activism — which included his swan song 1984 world peace mission — to be a "classic middle power stance" that showed Canada as an independent voice on the world stage that was not afraid to stand up to the more powerful countries. (Ibid) "This was defining a leading role for Canada in establishing norms of global behaviour and rules of law," wrote Axworthy. "It was a position that suited the growing maturity of Canada, and a lesson that needs to be built upon from generation to generation." (Axworthy 39) Paul Heinbecker, a speechwriter for Trudeau prior to becoming one Canada's most distinguished diplomats, said Trudeau never disliked the UN. "Trudeau's attitude was not that he hated the UN, but that if he didn't have something worth saying, he wasn't going to go," Heinbecker explained in an interview. "He, like Harper, didn't like people very much. And one of the reasons you go to New York is because all those other leaders are there."

Brian Mulroney actually revived Pearson-style multilateralism when he brought the Progressive Conservatives back to power in 1984, even though he moved Canada closer to the United States than any previous prime minister. Mulroney showed how Canada could balance two apparently competing foreign policy priorities — UN multilateralism and getting along with our massive southern neighbour. His government stressed the importance of multilateralism in his first Speech from the Throne in 1984, as he also emphasized how strengthening relations with the U.S. must be a priority. He firmly endorsed the UN in his first foreign policy review, which said that recent developments had "created a serious challenge to a principal vehicle of Canadian foreign 
policy, the world's multilateral agencies." (Qtd. in Keating 113) And it was in his address to the UN General Assembly in 1985 that Mulroney made clear his view that the "solitary pursuit of self-interest outside the framework of broader international cooperation is never enough to increase our freedom, safeguard our security, or improve our standard of living.” (Qtd. in Keating 118) That affirmation aligned the Mulroney Progressive Conservatives with the tradition of past Liberals governments. It was truly the flip side of Harper's mantra of recent years, of not standing with UN partners and objectives just to get along, to get along in the club of global nations.

Like the St. Laurent-Pearson Liberals with the Suez crisis in 1956, the Mulroney Progressive Conservatives in the 1980s used the UN to make their mark on the world with their campaign to fight South African apartheid. Mulroney, too, surrounded himself with some good help. He appointed former prime minister Joe Clark as his external affairs minister, and in a landmark demonstration of non-partisanship, he tapped New Democrat Stephen Lewis to be his UN ambassador. Together they led Canada's hard push for tough sanctions against South Africa's apartheid regime. They did this in the face of opposition from Canada's two closest allies, the U.S. and Britain. In the end, they persevered and helped turn the tide against the racist regime. Lewis became friends with Nelson Mandela, who survived 27 years as a political prisoner before becoming South Africa's first post-apartheid president. Lewis visited Mandela several times in retirement in South Africa between 2001 and 2009. As Lewis told me on the day Mandela died in December 2013, Brian Mulroney was one of Mandela's favorite topics of discussion. (Blanchfield "Moral leaders") "He had a tremendous affection and regard for our former prime minister, who did do a really major job in the work to overthrow apartheid and 
have Mandela released," Lewis said over the phone from Toronto's Pearson airport, about an hour before he was to begin his latest journey to South Africa. (Ibid)

In a separate interview 15 months later, Lewis described how — as a socialist — he was able to find common ground and serve a conservative prime minister. The relationship worked because he and Mulroney left their domestic partisan political beliefs at the water's edge.

"He made it clear to me I could have a strong voice and that there were times I could disagree with the government policy and he wouldn't have a cardiac arrest," Lewis recalled. "We worked well together and we had two things in common: one was the determination to overthrow apartheid; the other was to give as much as aid as possible to struggling African countries.”

Mulroney may have been famous for holding a grudge, for blacklisting people who had crossed him. But as Lewis recalled, that didn't extend to a robust and respectful political disagreement. "You could disagree fundamentally with Brian Mulroney and have a very good intellectual or verbal battle, and he wouldn't ostracize you," Lewis said, before turning our discussion from Canada's political past to its present. "You could disagree with Mulroney but you knew he was genuine. Harper is entirely political. Almost everything Harper does, every speech that's made, is so poisoned and calculated by opportunism and political manipulativeness. He is the ultimate Machiavelli." The Progressive Conservatives, like the Liberals before them, demonstrated how Canada could use the UN to make their country's voice heard in the world for a greater good, beyond our borders.

With the rise of the Chrétien Liberals, the "soft power" of the human security 
agenda became one of the signature foreign policy pursuits of the 1993- 2005 era. It formed the backbone of Canada's agenda during its sixth — and, so far, final — stint on the UN Security Council in 1999-2000. The era was also marked by Prime Minister Jean Chrétien's firm decision — heavily challenged by the Conservative opposition led by Stephen Harper — to firmly align Canada with the UN in 2003, at a critical juncture in international affairs. Chrétien ultimately decided that Canada would not support the U.S.led invasion of Iraq without the Security Council's approval. The UN proved instrumental in giving the Liberals the moral authority to oppose its top ally, the United States, under Republican president George W. Bush. Indeed, the UN empowered two of America's major allies on the Security Council — Germany and France — to just say no to joining the small invading coalition, which also included Britain. As Canadian author and professor Jennifer Welsh wrote in her book on Canada's way forward in the $21^{\text {st }}$ century: "Countries such as Canada, traditional backers of the UN approach to collective security, breathed a sigh of relief: we did not have to choose between supporting the United States and supporting multilateralism.”(16)

Canada had committed heavily to the UN during the most recent era of Liberal rule. After a high-level campaign that lasted half a decade, the Security Council stint of 1999-2000 gave Canada a forum to pursue its human security agenda, as espoused by Foreign Affairs Minister Lloyd Axworthy. Canada assumed a leading role in the creation of three new international instruments: the passage of the Ottawa Convention of 1997 that banned anti-personnel landmines, the treaty that paved the way for the creation of the International Criminal Court in 1998 and the UN's later endorsement of the Responsibility to Protect doctrine (R2P) in 2005. Axworthy brought together the 
international coalition of non-governmental agencies and civil society groups that pushed for the landmines treaty, a movement destined to be recognized with a Nobel Peace Prize. In October 1996, Ottawa's old downtown train station, a converted conference centre, was the scene of a large international meeting -50 international governments, several UN agencies, the International Committee of the Red Cross and many other NGOs kicking off what became known as the Ottawa Process. As the meeting closed, Axworthy threw down a gauntlet to those assembled: come back to Ottawa by the end of 1997 to sign a treaty. On Dec. 3, 1997, they did, (Tomlin et al. 242) just weeks after the Nobel Prize had been awarded to U.S. activist and Axworthy collaborator Jody Williams and her International Campaign to Ban Landmines.

They were never able to persuade the United States to join, and still haven't. But the treaty did win the support of then-U.S. President Bill Clinton. (Tomlin et al. 235) Some 17 years later, Axworthy remained optimistic that the Americans would eventually join because of U.S. Secretary of State John Kerry's comment in an op-ed for USA Today that his country would work to "find ways" to accede to it. (Blanchfield "Kerry musing")

Canada also played a leading role in the events that led to the signing of the Rome Treaty on July 17, 1998, which created the International Criminal Court. Though it's closely associated with Axworthy, the ICC had its roots in the last days of Mulroney's Progressive Conservative government when then-external affairs Minister Barbara McDougall was emotionally moved by the conditions she saw while visiting Bosnian refugee camps. That alone speaks volumes to the non-partisan nature of the initiative. (Tomlin et al. 243) Several Canadians, such as Philippe Kirsch, who chaired the Rome conference that led to the treaty, played key roles in the creation of the ICC. (Tomlin et 
al. 249) Canada provided financial support to the UN Trust Fund so that poor countries could take part in the negotiations and to non-governmental organizations in developing countries "to mobilize public support for the ICC." (Ibid)

Canada also led the drive for the UN to adopt the Responsibility to Protect doctrine, which provided rules for when the world could intervene within the borders of a sovereign state to prevent its leaders from harming their own people. The lofty ideals of R2P — adopted by the UN in 2005 — have never truly been realized; the world's inaction in response to the four-year-old Syrian civil war that has left hundreds of thousands dead and forced millions from their homes is a stain on the original concept. However, Axworthy helped get the R2P ball rolling in his final year in politics. In 1999, NATO decided to lead the international mission to bomb the former Yugoslavia to protect persecuted ethnic Albanians in its Kosovo province, without UN approval. The UN Security Council was blocked by the veto of Russia and China, so after some agonizing debate within its own Foreign Affairs Department, Canada joined the NATOled mission that was operating outside of UN authority. (Tomlin et al. 254) In the end, after a robust military intervention, a civilian population was protected — laying the foundation for the UN's Responsibility to Protect. Canada may have operated outside the UN system in that instance, but the action forced the multilateral system to evolve. While Canada may have stepped outside the UN system briefly, it immediately returned to the fold in the spirit of trying to improve it.

Axworthy exploded at the Security Council in 1999, saying that as an "emasculated" and "obsolescent" institution, it was powerless to halt the carnage of Kosovo, but he later backed off from the criticism. (Blanchfield "Backs off") Yes, the 
Liberals could — and occasionally did — lose patience with the UN. But unlike the Harper government, they continued to work within the UN system, funding the International Commission on Intervention and State Sovereignty, helping select its members and organizing meetings, all in an attempt to find a solution - a new set of rules — that would prevent a repeat of the 1990s' genocides in Rwanda and Bosnia and the UN's failure to act in Kosovo. R2P went through various rewrites before it was adopted at the 2005 UN World Summit.

The Axworthy soft power agenda was not universally revered, including at home in Canada. International affairs expert Fen Hampson, head of the global security program at Centre of International Governance Innovation in Waterloo, Ont., has said that while human security had its virtues, it "could be had on the cheap," compared to the high price of peacekeeping. "Pulpit diplomacy, as critics dubbed it, did not ask Canadians to open their wallets when the collection plate got passed around." (Hampson 2000) Hampson noted that under Mulroney, Canada also pushed hard for human rights abroad, particularly for the sanctions that helped topple South Africa's apartheid regime. And he pointed out that Axworthy's human security agenda was "largely derivative," drawing on Harvard academic Joseph Nye's concept of "soft power" and the 1994 Human Development Report by the United Nations Development Programme. (Ibid) Hampson still conceded that “Axworthy's chief legacy, however, is that he raised Canada's profile internationally — and it is indeed Canada's name that is associated with landmines and various other human security initiatives, and not so much Mr. Axworthy himself." (Ibid) Whether for or against them, the last period of Liberal rule in Canada prior to Harper's win in 2006 nonetheless left an indelible impression on Canadian foreign 
policy. It was that firm policy footprint that Stephen Harper was determined to erase, like a high tide wave crashing a beach. When he came to power, Harper wanted nothing more to do with the Liberal party's foreign policy legacy — from St. Laurent and Pearson to Chrétien and Axworthy — and so he set out to remake Canadian foreign policy into something more to his liking.

$* * *$

October 1987. A young, disillusioned Stephen Harper is in Winnipeg. He’s just quit his job as a staffer with the Progressive Conservatives. He is addressing a seminal meeting of the new Reform party movement. It is early days in the grassroots movement, and among the manifestos and policy documents circulating at the Winnipeg gathering, there's little resembling a vision of how Reform views the world outside Canada's borders. Harper has aligned himself with a heady young group of Western Canadians, determined to politically remake the country. The group's ideological and practical considerations were inseparable, and revolved around one thing: winning power, and holding it. At this point, this sense of Western Canadian alienation — summed up in the rallying cry "The West Wants In" — was all about a fight for power and how to redefine the country from within. As Harper himself ascended the ranks of the newly emerging "Canadian right" — a formulation of conservatism borrowed from U.S. politics - he would win a seat in Parliament in 1993. But he resigned in 1997 out of despair for Reform's chances of ever winning power, only to return in 2002, to lead a reconstituted conservative movement for which the goal of toppling the Chrétien-Martin Liberals became all defining. It culminated in a tumultuous fight for power between 2001 and 2006, when Harper finally became prime minister. There were many battles before 
Harper would firmly grip the levers of government on Jan. 23, 2006. He had to win the leadership of both the Canadian Alliance in 2002 - becoming Official Opposition leader — and then the newly merged Conservative party in March 2004; then he failed to unseat the Liberals in the general election of June 28, 2004 that spawned the minority Paul Martin government and he failed to bring down that minority government in May 2005. (Flanagan 3) All along that hard road, Harper continued to ruminate, write and make speeches, occasionally dropping hints as to where his foreign policy might take Canada one day.

Prior to 2006, Harper showed little interest in international affairs. When he touched on the topic, his views were driven by one sacrosanct principle: creating a unified right-wing political alternative that would unseat the Liberals as the natural governing party of Canada. Harper may have had little initial foreign policy experience, but he became emboldened as time passed. Three major influences shaped Harper's thinking on international affairs in the two decades before he won power. First, there was the domestic political landscape, which in Harper's view would allow the Liberals to govern in perpetuity because of a divided right. (Harper \& Flanagan 1996) In writings that spanned the late 1980 s to the early 2000 s, from the creation and demise of Reform and the Canadian Alliance, to the birth of the new Conservative Party of Canada, Harper hashed out what was essentially a manifesto-in-progress, with the single purpose of defining a conservative alternative to the Liberals for Canadian voters. Occasionally, this coalescing vision would touch on foreign policy, which was mostly about how the Liberals were getting it wrong. Secondly, recent history had helped form his Manichean view of the world - a black-and-white, right-and-wrong perspective. He was influenced 
by readings about Soviet communism and Nazi fascism during the 1930s. He drew lessons from the successes of British and American conservatives under Margaret Thatcher and Ronald Reagan in the 1980s, as well as Australia's John Howard in the 1990s and early 2000s. Thirdly, the political debates that led to Canada's refusal to participate in the U.S.-led invasion of Iraq in 2003 forced Harper to stake out his most definitive foreign policy positions to that point: a stridently anti-Liberal, anti-UN worldview.

In a 1996 Next City Magazine article co-written with University of Calgary political scientist Tom Flanagan, Harper laid out the stark reality facing conservatives: the Liberals had won 14 of 22 elections since 1921. Harper bemoaned the fractured opposition that he believed would keep conservatives from power; his assessment was as dire, and his desire for power was palpable. "In the last 50 years, the only Progressive Conservative majority governments were John Diefenbaker's in 1958 and Brian Mulroney's in 1984 and 1988." (Harper \& Flanagan 1996) Harper's political timeline is illuminating for another reason: it shows how the Liberals were able to dominate Canadian foreign policy in the post-war era. Rarely out of power, they became Canada's default political interlocutor with the world. Yet Mulroney and Diefenbaker for the most part rejected a partisan approach and generally followed the flow of this tide, accepting it as Canadian, and not owned by a particular political party. Harper appeared intent on redefining Canadian foreign policy by making a clear break with multilateralist, Pearsonian, small-L liberal internationalism. Demolishing the sacred cows of all things Liberal meant a rewrite of the Canadian foreign policy playbook, or as Harper saw it, the Liberal playbook. 
Prior to winning power, Harper didn't spend a lot of time delving into substantive foreign policy discussions. But when he did, it was clear he saw a need to change Canada's place in the world because, in his view, the Liberals had made a big mess of things. "The Liberal party should be understood not as a centre-left party, like the American Democrats or British Labour, alternating in office with a centre-right alternative," he wrote with Flanagan in Next City. (Ibid) "Rather it is a true centre party, comparable to the Christian Democrats in Italy, the Liberal Democrats in Japan, and Congress in India, standing for nothing very definitive but prevailing against a splintered opposition.” (Ibid)

As Harper delved into the machinations of the ruling coalitions of Germany, France and Australia, it all came back to a question of domestic political tactics - how lessons learned from abroad might be drawn to help conservatives win power in Canada one day. "Each of these countries uses something other than first-past-the-post voting," Harper lamented, hinting at a momentary interest in electoral reform that was later expunged from his political agenda. "Both the Reform party and the Bloc Quebecois, or even the PCs, could go on for decades without ever becoming national parties.” (Ibid)

In a January 29, 1997, interview on CBC's The National, Harper was asked about the 1989 promise Canada made to the United Nations to end child poverty by 2000 in Canada. His answer did not acknowledge the UN, or engage any kind of meaningful discussion on multilateralism. He called the resolution adopted by Parliament "the highwater mark of political stupidity in this country." (Qtd. in Johnson 259) He ridiculed the notion that "the Parliament of Canada could just declare that child poverty was going to be outlawed and that it was going to throw enough money at it, to do it." (Ibid) $\mathrm{He}$ 
equated international aid with domestic welfare programs. "I think taxpayers feel we are throwing lots of money at social programs. The question is whether they're effective," he continued. (Ibid) "And I think to do that, you have to start to examine the incentive structure of those social programs." (Ibid)

It's one of Harper's earliest known pronouncements on how he regarded international aid, a key aspect of foreign policy. It came 13 years before he would in fact start throwing some big money — billions of dollars — at his signature foreign aid initiative to help pregnant women and their children in the developing world. At the same time, Harper would freeze and cut overall foreign aid spending, leaving it well below UN targets. That policy made clear that domestic political considerations trumped any sense of international obligation. To Harper, the interest of the Canadian taxpayer was paramount. He was determined to show how targeted aid dollars could have an immediate measurable outcome versus funding the core programming of larger multilateral organizations, many of the UN institutions, which allowed them to fund a broad array of development projects.

In a May 28, 2002 speech in the House of Commons, his first after becoming opposition leader, Harper articulated his top foreign policy priority: having a strong relationship with the United States. He did this through an attack on Jean Chrétien's handling of relations with the United States. He criticized Chrétien for lack of progress on resolving the softwood lumber dispute, getting restrictions lifted on agricultural imports and neglecting the military. (Qtd. in Johnson 315) "For nine years the government has systematically neglected the Canadian Forces and undermined our ability to contribute to peace enforcement and even peacekeeping operations, including recently 
our premature withdrawal from Afghanistan," he added. (Qtd. in Johnson 316) He praised Brian Mulroney because "he understands a fundamental truth. He understood that mature and intelligent Canadian leaders must share the following perspective: the United States is our closest neighbour, our best ally, our biggest customer, and our most consistent friend." (Ibid) However, Harper conveniently ignored the other prong of Mulroney's foreign policy: support of the UN.

In a Dec. 14, 2004 speech to the Canadian Club in Ottawa, Harper attempted to burnish his foreign affairs bona fides. He quoted Reform founder Preston Manning intermittently and Mulroney extensively "to bring a historical imprint to the party's foreign affairs stance," wrote one of Harper's early biographers, Lloyd Mackey. (173) He presented some fundamental principles. "For Conservatives, the defining element of our approach to foreign policy is to better advance the national interest, including the security of Canadian territory; the economic prosperity of the Canadian people; and the values of democracy, freedom and compassion that define the Canadian nation." It was an approach the echoed Trudeau's initial reticence towards the UN, but showed no trace of the Liberal leader's later embrace of the UN in pursuit of his anti-nuclear agenda. He referenced Manning on the need to "think big" in terms of relations with the United States. (Ibid) This pro-U.S. stance was common throughout Harper's pre-election years. He extolled the need to move closer to the U.S. and lambasted the frequent Americanbashing of the Liberals. In the speech, Harper also suggested that he had "inherited" a proud conservative tradition of "constructive internationalism." (Mackey 174) Harper touted Mulroney's record on development assistance and international security, and how he led the fight against apartheid in South Africa, "disagreeing with the United States 
without being disagreeable, without in any way jeopardizing our bilateral relationship." (Ibid) In evoking Mulroney and Diefenbaker, Harper was attempting to "provide some gravitas and historical context to party policy on foreign affairs, since 'a government-inwaiting' gets asked some of its most serious questions in that field," wrote Mackey. (Ibid) But that didn't translate into substance by the time the party crafted its 46-page platform for the 2006 federal election: foreign policy consisted of three sentences and less than 200 words. Despite the brevity, it still managed to take shots at the Liberals: "Too often, Liberal foreign policy has compromised democratic principles to appease dictators, sometimes for the sake of narrow business interests. Foreign aid has been used for political purposes, not to ensure genuine development." (Qtd. in Nossal 2013, 24) It was a vague policy plank, providing no specifics of how the Liberals tried to achieve their political goals through foreign aid, and little detail of how the Conservatives would do this better.

The behavior of dictators as well as some of the more fierce democratic partisans of the 20th century also influenced the young Stephen Harper. He was drawn to the 1930s of pre-war Europe, when the Depression raged and the Soviet Union's communism flourished, but also to the 1980s, the Thatcher and Reagan eras that entrenched conservative power in Britain and the U.S. Harper was deeply interested, as well, in how John Howard consolidated his hold on power in Australia. Author William Johnson, in a biography of the Conservative leader published before he won power, described how as a thoughtful, introspective young man in his twenties, Harper was drawn to Ian Hunter's biography of Malcolm Muggeridge, the Manchester Guardian reporter who covered the Ukraine famine imposed by Josef Stalin in the 1930s. (45) Millions starved as Stalin 
exported the region's grain to speed the industrialization of the Soviet Union.

Muggeridge undertook an unauthorized reporting trip, smuggling his reports out in a diplomatic pouch. (Ibid) Clearly, this was a seminal text in the formation of Harper's worldview, shaping his anti-communist, black-and-white view of the world. Two years after he became prime minister, Harper made Canada one of the first countries to declare the 1932-33 Ukrainian famine, known as the Holodomor, to be an act of genocide.

Harper was also drawn to the Austrian economist Friedrich Hayek's The Road to Serfdom, a post-Depression account of the perils of a state-driven economy. Johnson wrote that this exposed Harper to notion of a "clash of ideologies between communism, fascism, and liberal democracy, which led to world wars and military occupation.” (46) Hayek rejected the planned economy, seeing it as a "threat to freedom" that would put society on a path to "totalitarianism." (47) In 1974, Hayek won the Nobel Prize in economics, and his principles would influence a new generation, including Harper. (49)

Years later, Harper would explain exactly how the perceived evils of communism fit his political ideology. As he wrote in the western Canadian magazine, Citizens Centre Report, Harper said: "The fall of the Berlin Wall signaled the collapse of Soviet Communism as a driving world force, depriving conservatives of all shades of a common external enemy." (2003a) In Harper's view, the conservatives needed the "common enemy" of communism. And losing that had direct domestic policy implications - it meant the conservatives needed a new common enemy. "What this means for conservatives today is that we must rediscover the common cause and orient our coalition to the nature of the post-Cold-War world," Harper wrote. (Ibid) 
After winning power, Harper would wage a spirited political battle to build a large monument to victims of communism on a very prominent patch of land on Ottawa's main ceremonial street. The project continues to be pursued over the vocal objections of the Chief Justice of the Supreme Court of Canada, Ottawa's mayor, local Liberal and New Democrat MPs, the Royal Architectural Institute of Canada and the Ontario Association of Architects, and no less than 17 past presidents of the Canadian Bar Association, all have criticized the ostentatious plan for the massive memorial on a site next to the Supreme Court building.

"Praise will come from the intended political targets of the memorial: individuals and descendants of those who fled communist regimes, especially in Eastern Europe. Poles, Ukrainians, Czechs, Hungarians and people with lineage to the Baltic states are the target groups," wrote Globe and Mail columnist Jeffrey Simpson. "The Conservatives have worked very hard to attract these voters by other means, and the memorial represents a further tangible demonstration of the party's efforts. That the memorial has nothing central to say about Canadian history, per se, but rather of diaspora histories is irrelevant." (Simpson)

As a young man, Harper's fascination with communism was also stoked by Peter Brimelow's The Patriot Game: National Dreams \& Political Realities. That book, wrote Johnson, was "a call to arms" at a "time of disillusionment" for people like Harper. (51) The book was fuel for the anti-Liberal fire that would burn in Harper in the coming years. "For Brimelow, the Liberal Party is the villain of Canadian history. It imposed a way of thinking about the country, a vision, that was detrimental," wrote Johnson. (52) "In effect, the Liberal Party became the surrogate of French Quebec, ruling the country 
because our parliamentary electoral system allowed a minority to rule the majority:

French Canada voted as a bloc, while English Canada was split." (Ibid) Brimelow saw this as leading to the creation of a "New Class" of politicians, civil servants, employees of multiple Crown corporations such as the $\mathrm{CBC}$, welfare workers, teachers, and journalists. (53) It is not too big a stretch to see how Harper would incorporate the international multilateral framework, most notably the United Nations, into Brimelow's view of an elitist, establishment club. Brimelow gave Harper a theoretical foundation for his deep-seated antipathy towards the Liberals, and his eventual desire to crush the party's brand. Brimelow also helped sow Harper's suspicion of the institutions that he saw as supporting the status quo he had come to so vehemently oppose.

Harper viewed the success of Reagan and Thatcher in the 1980s in an ideological light. As he explained in his 2003 article for Citizens Centre Report, he admired their ability to vanquish their domestic political opponents:

The Reagan-Thatcher revolution was so successful that it permanently undermined the traditional social-democratic/left-liberal consensus in a number of democratic countries. It worked domestically to undermine the left-liberal or social-democratic consensus, causing those parties to simply stop fighting and adopt much of the winning conservative agenda. (2003a) Harper is again emphasizing the need to cripple or destroy the Liberals, all part of making the Conservatives the natural governing party of Canada. In the 1980s, Harper was drawn to Thatcher and Reagan because he had grown disillusioned with Mulroney's brand of conservatism. He sought out Thatcher's party manifestos from the 1979 and 1983 elections. Harper embraced Thatcher's rise "and the turn towards free markets," wrote 
Johnson, which made him question what he saw as Mulroney's lack of commitment to those principles. (Ibid) More than a decade later, the example of Australia's John Howard offered more than ideological inspiration: it gave Harper's team some concrete examples of how to appeal to voters. Howard introduced Harper to the importance of political branding. As Tom Flanagan, Harper's former top adviser and occasional co-author, wrote: "People are looking for a sharper definition of what the alternative government stands for.” (209) Flanagan recalled a memo from one of Harper's senior advisers in April 2004 that said: "We must define ourselves in our own ads from the outset before the Liberals define us." (Ibid) That eventually led to the creation of the Conservatives' "Stand Up For Canada" motto. (Ibid)."Around the world, Conservative parties rarely win elections unless they become identified as the party of patriotism; certainly that has been true of the Republicans in the United States and the Conservatives of Great Britain," wrote Flanagan. (Ibid) "But we would have to work to reclaim the ground of Canadian patriotism that the Liberals had managed to appropriate for themselves." (Ibid)

The 2002-03 political debates over Canada's possible participation in the U.S.led coalition to topple Saddam Hussein in Iraq brought Harper's worldview into sharp focus. The debates laid bare Harper's antipathy towards the Liberals and his disdain for multilateralism, as embodied by the United Nations. The Chrétien government, in what was an $11^{\text {th }}$ hour decision just before the first U.S. bombs fell on Baghdad, decided Canada could not join the attack because it was not sanctioned by a new UN Security Council resolution authorizing force. Harper vehemently opposed the Chrétien government's decision on several grounds: he believed existing UN resolutions on Iraq, which were routinely ignored, provided the authority for an attack. "Our position is that 
current United Nations resolutions provide sufficient international justification for action.” (Qtd. in Johnson 321) But even without that, Harper saw Canada's bilateral relations with the U.S. as paramount - it trumped the UN. Moreover, Harper saw it as offensive for Canadian foreign policy interests to be essentially dictated by the UN. In the first Iraq debate in the House of Commons on Oct. 1, 2002, Harper said Canada's response would be "a test of its values, vision, reliability as an ally, and its sense of international responsibility.” (Qtd. in Johnson 319) Harper expressed willingness to work outside the UN if necessary to stop Saddam, distinguishing himself from the Liberals, who generally insisted on working within the UN system to get a new resolution:

Whether or not the Security Council passes a new resolution, a clear and unmistakable message must be sent to Saddam Hussein that his failure to comply completely with not only UN weapons inspection, but also with the removal of any and all weapons of mass destruction and their components, constitutes legitimate ground for direct action to remove the threat of those weapons. (Qtd. in Johnson 320)

Harper attacked the Liberals for their "neutralist" position, criticizing the UN as ineffective and Chrétien for being bound by what he saw as the waffling of the Security Council. "The government undermines Canada's reputation with its allies and does nothing to uphold the credibility of the United Nations by not joining in sending a clear message to Hussein that failure to comply will bring consequences." (Qtd. in Johnson 322) In the second Iraq debate in the Commons on Jan. 29, 2003, Harper again stressed that Canada can't be bound by the will of the United Nations. "Let us talk about the importance of the United Nations. Since the Gulf War in 1991, it has passed some 15 
resolutions. It is important for the UN's credibility to have these resolutions respected. If Saddam Hussein can ignore some 15 resolutions on this matter, what value will the United Nations have in the future?" Harper argued. (Harper "Hansard") "In my opinion, if the United Nations cannot act in the future, it is up to each sovereign nation to take its own decisions.” (Ibid) Fellow MPs Chuck Strahl, Jason Kenney and Stockwell Day echoed the leader's position: If an ineffective UN could not deal with Iraq, Canada must not be bound by it. (Ibid)

Harper's speech in the House of Commons on March 20, 2003, after Chrétien announced Canada was opting out of the U.S.-led coalition, was significant for another key reason - it was quite literally transformed into a tool of partisan political politics. The speech, shot through with denunciation of the Liberals, was reprinted and distributed to party faithful, apparently as a fundraising tool. Flanagan, his former senior advisor, recalled how "thousands of copies" of the speech were printed in pamphlet form and mailed out. "As far as I could judge, there was strong support from the grassroots of the party," Flanagan wrote. (89) This is perhaps one of the strongest examples of Harper's team using international affairs for domestic political gain. In the pamphlet, Harper offered his supporters one more scathing indictment of the Liberals:

We will not be neutral. We will be with our allies and our friends, not militarily but in spirit we will be with them in America and in Britain for a short and successful conflict and for the liberation of the people of Iraq . . . We will not be with our government, for this government, in taking the position it has taken, has betrayed Canada's history and its values. Reading only the polls and indulging in juvenile and insecure anti-Americanism, the 
government has, for the first time in our history, left us outside our British and American allies in their time of need. However, it has done worse. It has left us standing for nothing, no realistic alternative, no point of principle and no vision of the future. It has left us standing with no one..." (Qtd. in Flanagan 88-89)

Harper unleashed one more political rocket at the Liberals over Iraq. He wrote an op-ed article that appeared in the National Post after George W. Bush's infamous "Mission Accomplished" photo-op on a U.S. aircraft carrier in which the U.S. president prematurely declared victory in Iraq in May 2003. Harper wrote that the time had come to "rethink the fundamentals of Canada's foreign policy" because a "series of events since 9/11 has laid bare the failure of the Liberals to uphold Canada's values and interests in the world." (2003c) He derided Canada's past adherence to UN multilateralism and — ignoring the commitments to it by Diefenbaker and Mulroney — squarely labeled it a Liberal phenomenon. (Ibid) Harper accused the Liberals of a "weak nation strategy" that used "multilateral participation to conceal and deny dependency on its key ally." (Ibid) Harper called for unequivocal support for the United States to overcome the "unreliable" rules of the multilateral system. (Ibid) "The time has come to recognize that the United States will continue to exercise unprecedented power in a world where international rules are unreliable and where the security and advancing of the free, democratic order still depends significantly on the possession and use of military might." (Ibid)

In a separate op-ed, this one published a month earlier, Harper had taken his argument to a wider audience — he wrote directly to the American public. Harper cowrote a much shorter but no less forceful op-ed article with his foreign affairs critic 
Stockwell Day, which ran in the Wall Street Journal, under the headline "Canadians Stand With You." (Harper 2003b) They accused Chrétien of making a "serious mistake" by keeping Canada out of the Iraq coalition. Harper and Day brought a domestic partisan disagreement directly to the American public: "Make no mistake, as our allies work to end the reign of Saddam and the brutality and aggression that are the foundations of his regime, Canada's largest opposition party, the Canadian Alliance will not be neutral. In our hearts and minds, we will be with our allies and friends. And Canadians will be overwhelmingly with us," they wrote. (Ibid) "But we will not be with the Canadian government." (Ibid) So much for "water's edge" politics.

In the fullness of time, those grand gestures would bring Harper and his political allies crashing down on the wrong side of history. Saddam Hussein's suspected arsenal of weapons of mass destruction — the rationale for the U.S.-led invasion — was proved by history to have been fiction. Harper eventually admitted he made a mistake. During the 2008 federal election campaign Bloc Quebecois leader Gilles Duceppe pressed him on the issue. Their exchange happened on a televised leaders' debate, five years after the Iraq invasion, and after the hugely unpopular war had claimed the lives of thousands of American soldiers. "It was absolutely an error," Harper said of his earlier support of the Iraq war. "The evaluation of weapons of mass destruction proved not to be correct that's absolutely true." (YouTube 2009) That admission of error did not hurt Harper. Under his leadership, the Conservatives went on win their second minority government in 2008. Iraq had simply ceased to be an issue in Canadian politics. Harper had successfully adjusted his foreign policy outlook, dictated by the heat of domestic political warfare. It would not be the last time he did that. 


\section{Chapter Two: Stormy Relations with the United Nations}

October 10, 2010. More than 60 African and Arab leaders are mingling in the Libyan coastal city of Sirte, the birthplace of their host, Moammar Gadhafi. It's the second such Arab-African summit, and the mood is upbeat without a hint of the violent historic turn of events that will happen here 373 days from now. That's when Gadhafi will take his last breath after being slaughtered by rebel forces, ending his four decades of dictatorial rule and plunging his oil-rich country into anarchy. Ferry de Kerckhove, Canada's ambassador to Egypt is here, working the room and picking up strong hints about something far more imminent and, for his country's place in the world, foreboding — a historic political defeat that Canada will suffer in the next 48 hours.

In two days, Canada will be competing against Germany and Portugal for two temporary seats on the United Nations Security Council in a vote at the General Assembly. Prior to arriving in Egypt in 2008, de Kerckhove spent four years based at Foreign Affairs headquarters in Ottawa as head of its international organizations unit the branch that liaises with UN organizations. De Kerckhove expended much effort on wining and dining Ottawa-based foreign diplomats to curry support for Canada's Security Council bid. Now, out in the field, he has been dispatched along with a number of other government officials — though no cabinet ministers — to Libya for this one-stop shopping summit of one of the UN's most powerful voting blocs: 54 Arab-African members of the UN General Assembly, representing more than one-quarter of the UN's 190-plus nations.

"You have everybody that you needed to buttonhole. The Portuguese, who were fighting for their lives, sent a minister and therefore had greater access to all the leaders," 
de Kerckhove said in an interview. "I remember knocking on the elbow of the King of Saudi Arabia, who didn't think it was very funny, but he sent me to his foreign minister and we had the discussion."

As De Kerckhove continued to work the room, he started to get that sinking feeling. "I'm not going to start naming countries, but there were countries who were pretty clear about saying that our position on the Middle East was not helpful, and that Canada was no longer seen to be the balanced country that had helped in the past," he recalled.

"And that's as simple as that. So there was no question we were going to lose some of the Middle Eastern vote."

And so it was.

Two days later, the UN General Assembly delivered Canada an unprecedented rebuke: it elected Portugal on the second ballot, easily thumping Canada, and denying it another two-year, non-permanent stint for 2011-12. It ended Canada's run of six successful elections to the council since the creation of the UN in 1945. Canada was able to win two-thirds approval of the full General Assembly to serve in 1948-49, 1958-59, 1967-68, 1977-78, 1989-90 and 1999-2000. But in 2010, Canada threw in the towel after its dismal second-round showing: it got just 78 votes to Portugal's 113. (Edwards) Portugal actually needed 128 votes, but rather than face a further humiliation, Canada pulled the plug and conceded. Adding insult to injury was the fact that Canada claimed to have had the written support of $135 \mathrm{UN}$ countries — promises, it would seem, not worth the paper they were printed on. (Ibid) Australia suffered the same fate in 1996, prompting 
its ambassador, Richard Butler, to coin the term "rotten lying bastards" to explain his country's loss. (Malone)

Canada's defeat was widely seen as a repudiation of the Harper government's foreign policy and general antipathy towards the United Nations. There was agreement among scholars and former diplomats that the loss could be pinned on a Conservative government that did a bad job of campaigning for the seat — leaving the push to win far too late in the game - and alienating potential supporters with some of its new foreign policies, including Canada's vocal tilt towards Israel in the Middle East conflict, and its 2010 decision to freeze international aid to Africa. (Stairs, Fowler) These policies would cost Canada many votes among the African and Arab blocs, among others.

Stephen Lewis, the New Democrat who served as Brian Mulroney's ambassador to the UN in the 1980s, says the UN Security Council loss showcases the "ideological dogmatism of Stephen Harper" and has seriously hurt Canada in the eyes of the world. The pro-Israeli stance and numerous examples of indifference on climate change all undermined Canada's chances in the vote. But there was also a general sense "that Canada didn't like the United Nations — which was true, and Canada didn't care about the United Nations - which was true," Lewis told me. At 77, Lewis is still active in the UN, working on sexual violence and peacekeeping operations, which takes him to the offices of the Under Secretary General of Legal Affairs and the Under Secretary General of Peacekeeping. He interacts with a lot of military leaders, a number of them from Africa, and rubs elbows with Kofi Annan, the former secretary general and Nelson Mandela's widow Graca Machel, who was won international awards for her work trying ease the suffering of children in conflict. "When we have finished the business that we're 
dealing with specifically, like peacekeeping, we talk broadly about Canada's reputation and involvement and for everybody — everybody — there has been a significant diminution of Canada's reputation. They often ask me what's gone wrong, what's gone haywire, why is Harper behaving as he is behaving?"

Denis Stairs, professor emeritus of political science at Dalhousie University, blamed an inexperienced team of young aides in the PMO, their eyes firmly fixed on getting the Conservatives reelected in the next election, for simply blowing it at the UN. "Foreign policy is being made largely in the Prime Minister's Office by people who are preoccupied with domestic electoral politics, who are focused on the very short term, who are ignorant of the subtle nuances of international diplomacy and who are inclined to operate from ideological first premises rather than on the basis of a seasoned understanding of what is likely to be constructive and helpful in the international context," he wrote. (Stairs) As a result, the government simply hadn't put in the diplomatic effort required to mount an effective campaign, but was already impaired by its contentious approach to foreign policy making.

De Kerckhove saw the first signs of trouble years earlier during his $2004-2008$ posting to Ottawa, his second to last job post before retiring in 2011. Three times a week, he would host a luncheon at department headquarters in the Pearson Building for groups of Ottawa-based foreign ambassadors, to talk up Canada's candidacy for the Security Council. The problem was, the newly elected Harper government wasn't saying anything publicly about pursuing a seat. Outgoing Liberal prime minister Paul Martin greenlighted the campaign in 2004 as a matter of course — Canada's previous stint had 
finished four years earlier and it was taken for granted the country would go to bat again, roughly a decade later, de Kerckhove recalled.

"I think the Harper government was in its early days, and hadn't looked at the campaign, and had not decided whether they were going to continue to pursue it. And that's perfectly legitimate for a government that comes to power to look around and say, 'Do I really want to continue that?"' he said. "What I'm blaming the government for is having hesitated for quite a while, and once they decided to get in, for not putting in all the effort that was required."

As de Kerckhove's luncheons progressed, he began to notice problems. "The government's position on the Israeli-Palestinian conflict started hurting them considerably. And also the lack of personal investment on the part of the prime minister also made it a more difficult thing to run," he said. De Kerckhove recalled having some "wonderful discussions" with his friend the Brazilian ambassador, who spoke fluent French. "I knew perfectly well that the luncheon was a bit of a waste of your tax dollars because I knew perfectly well he was going to be supporting Portugal and Germany, and not us." De Kerckhove said he wasn't aware of any high-level political phone calls from the prime minister or foreign affairs minister to potential supporters - in those early days. He also said the government could have demonstrated "a bit less harshness on some positions to allow a bit of space so countries could vote for you."

Harper had heaped a heavy dose of criticism at the UN when he first took to the General Assembly podium on Canada's behalf in 2006. Harper bluntly stated that the UN needed to do a more responsible job spending its money — the money of its donor countries. The UN had faced no shortage of criticism after too many corruption and 
mismanagement scandals in the previous decade, particularly the oil-for-food scandal that undermined sanctions on Iraq. In what was the widely viewed as the biggest threat to the UN system, more than 2,200 reputable firms made more than $\$ 1.8$ billion in payments to Saddam Hussein's regime, a scam that exploited a program to designed mitigate some of the effects of the sanctions on innocent Iraqi civilians. (Economist) But Harper, the new kid on the block, was telling the institution to its face that it needed to shape up. "Earlier this year, Canada's New Government was given a mandate to make our national government more accountable, to ensure taxpayers get full value for their money, and to pursue a clear, focused agenda that produces tangible results," he told the assembly. (Harper 2006b)

"The United Nations should accept nothing less. This organization must become more accountable and more effective. Management reform must continue, and at an accelerated pace. The taxpayers of member nations, Canadians among them, make significant financial contributions to this organization," he said. "They have the right to expect stronger, more independent oversight mechanisms, more robust accountability for how funds are spent, and human resources practices that are based on merit." (Ibid)

On Sept. 23, 2010, Harper addressed the General Assembly for the second time in four years, this time in an attempt to win support for Canada in the Security Council vote that was just 19 days away. Harper's speech didn't help matters, said Stairs, because "he made a public, crudely transparent, and unprecedentedly self-serving pitch in support of the Canadian cause." (Stairs) In Harper's case, his return to the assembly came one year after his infamous snub, when he decided to take part in a photo-op at a Tim Hortons donut factory in Oakville, Ontario instead of speaking at the UN. On paper, Harper had a 
strong argument to make that Canada was a strong and worthy candidate: not only was it the UN's seventh largest funder, it was contributing to global security through the sacrifice and heavy casualties suffered by the Canadian Forces in the UN-sanctioned war in Afghanistan. Harper reminded the assembly of Canada's role in the founding of the UN in 1945, and described his government's recent commitment to improving the plight of pregnant women, young mothers and their newborns in the developing world — his signature foreign aid initiative — and how that dovetailed with the UN's Millennium Development Goals. Most of all, he talked about the ongoing war in Afghanistan, and the sacrifices of the Canadian Forces, as casualties continued to mount. (Harper 2010b)

“Canada continues to pay, for instance, a heavy price to fulfill our UN obligation to support the lawful government of Afghanistan," the prime minister said. "We pay it in both the resources of Canadian taxpayers, but also with profound sorrow in the priceless lives of our young men and women who serve there in the Canadian Armed Forces, as well as, sadly, civilians who have also given their sweat and their lives in the service of both our country, and of the people of Afghanistan." (Ibid) Without mentioning it specifically, Harper was evoking Article 23 in the UN Charter, which placed a premium on a country's contribution to peace and security when vying for a temporary Security Council seat. Harper kept the anti-UN rhetoric out of this speech, saying Canada remained committed to the founding principles of the UN, "through peace and development, to build a better world. To prevent war and conflict, yet at the same time, to uphold what is right and to protect the weak and the poor from those who prey upon them." (Ibid) 
The argument failed. Stephen Lewis says the loss falls squarely at Harper's feet for his "negative, contemptuous dismissal of the United Nations as a useful forum." When the General Assembly reconvened in September 2011 with the Conservatives fully entrenched in a majority government, Harper unleashed his new pit bull of a foreign affairs minister on the UN.

John Baird arrived at the General Assembly guns blazing and teeth bared, ready to relay to the international community the same message that Harper gave to Conservative supporters in Ottawa earlier that summer. Baird declared that Canada was done with going along "to get along" at the UN. (Baird 2011) Baird flaunted Canada's support of Israel in what had all the hallmarks of a slap back at the bloc of Arab and Muslim countries that many believed had cost Canada the election to the Security Council. He equated Israel's modern day critics — and there are many at the UN — with the appeasers of Nazi Germany in the lead up to the Second World War. (Ibid) "Just as fascism and communism were the great struggles of previous generations, terrorism is the great struggle of ours. And far too often, the Jewish state is on the front line of our struggle and its people the victims of terror," the new foreign minister said. (Ibid) "Canada will not accept or stay silent while the Jewish state is attacked for defending its territory and its citizens. The Second World War taught us all the tragic price of 'going along' just to 'get along.'” (Ibid)

Just as Harper had done in 2006 — but chose to overlook in 2010 when he was campaigning for the Security Council seat — Baird blasted the UN itself for allowing countries with dubious rights records to be members of the Human Rights Council where they could sit in judgment of more upstanding countries. "The greatest enemies of the 
United Nations are not those who publicly repudiate its actions," he said. (Ibid) "The greatest enemies of the United Nations are those who quietly undermine its principles and, even worse, by those who sit idly, watching its slow decline." (Ibid)

Canada's new, more robust foreign policy sparked a heated and polarized domestic debate that pitted seasoned diplomats and academics against each other. Detractors — and there are many — as well as supporters of the Harper government agreed on one thing: the conduct of Canada's foreign policy, particularly its multilateral engagement with the UN, has been fundamentally altered since 2006. Robert Fowler is Canada's longest serving ambassador to the UN and a public servant with impeccable bipartisan credentials: he was a foreign policy adviser to both Pierre Trudeau and Brian Mulroney. In a 2013 opinion column, he characterized the Conservative government's “"we won't go along to get along' mantra" as smug and simplistic. (Fowler) He said the underlying attitude cost Canada its 2010 Security Council bid, and he predicted that unless there was a fundamental change in foreign policy, Canada would remain on the sidelines. (Ibid) The McLeod Group, a collection of Canadian foreign policy experts that includes senior former public servants and diplomats, researchers and civil society advocates, said Canada had become a "third-rate verbal bully" under the Conservatives, which was working against the country's national interest in promoting a safe world. (McLeod Group 2012) “Talking peace has never meant 'going along with tyrants and dictators' as the Prime Minister so bluntly puts it," said a statement posted by the group. It said Harper's foreign policy choices, especially between 2006 and 2011 when he had minority governments, were all about winning a majority, and that foreign policy was "a useful domestic tool" in this pursuit. "His 'gunslinger' style plays well with his core 
supporters - Westerners, especially Albertans, the Christian right and other social conservatives - and he has catered to them," the group wrote. (Ibid) "It has also allowed him to reach out to new constituencies such as diaspora communities that may share socially conservative views. Foreign policy has become a useful domestic tool." (Ibid) Former prime minister Brian Mulroney heaped scorn on Harper in September 2014 when he appeared on CTV to mark the $30^{\text {th }}$ anniversary of his first election victory in 1984. Mulroney said Harper had essentially undone decades of good Canadian work at the United Nations. "When Canada, for the first time in our history, loses a vote at the United Nations to become a member of the Security Council ... to Portugal, which was on the verge of bankruptcy at the time, you should look in the mirror and say: 'Houston, I think we have a problem'." (The Canadian Press 2014) Mulroney said Harper's foreign affairs policy "has to be enveloped in a broader and more generous sweep that takes in Canadian traditions and Canadian history in a much more viable way.” (Ibid) He said Canada had to start acting like it was in the "big leagues" and to stop being "out-riders" on the international stage. (Ibid)

One of Mulroney's former U.S. ambassadors and top advisers was far more impressed with Harper's tougher attitude towards the UN. Derek Burney, Mulroney's former chief of staff and an envoy to the United States, was also the head of Harper's transition team when he was taking over the reins of government in early 2006. Burney and his writing partner, Fen Hampson, one of Canada's leading international affairs analysts, said it was about time Canada started addressing the problems with the UN head on, the way Harper was now doing. "The UN is hobbled by an out-of-date structure, ineffective governance and misplaced values and ideals," Burney and Hampson argued, 
and they lamented the "second-rate efforts" of the UN member countries to fix it. (Burney \& Hampson 2012) They defended Harper's various snubs of the UN General Assembly — most notably his decision to attend the donut shop photo-op instead of giving Canada's address to the General Assembly in 2009, as well as skipping the assembly again in 2012 in favour of accepting an award from the Appeal of Conscience Foundation at a New York hotel just a few blocks from the UN. Burney and Hampson insisted that the "the government has good reason to be frustrated with the UN." (Ibid) They said the professors and former Canadian diplomats who were "in a lather" over this "should be directing their wrath at the UN, not the prime minister." (Burney \& Hampson 2013) They called the 2010 Security Council loss "a stinging rebuke to a country that has long done yeoman's service in defence of freedom and the maintenance of international peace and security." (Burney \& Hampson 2012) They argued that the Responsibility to Protect doctrine, championed by the Liberals under Paul Martin, adopted by the UN in 2005, and since jettisoned by the Harper Conservatives, had become "laughable" because of the UN's inability to halt the bloodshed in Syria. (Ibid)

"Syria's civil war is a clear indictment of the world's multilateral security architecture, and a clarion call for Canada to lead efforts to reform a system that has strayed from the principles of humanitarian intervention," Burney and Hampson write in their recent book, Brave New Canada. (73) They described the ineffectiveness of UN sanctions, saying that, "barely 20 per cent of UN sanctions have had any impact at all and only 10 per cent have actually changed the behavior of their intended targets." (Burney \& Hampson 2013) 
Moreover, Burney and Hampson offered a sharp rebuttal to critics who accused the Harper government of not supporting the UN: "In spite of all the criticism directed at the Conservatives, Canada continues to be the seventh largest contributor to the UN's budget," with a bigger contribution than Russia and China, who are permanent Security Council members. (Ibid) They concluded that although "multilateral institutions have long been a key instrument of Canadian foreign policy and a critical vehicle for advancing Canada's interests in the world, the realpolitik is that the UN is "increasingly dysfunctional" and failing to improve global security. (Burney \& Hampson 2014) Canada, they argued, needs to push for UN Security Council reform, and should advocate for Japan, Germany, India, and Brazil to become permanent members. And if there were no progress, Canada should start cutting back its financial support by as much as 10 to 20 per cent a year. "Such a move would send a strong signal that we are serious about UN reform and, since we are the seventh-largest contributor to the UN regular budget, others would take note and perhaps even follow our lead." (80)

For all their tough talk on the UN, Burney and Hampson do not advocate that Canada should turn their back on the institution. "Make no mistake. The world and Canada need viable and effective multilateral institutions," they argued. (82) But Canada can't keep on "drifting" the UN, and needs to push for reform because it is urgent. (Ibid) They clearly advocate Canada playing an active role within the institution to make it better. That argument, at its core, represents a fundamental rejection of the not-goingalong-to-get-along stance that the Harper government loudly advocates.

Harper found a more palatable foreign policy influence in Roy Rempel, who would become a policy advisor in Harper's office in 2010. Since 1998, Rempel had been 
a policy advisor and researcher in the Canadian Alliance and the Conservative Party of Canada. Rempel offered his future boss a theoretical framework in 2007 to back his wholesale rejection of all things liberal — or Liberal — in Canadian foreign policy. He wrote a book called Dreamland: How Canada's Pretend Foreign Policy Has Undermined Sovereignty that argued the Liberals and the Progressive Conservatives simply got it wrong by embracing the UN. Rempel wrote that, "the centre of gravity of any state's international policy should be wherever the livelihood and well-being of ordinary citizens are most affected by international events.” (2) Quoting Canadian political scientist William Hogg, Rempel criticized the Canadian "functionalist" fixation in foreign policy, "meaning the integration of Canada in multilateral frameworks at every possible opportunity — a fixation he described as almost 'pathological."' (71) He argued that the UN could not be at the centre of Canadian foreign policy because it had proven ineffective at preventing genocide in Rwanda and the Balkans, and had given a forum to dictators such as Robert Mugabe and Vladimir Putin. (73) This criticism of Putin would come years before the current Ukraine crisis, but it clearly foreshadowed the hardline rhetoric that Harper and Baird would direct at Putin after Russia's annexation of Crimea and the unrest caused by Russian-backed militias in eastern Ukraine. Rempel was unequivocal about where the UN fits in terms of Canadian foreign policy: "Where the UN is incapable of supporting Canadian interests, it should not be permitted to exercise a veto over the conduct of Canadian international policy.” (78) Along with Burney and Hampson, Rempel offered the Harper government some of the most serious ideological support for its criticism of the UN. 
From the moment he won power, Harper began challenging the traditional assumptions that lay at the heart of Canada's foreign policy. As far as his first nonpolitical foreign policy adviser was concerned, that wasn't necessarily a bad thing. David Mulroney was a seasoned foreign service officer who would rise higher in the ranks under Harper, eventually becoming the deputy minister in charge of the Afghanistan Task Force during the height of the war, and in 2009, the ambassador to China at a key moment when relations between Beijing and Ottawa were at a particularly low ebb. Harper was determined to challenge a way of thinking about foreign policy that "had grown very cozy with identifying Canada's interests with the interests with the multilateral system at the UN," Mulroney, who retired in 2012, told me. "He felt we were too ready to take positions at the UN that didn't reflect what he'd see as the true direction or necessary direction of Canadian foreign policy." The prime example was what Harper saw as the repeated criticism of Israel at the UN while other countries - totalitarian regimes that didn't respect the rule of law or in some cases, their own civilians avoided censure. Without a doubt, this was a hard pill to swallow at the Foreign Affairs Department where the "high priests" of multilateralism looked down their nose at those who promoted bilateral, country-to-country relations, said Mulroney.

"In the past, Conservatives had been as invested in the multilateral consensus. Brian Mulroney's government was like the old Republicans in the U.S. internationalist, links to business, a very strong vision of Canada in the world. And it took the bureaucracy a long time to figure out after 2006 that this is an entirely new government," said David Mulroney. "In many ways, that government had been on the outside, resenting the elites in both the Liberal and Conservative parties." Harper wanted 
his diplomats to stay on message, so he imposed what ultimately became a stifling control of seasoned diplomats. He wanted to avoid precisely the sort of thing that happened in June 2011, when his ambassador to the United Nations in Geneva, Marius Grinius, warmly welcomed the North Korean ambassador into his new appointment as the rotating chair of the UN's Conference on Disarmament. It was the standard welcome that accompanies such a passing of the torch on UN committees. The problem was, Foreign Affairs Minister John Baird had denounced the appointment just a week earlier as unacceptable because North Korea was an international pariah whose nuclear weapons status was opposed by the world and posed a danger to world peace. (Toronto Sun) In an editorial, the Toronto Sun told Baird to fire Grinius, calling him an "absolute twit." (Ibid) To Harper it was "the ultimate icing on the cake," said Mulroney, but the prime minister overreacted by putting all of his senior diplomats on a tight communications leash.

"He didn't trust the department to run that anymore. So everything had to go back. It was micromanaged at the political level," he said. "The diagnosis wasn’t entirely wrong, but the prescription was way too strong."

All of the political micromanagement of the foreign service from Ottawa had stifled the creativity and morale of its members. It extended as far as seeking permission from home in the middle of delicate negotiations abroad, he said.

"It got to the point that even being identified as having been in a meeting would have got you in trouble," Mulroney recalled. "You couldn't be caught in the wrong room, or saying the wrong things: the level of scrutiny was so high it depressed the kind of creative impulses of people on the ground," he added. "You have a kind of command and control diplomacy where people check in: Can I do that? I want to go to this meeting. 
Can I go to that meeting? Can I give this speech?" Now, he said, Canada has a new generation of diplomats that shies away from doing anything creative, filled with "people who are really scared they'll get in trouble if they say just about anything."

The overriding imperative at the heart of the Harper government's new direction in foreign policy is to perpetuate the rule of the Conservative Party of Canada. Before 2006, this was about winning power from the Liberals, which Harper viewed as the natural governing party of Canada. Since then, it has been about consolidating power by smashing the Liberal brand, and redefining Canada. As Harper himself said in 2008: My long-term goal is to make Conservatives the natural governing party of the country. And I'm a realist. You do that two ways ... One thing you do is you pull conservatives, to pull the party, to the centre of the political spectrum. But what you also have to do, if you're really serious about making transformations, is you have to pull the centre of the political spectrum towards conservatism. (Qtd. in Nossal 2013, p. 22)

Harper himself made no secret of his desire to break with the past - the Liberal past and reconfigure Canada's position on the world stage. In his first major foreign policy speech after he won power in 2006, the prime minister told an audience at the Wilson Centre in Washington, D.C. that he planned for Canada to play a more influential role on the world stage — but not necessarily in multilateral organizations, such as NATO, the G8, the Francophone and the Commonwealth: "To accomplish such a goal will require more than membership in the various multilateral bodies I have just talked about." (Harper 2006c) For Harper, this meant breaking with the way things had been done in the 
past, primarily under the Liberals: "Previous governments have had all those club memberships, but they haven't always been leaders." (Ibid)

Harper came to power in 2006 with little international experience, but he had clearly developed strong doubts about the UN's effectiveness. Harper arrived in office facing "a severe shortage of experience on the front bench," wrote Canadian diplomat Louise Frechette, who served as the first UN deputy secretary general between 1997 and 2005. (Frechette 269) To compensate, the Conservatives fell back on ideology. "The new government's foreign policy priorities — few in number and sketchily defined — seemed to respond both to genuine ideological differences with the Liberal party and an intense desire to appear to be different." (Ibid) Frechette said she noticed the influence of domestic political considerations gaining importance in Canadian foreign affairs near the end of Liberal era, as her term at the UN was winding down. In 2004, the country embarked on a period of "prolonged political uncertainty" with seven years of minority government, she said. (Ibid) Kim Richard Nossal, director of the School of Policy Studies at Queen's University, said Harper's foreign policy was driven by, "the primacy of the ballot box. In this view, what we have seen is international policy shaped first and foremost by electoral considerations, and in particular the broader strategic goals of the Harper Conservatives to become Canada's 'natural governing party'.” (Nossal 2014) Roland Paris, the founding director of the University of Ottawa's Centre for International Policy Studies, wrote that "Harper and his colleagues seem to regard the principles of liberal internationalism as more Liberal than liberal — that is, as a hallmark of the Liberal Party of Canada - even though they provided a largely non-partisan basis for foreign policy over the preceding 60 years." (Paris 2014) The Conservative foreign 
policy derides soft power diplomacy, equates debate with dithering, and views these shortcomings as an extension of failed Liberal policies of the past, wrote Paris. "This shift has been especially evident in Canada's behavior toward multilateral institutions, including the UN, which is still the centrepiece of the global multilateral system," he added. "Promoting a new approach to international policy was apparently not enough; the old approach also had to be delegitimized — as weak, mealy-mouthed, unprincipled, pusillanimous, and mired in moral failure." (Ibid)

After serving under Harper in a number of capacities, David Mulroney, now a senior fellow at the University of Toronto's Munk School of Global Affairs, came to the conclusion that the Harper Conservatives really didn't care what the UN thought of them. "I don't think he was interested in the multilateral relationship at all. I don't think they really cared that they did damage to it," he said. "The fact that they would go and say those things and rattle the furniture as much as they did suggested they weren't overwhelmed by the institutions." Harper behaved that way to appeal to a core constituency inside Canada, one that helped bring his party to power. "The people that they wanted to reach reflect those positions. And that again gets to this notion of domestic politics," said Mulroney. "You don't want to be hypocritical and ignore what people believe domestically, but sometimes you have to say, the world is a complicated place, we have to compromise sometimes."

There's nothing necessarily new, or wrong, with any government assessing how foreign policy choices will affect its domestic political fortunes. But as ex-diplomat Ferry de Kerckhove saw it: "The problem with the Harper government is that in electoral politics its own perspective dominates as opposed to the interest of the global commons." 
The most glaring example of how Harper has thumbed his nose at the United Nations is how he has undermined the UN treaty system. "If you look at the listing of treaties that were not ratified, signed or otherwise, you will always find a direct link to the ideological proclivities of the present government."

The current Conservative government has demonstrated a particular disdain for an important UN function: the crafting of international treaties. Canada has not signed the UN Arms Trade Treaty (ATT) to regulate the global trade in conventional arms — from guns to tanks. It has also become the only country in the world to withdraw from the UN Convention to Combat Desertification in 2013. (Blanchfield "desert convention") On the ATT, the government has faced pressure from recreational firearms users in Canada, who believe the UN treaty would somehow meddle with their lawful rights to possess weapons. The evidence is clear that the government's decision not to join the ATT is based on a domestic political calculation: it does not want to be offending a core group of supporters, rural gun owns and sport shooting enthusiasts. Harper's longest serving foreign affairs minister John Baird has explicitly stated the ATT could lead to a revival of the now abolished federal long gun registry. (Blanchfield "Firearms lobby") The Conservatives promised in 2006 to do away with the registry, which was hated by rural gun owners, a core domestic constituency for the party. It was finally able to make good on the promise in February 2012 after securing a majority government. (Ibid)

Two of the top players in Canada's gun lobby told me that it was in the Conservatives' domestic political interest to stay away from the ATT. Tony Bernardo, head of the Canadian Shooting Sports Association, said he had been working hard to 
oppose UN gun control efforts since the mid-1990s, and that he had found a great ally in Baird. "Minister Baird has been very thoughtful and intelligent on the Arms Trade Treaty right from Day One," Bernardo said in an interview. (Ibid) "At the beginning of the process he asked the United Nations to remove civilian firearms from the scope of the treaty. He's seen the writing on the wall. He's not a dumb man." (Ibid) Sheldon Clare, president of the National Firearms Association, said: "I think they also recognize there would be some significant ramifications in their voting base were they to approve this." (Ibid) Clare said he was worried that the ATT would lead to higher prices on the imports of firearms, ammunition and accessories. (Ibid) "We rely heavily on imports." (Ibid) Industry Canada data shows that the imports of guns, rifles, shotguns, ammunition and accessories nearly doubled during the first seven years of Conservative rule. From 2006 to 2012, they totaled \$2.84 million. During the final seven years of Liberal rule, between 1999 and 2005, weapons imports to Canada totaled \$1.56 million. (Ibid)

Meanwhile, Baird's office door remained open to the gun lobby. According to a heavily censored briefing note released under Access to Information, Baird agreed to Clare's request for a meeting on May 9, 2012 in his Centre Block office. (DFAIT 2012a) One of Baird's key messages was that Foreign Affairs "will continue to find efficient ways to facilitate the lawful importation of firearms and their accessories." (Ibid)

With the August 27 to September 7 conference at the UN on small arms and light weapons looming, Associate Deputy Minister of Foreign Affairs Gerald Cossette prepared a briefing note for Baird that proposed "Canada play a low-key, minimal role at the Review Conference (RevCon)." (DFAIT 2012b) Cossette wrote in the July 11, 2012 memo, released under Access to Information, that the conference was taking place three 
weeks after the ATT negotiations were set to wrap, and there were "similar issues at play." (Ibid) Canada's position should be to ensure, "(1) no new burdens are imposed on law-abiding, responsible Canadian firearms owners; and (2) that Canada does not enter into any new commitments that are inconsistent with its domestic laws and regulations on firearms." (Ibid) The senior bureaucrat made it clear this was controversial. "The Canadian delegation is likely to face criticism or questioning by some delegates on this approach . . . and Canada could be isolated from traditional friends and allies," Cossette wrote. (Ibid) "Critics may view any attempt by Canada to seek voluntary language in an outcome document as further evidence that Canada is attempting to undermine all forms of gun control, including at the international level." (Ibid) Cossette also suggested that the Conservatives might be able to avoid controversy because the conference was essentially taking place during the dog days of summer. "As the RevCon will be taking place during the summer recess, it is unlikely to generate a lot of interest among Parliamentarians." (Ibid) The "proposed Canadian delegation" to the UN was to include four people: three officials from Foreign Affairs, and Steve Torino, president of the Canadian Shooting Sports Association. (Ibid) In a clearly legible handwritten script at the top of the memo, it read: "Approved by the Minister on August 23, 2012. JB." (Ibid)

The Harper government's decision to withdraw from the Convention to Combat Desertification shocked the German-based secretariat that administers it, and represented a blatant snub of the UN treaty system. Canada ratified the convention in 1995, which created a UN body that researches ways to stop the spread of droughts that destroy farmland across the globe, especially in Africa. The federal government posted a cabinet order online that "authorizes the Minister of Foreign Affairs to take the actions necessary 
to withdraw, on behalf of Canada, from the United Nations Convention to Combat Desertification, in those Countries Experiencing Severe Drought and/or Desertification, particularly in Africa." (Blanchfield "Canada quits") The government forgot one other important thing: it didn't bother telling the UN any of this. The UN secretariat did not initially find out from the Canadian government that Canada was, in fact, withdrawing. I'm the one who told them. On March 27, 2013, after I phoned the UN secretariat in Bonn, the spokeswoman there told me: "We cannot comment on something that is not communicated officially to the secretariat or to the United Nations." (Ibid) The woman said she was going to be calling the secretariat's lawyers. (Ibid)

The next day, Morris Rosenberg, Canada's deputy minister of foreign affairs, sent Baird a one-page briefing note recommending, "that you sign the attached letter to the UN Secretary-General informing him of Canada's withdrawal from the UNNCD." (DFAIT 2013) An X was penned through the "I concur" box, and the top of the page was marked with the same clearly legible handwritten script as the earlier Arms Trade Treaty signoff: "Approved by the Minister on March 28, 2013. JB." (Ibid) With that stroke of the pen, the convention now boasted 193 member countries, including the European Union - the rest of the entire UN, minus Canada. Suddenly, Canada became the only country in the world to be outside a 20 -year-old convention designed to combat the global threat of increased droughts and lost farmland. The UN called that "regrettable." (Blanchfield "pullout regrettable") Baird defended the desertification pullout saying, it was a waste of taxpayers' money — Canada contributed $\$ 350,000$ annually to the convention — to support what was essentially a "talkfest." (Blanchfield "pulling out") The convention was admittedly obscure, but following the government's earlier decision 
to withdraw from the Kyoto Protocol climate change treaty in 2011, the move raised eyebrows.

Canada's allies noticed this shift in relation to UN treaty bodies, but few diplomats will speak on the record about this. France is one exception. The former French ambassador to Canada Philippe Zeller questioned the desertification treaty pullout directly. "When it's such a question as to how to deal with desertification — well it's difficult to accept, to see a leader like Canada, countries that are known for having developed aid policy since the 1960s, to decide to go out. But we have to respect that," Zeller said in an interview at the French embassy, a week prior to his departure from Canada in early 2015. (Blanchfield "France's ambassador") Zeller also questioned Canada's decision not to join the Arms Trade Treaty or the long-delayed ratification of the Convention on Cluster Munitions. He suggested his government had been quietly urging Canada to take action on these fronts. (Ibid)

Former Australian prime minister and foreign minister Kevin Rudd supports Canada's tough stand on the UN. Rudd even had a label for Baird: "He is a practical internationalist." Rudd coined the term when I spoke with him during his visit to Ottawa in January 2015 to speak to the Foreign Affairs Department about his new job as the head of the Independent Commission on Multilateralism. Baird and Norwegian foreign minister Borge Brende had been named co-chairs of the commission in September 2014, an initiative launched by the International Peace Institute, a non-profit New York thinktank. It has two years to make recommendations to help UN organizations work more efficiently on dealing global security issues. 
Rudd's mandate encompassed everything from the Security Council to the World Health Organization, but during his interview he said that he was realistic enough to realize he would be able to make only incremental progress during his mandate. Regardless, Rudd said he was happy to have Baird at his side to give the UN tree a little shaking. "I don't think he's the sort of guy who wants to go to conferences for the sake of going to conferences. There are some folks around the world who kind of do that," said Rudd. "He speaks with a high degree of credibility from a realist perspective; he wants to see the UN function and function effectively." Three days after that conversation, in February 2015, Baird announced he was quitting politics.

Rudd was equally impressed with the deep institutional knowledge of the Canadian bureaucracy with regards to the inner workings of the UN. He called Canada's diplomats, "a senior band of officials who know the UN system backwards." Senior managers, foreign service officers and other department officials spent several hours listening to a presentation by Rudd on the future of the UN. He said they were well positioned to reform the UN.

"The particular expertise that could bring about credible reform lies with so many of the folks who have literally decades of experience," Rudd said. "I think Canada is one of the great repositories of — let's call it multilateral knowledge — in the world."

All of that begged the question of whether Canada should be licking its wounds as Australia had done, and mount another campaign to serve on the UN Security Council run sometime soon. After all, Australia had just finished its two-year stint on the council in December 2014, after suffering its own bitter failure to win a seat in 1996. Rudd 
himself launched and led Australia's campaign for the seat in 2008, calling the three and half year battle "tough and taxing," but worth it in the end.

"It's a bit like global Tammany Hall," he said, laughing, "not to be undertaken lightly." Australia, along with tiny Luxembourg, was able to push the yardsticks forward slightly on the Syria crisis with a pair of resolutions that made "modest improvements" to the level of access that humanitarian groups were able to secure to help bring relief to war-torn areas of the country.

Rudd insisted he didn't want to give advice on what Canada should do, but quickly added: "Apart from the question of UNSC membership and candidatures, all I'd say is Canada is a strong, credible voice in the world historically, and is into the business of global problem solving. And we need more and more countries like that."

Zeller, the French ambassador, had been far more categorical when I him asked the same question a few days earlier. Zeller was one week away from leaving Canada after three and a half years in Ottawa, and appeared more at ease to speak his mind during a lengthy chat in a high ceilinged French embassy sitting room overlooking the frozen confluence of the Gatineau, Rideau and Ottawa rivers. "I think it's important to have partners (such) as Canada being a member of the Security Council," Zeller said, adding that Canada had a role to play as a bridge between other countries, particularly in Asia and Latin America. (Blanchfield "France's ambassador")

$$
* * *
$$

Stepping back briefly into Canada's early UN history, one can understand a little more clearly how Canada tried to be a bridge builder during its initial stints on the Security Council. Canada's debut in 1948 was filled with equal amounts of drama and 
trepidation. But the view that the country could be a bridge builder — between the five permanent powers, and between those countries and the rest of world — was immediately recognized as a role Canada was well suited to play. There was debate within the St. Laurent government over whether Canada should try for a council seat. At the External Affairs Department, senior mandarin Hume Wrong wondered whether it would be too much of a burden on the department, and at the High Commission in London, diplomat John Holmes said that although it would be a "crushing load" on the department, it would be good for morale. (Hilliker and Barry 32) Lester Pearson was also torn, as he acknowledged the workload, but he also saw that if Canada took a pass, it might be seen a repudiation of the UN as a whole. (Ibid) In the end, Pearson recommended to St.

Laurent that Canada should run. Cabinet approved the bid in August 1947, and Canada got elected in September for the 1948-49 term. (Ibid) The remarkably short one-month turn around would stand in stark counterpoint to the years'-long, expensive campaigns of the late 1980s and 1990s, including the five-year, \$1.9-million effort that culminated with Canada's sixth and final term in 1999-2000. (Malone)

On Jan. 6, 1948, Under-Secretary of State Lester Pearson took the seat for Canada's first appearance on the council, saying it was a great honour for Canada, and one he hoped the country could live up to. (Smith 1948) One month later, Canada's new ambassador to the UN, the retired Gen. Andrew McNaughton, was chairing the Security Council for Canada's first-ever month-long stint in that leadership role. McNaughton, a former Second World War army commander, took the initiative to help resolve the Kashmir dispute between India and Pakistan that culminated with a deal on Jan. 1, 1949. (Spencer 120) On Dec. 27, 1949 — more than seven months after McNaughton proposed 
a peace conference between two factions that had been locked in four years of fighting in South Asia - the Netherlands signed a sovereignty agreement with the Indonesian Republic, giving birth to what is now the world's most populous Muslim country. (Spencer 122)

"He loved the experience of being in the formative stages of an organization that was essentially set up with the cry of 'never again'," McNaughton's grandson, Andrew Leslie, who would become Canada's army commander for the fiercest fighting of the Afghanistan campaign between 2006 and 2010, recalled in an interview.

Leslie was only nine when his grandfather died, but his own parents have since enlightened him as to how McNaughton and his Canadian contemporaries felt about what they were involved with back then. "I'm told that they saw this as a calling, they saw it as an opportunity to try and help, using instruments other than the nuclear weapon," said Leslie. (Ibid) They realized that the UN was created "to prevent the real protagonists from going at it and killing the rest of us." (Ibid)

Historian Norman Smith recalled McNaughton chairing one particularly raucous session on Kashmir in February 1948. Smith watched from the public gallery when India's Sheikh Abdullah "hurled his defiant threat that no force on earth save his own people could take him from power in Kashmir," and just as two women from Brooklyn were settling into seats near him. (Smith 1948) "Look," one of them said, "a Canadian is chairman.” (Ibid) Her friend replied: “Good for Canada, I didn't even know they were here." (Ibid)

Sixty-six years later, Stephen Harper arrived in New York to address the UN for the first time in four years, following his failed effort in September 2010 to persuade the 
General Assembly to grant Canada a seventh Security Council term for Canada. A UN staffer, who was overheard by Canadian reporters, said: "So nice of him to show up." (Panetta "big announcement")

Harper's last UN visit in 2014 also contrasted with the hero's welcome his Progressive Conservative predecessor Brian Mulroney received in September 1988, when he made one final push for what would be Canada's fifth Security Council stint. Yves Fortier had only been in New York a few weeks, after his good friend, Mulroney, appointed him to be Canada's ambassador, succeeding former New Democrat Stephen Lewis. "He made it very clear that number one on my agenda was going to be lobbying . .. the other ambassadors in New York to secure their support for Canada's election,” Fortier told me recently. For Mulroney, partisan politics were not part of the equation once he was in the international arena, he said.

"He was a disciple of Lester Pearson," Fortier recalled. "The political colour of these two men, again from Mulroney's perspective, mattered not. What mattered was the fact that Pearson had been an exemplary representative of Canada at the UN."

Canada's campaigning had been going on for years, and even though he was parachuted in for the final weeks, Fortier was determined to make the most of it. When a new ambassador presents his credentials at the UN, he pays courtesy calls to his fellow senior diplomats, so Fortier turned those visits into campaign stops. "I combined my courtesy visit with a plea for their support, that country's support. I was encouraged by the reaction by the majority of my new colleagues," he recalled.

Fortier was also encouraged by a private visit with then-UN Secretary General Perez de Cuellar, who would invite new ambassadors back to his office for a private tete- 
a-tete and a "coup de champagne." De Cuellar told Fortier: "When I want to give an example of how a country should behave if it is a member of the United Nations, I always refer to Canada." As he walked back to the Canadian mission afterwards, Fortier thought, "he probably says that to every UN ambassador."

Fortier realized de Cuellar just wasn't blowing smoke when, several weeks later, on Oct. 26, 1988, Canada scored a resounding first ballot victory in the General Assembly, garnering 127 of 158 votes to win a seat. Looking back, Fortier said support from African countries played a key role because of Mulroney's leadership on fighting the battle against apartheid in South Africa. "No question, no question. The African countries were very grateful to Prime Minister Mulroney for the leading role that he played in ridding South Africa of apartheid."

The Pearson era of foreign affairs from the mid-1940s to the late 1950s is routinely referred to as Canada's "Golden Age" of diplomacy. But when Fortier thinks back on the 1989-90 term at the UN, "those were the golden years of the United Nations. It was at that time that the UN Security Council truly functioned as it was envisaged in 1945.” The Berlin Wall fell. The Soviet Union collapsed. Nelson Mandela walked free after 27 years in a South African prison. The eight-year Iran-Iraq War ended, and the world's geopolitical chess pieces were reconfiguring themselves for Saddam Hussein's quickly thwarted invasion of Kuwait in 1990. And Canada had a front line political seat for it all. Fortier recalled the day the Soviet Union became the Russian Federation literally overnight.

"I remember confidential deliberations between members of the Security Council behind closed doors before you go in for the staged performance in open court, so to 
speak," the veteran lawyer and international arbitrator said. "I remember one day during one of the those informal but confidential sessions - I don't speak Russian so I was being fed the intervention of my colleague, who would become overnight the Russia ambassador - and I thought I was being fed a speech by the American ambassador. I thought I had the wrong translation, the wrong channel.

"It was that revolutionary a change."

On Dec. 19, 2000, Paul Heinbecker, then Canada's ambassador the UN, offered the last utterance by Canada as a full-fledged Security Council member. Heinbecker told the council that Canada supported new sanctions on Afghanistan because it continued to be a backer of terrorism, but stressed precautions were needed to protect civilians who had lived through two decades of war. "We believe that the Security Council has an important role to play in eliminating terrorism, and we welcome its continued determination to do so," he said. (UNSC 2000, 9) "We encourage the Council to address the conflict itself and to consider ways to hasten the end of the interminable war and the desperate conditions endured by the people of Afghanistan." (Ibid)

Less than 10 months later, the events of Sept. 11, 2001 focused the world on Afghanistan. The al-Qaida terrorists, who had found safe haven in Afghanistan, hijacked four American commercial airliners and turned them into suicide missiles, two of which destroyed the twin skyscrapers of New York's World Trade Centre, while one blew a hole in the Pentagon and another was driven skidding into the ground of a rural Pennsylvania field by its rebelling passengers. Canada has been absent from the deliberations of the Security Council since then. In April 2013, Baird ruled out another 
bid for a Canadian run to win a Security Council term, telling a House of Commons committee that the country was "focusing on other priorities." (Levitz) Harper and Baird made brief cameo appearances at the Security Council in September 2014 during deliberations on the world's response to the Islamic State of Iraq and the Levant, or ISIL, the new more radical al-Qaida offshoot that had gobbled up large swaths of northern Iraq and Syria and created an oppressive, horribly violent Islamist caliphate. Canada was on the verge of contributing special forces commandoes and six CF-18 fighter jets to the American-led coalition about to go to war against ISIL. At the invitation of U.S. Secretary of State John Kerry, Baird and Harper were asked to speak. On Sept. 19, in a short intervention of about 530 words, Baird pledged Canada's support to the cause, saying: "We must defend the firm and unyielding principles of human liberty and dignity that have withstood the tests of fascism and communism, and now terrorism. That is the test facing us today. We cannot afford to fail.” (UNSC 2014a, 27) Five days later, Harper pledged Canada's support to the Council in a speech of less than 400 words. "We will also continue to work with the Government of the United States, the Government of Iraq and our other friends and allies on a range of humanitarian, political and military assistance to those fighting this phenomenon in the region." (UNSC 2014b, 25)

And with that, Baird and Harper were gone. The permanent five of the United Nations General Assembly continued their weighty deliberations with their 10 temporary partners: Argentina, Australia, Chad, Chile, Jordan, Lithuania, Luxembourg, Nigeria, South Korea and Rwanda. 
It's nice to be invited, said Fortier, but guest appearances like those simply can't compare to the access a temporary members get during their two years on the Security Council. What's incontrovertible is that in the post-9-11 era, Canada has been "outside the tent" of the world's most powerful body, he said.

"These are very difficult times on the geopolitical stage, whether you're looking at Ukraine, whether you're looking at Iraq, Syria, whether you're looking at the situation of Russia vis-a-vis the member states of the European Union — there's a lot that's going on in the Security Council where Canada's voice is not being heard," Fortier said. "You can always intervene, but you don't participate in the deliberations. It's like night and day... you have daily meetings with the five permanent ambassadors of the five permanent members - the big boys. That is worth its weight in gold, I assure you." Canada had a role to play, whether as a bridge-builder, or as a helpful fixer, he said. "It's real. We did play that role ... but not today, unfortunately," Fortier added. “That doesn't mean that Mr. Harper is not pursuing Canada's interests. He's doing it how would I put it? — Like Frank Sinatra, doing it in his own way." 


\section{Chapter Three: Saving Mothers, Children and Dollars}

May 2014. United Nations Secretary General Ban Ki-moon is addressing a packed ballroom at Toronto's Royal York Hotel, where some of the world's leading health professionals are meeting to find ways to prevent the unnecessary deaths of newborn babies and their mothers in the poorest countries. So far, everything is going according to plan for Prime Minister Stephen Harper. But before this day is done, the UN chief will pull the rug out from under him.

Ban thanks the prime minister for his new five-year commitment of $\$ 3.5$ billion, announced a day earlier, to help improve maternal newborn child health in poor countries. It is known by the acronym $\mathrm{MNCH}$, and the secretary general urges other world leaders to pony up as well. This is Harper's signature foreign aid initiative. In addition to the UN chief, the prime minister has brought together a wide range of international players in health, development and politics, including the philanthropist Melinda Gates, the Aga Khan and Queen Rania of Jordan, as well as the heads of several major UN agencies and the World Bank. They all laud Harper for showing international leadership on an important development issue. For Harper, it is crucial to have the UN's public stamp of approval on this project.

Harper's Muskoka Initiative, as it is known, is specifically aimed at accelerating progress towards achieving two of the UN's eight Millennium Development Goals, or MDGs, that were established 14 years earlier at its major turn-of-the-century summit. They are reducing child mortality (MDG4) and improving maternal health (MDG5). Harper introduced this initiative in 2010 when he hosted the G8 summit in Ontario's Muskoka cottage country, his first big moment playing host to the world on his turf. He 
made an initial five-year, $\$ 1$.1-billion pledge on top of $\$ 1.75$ billion already being spent on the cause, and hoped to encourage visiting world leaders to contribute more. Later, in September 2010, Ban appointed Harper and Tanzanian President Jakaya Kikwete as the co-chairs of the new UN Commission on Information and Accountability for Women's and Children's Health, an oversight body charged with ensuring $\mathrm{MNCH}$ funds are properly spent. Harper has since elevated MNCH to the status of being Canada's "flagship" development priority.

But this flagship aid initiative has not been without controversy. Harper has also slashed overall aid spending, plunging Canada well below the UN target for aid spending by rich countries, and he banned all funding for abortion, triggering a firestorm of criticism. Canada's aid history has been troubled since the government started giving money to poor countries in 1950, but Harper has found new ways to cut foreign aid spending while attempting to maintain the image of a benevolent aid donor. His government clawed back aid spending commitments by simply letting hundreds of millions of dollars in funding lapse — or die — as projects sit unapproved on a minister's desk. Harper has also selectively chosen which UN goals he wants to pursue, and which to ignore, decisions that have once more been fuelled by a combination of political ideology and domestic political necessity.

Early on, Harper decided that none of Canada's MNCH money would go directly to funding projects that provided abortions as part of a family planning strategy. Those options would be aimed at preventing the deaths of the hundreds of thousands of women who die in pregnancy and childbirth each year and the 6.6 million children who die before the age of five. (DFATD 2014) The abortion ban sparked criticism from the 
leading British medical journal, The Lancet, and former U.S. Secretary of State Hillary Clinton, among others. "You cannot have maternal health without reproductive health. And reproductive health includes contraception and family planning and access to legal, safe abortion," Clinton said. (Blanchfield "Clinton pulls") As well, the Conservatives imposed a five-year freeze on aid spending to 2015 in order to slay the deficit after they were forced to spend billions in stimulus dollars to curb the effects of the 2008 global financial meltdown. That meant Canada's overall aid spending continued to sink well below the UN target of 0.7 per cent of Gross Domestic Product, to 0.24 per cent. (Blanchfield "Among Lowest")

But at this moment in May 2014, with Ban at the podium, those controversies are forgotten. Ban breaks into a story that he says he has never before told in public. It is a poignant personal departure from the formal businesslike tone that usually characterizes the South Korean diplomat's speeches.

"I have been known in my family, and everybody knows I am the eldest son ... in fact I should not have been. I should have been the third child. I had an elder sister, an elder brother, according to my mother, but unfortunately they died soon after their birth," Ban tells Harper's assembled audience. (CTV) When he was young, Ban explains, it was quite normal to see women and children in his poor village die in childbirth. "People accepted this as a fact of their life. Our food was not sufficient; women feared giving birth. What should have been the most joyful day was often the scariest or often the saddest day instead.” (Ibid)

Ban says that is what drives him to fight for the eradication of such needless deaths. That's why, he says, he launched his own UN initiative in September 2010 to 
improve maternal, newborn and child health after seeing so many more needless deaths across Asia and Africa. (Ibid) The crowd bursts into applause. In that moment, Harper is able to bask in the approving glow of the chief of the world's largest multilateral organization - one that he and his ministers have often criticized. But what the secretary general gives, he will soon take away.

Three hours later, Ban and Harper are standing next to each other at separate podiums for a final press conference to close the three days of meetings. As the first reporter to the microphone, I ask the two men whether Canada needs to increase its overall spending commitment for international development — notwithstanding Harper's generous targeted spending promise of $\$ 700$ million per year for the next five years for the $\mathrm{MNCH}$ program — to bring it closer to the 0.7 per cent of GDP target.

Canada originally adopted the 0.7 per cent target in 1970 as part of Pierre Trudeau's foreign policy review. As Trudeau was assuming power, his predecessor Lester Pearson was chairing the World Bank's 1969 blue-ribbon Commission on International Development, which made the recommendation that national governments should spend one per cent of GDP on foreign aid. Pearson's foreign minister, Paul Martin Sr., had made the same commitment in 1966. (Cohen 2003, 80) Trudeau eventually settled for a slightly lower 0.7 per cent target. In 1970's Foreign Policy for Canadians, Trudeau wrote: "The values of Canadian society, as well as the future prosperity and security of Canadians, are closely and inextricably linked to the future of the wider world community of which we are a part. It is thus important for Canada that we accept our fair share of responsibilities of membership in the world community." (Ibid) 
Meeting that target has since proven elusive for most developed countries, with only Scandinavian nations such as Denmark, Sweden and Norway reaching it. Canada has never met it, reaching an all-time high of 0.53 per cent of GDP in 1975 under the Trudeau Liberals. (Tomlin et al. 173) Aid spending sank like a stone under the Chrétien Liberals in 2000, plummeting to 0.25 per cent of GDP. (Tomlin et al. 168) Despite having an economy worse off than Canada's, Britain became the first G7 country to commit to meeting the target in 2013, something I point out to Harper and Ban in the preamble to my question. (Stacey)

Harper deflects the question, saying Canada targets its foreign aid spending at programs that produce results. "It's the philosophy of our government and, I believe, of Canadians more broadly that we do not measure things in terms of the amount of money we spend, but in terms of the results we achieve." (Blanchfield "summit wraps")

Then it's Ban's turn. He elegantly upends Harper, prefacing his remarks by saying he is grateful for Canada's continuing support to address humanitarian crises such as the civil war in Syria, which by any measure has been generous. However, Ban points out that the 0.7 target was also one of the 2000 Millennium Development Goals, and says he believes Canada has the ability to live up to that commitment, as well. "This overall agreed target should be met," he says, standing next to Harper. "I sincerely hope that the countries of the OECD and particularly G7 should lead by example." (Ibid)

Ban's comment threw a wet blanket over Harper's attempt to present Canada as a benevolent aid donor, reaching out to vulnerable women and children. Harper may have presented the Muskoka Initiative as a way of kick starting two stalled UN Millennium Development Goals — reducing the deaths of children and improving the health of 
mothers. But he selectively ignored another component of the MDGs by refusing to commit to the 0.7 -per-cent development target.

"If every developed country set and followed through on a timetable to reach 0.7 per cent by 2015, the world could make dramatic progress in the fight against poverty and start on a path to achieve the Millennium Development Goals and end extreme poverty within a generation," said the UN's Millennium Project's website. “The core inputs to development — teachers, health centres, roads, wells, medicines, to name a few — are eminently affordable if rich and poor countries alike follow through on their commitments." (Millennium Project)

The Lancet also took Harper to task for his overall lack of aid spending, despite his targeted \$3.5-billion MNCH investment. In a commentary published one week after the Toronto conference, it called on Canada to live up to the 0.7 -commitment it had made both in the 1970s and later when it committed to the MDGs in 2000. "It has been many years since Stephen Harper had so much unconditional love poured over him," said the commentary. "But there are good reasons to ask questions about Canada's magnificent promise." (Horton) First, The Lancet criticized Harper for not including reproductive health issues in its MNCH initiative - specifically abortion, saying they "had been dropped by a conservative government that, for example, saw the toll of over 20 million unsafe abortions as too 'divisive' to discuss." (Ibid) Secondly, the commentary said Canada "remains a long way from fulfilling its promise of 0.7 per cent" of GDP in aid funding. (Ibid) It said Canada's overall level of spending on aid had declined sharply since the government introduced its MNCH initiative, falling from 0.34 of GDP in 2010 to 0.27 in 2013. (Ibid) "Prime Minister Harper's commitment to mothers and children is 
generous and sincere," the commentary concluded. "But we should also say firmly and respectfully that the scope of his commitment remains too narrow, that he needs to deepen his financial promise still further if he is to meet the international commitments his nation has signed up to ..." (Ibid)

Stephen Lewis, whose two decades in the UN system have included being Canada's ambassador, the secretary general's special envoy on HIV-AIDS and deputy executive director of UNICEF, said no Canadian prime minister has come close to meeting the 0.7 per cent target. In Lewis's view, what makes Harper's approach "particularly objectionable" was his decision to impose a five-year freeze on aid to 2015 while the economy continues to expand. "It's just that Harper is causing a more calamitous decline than anyone who went before him," Lewis told me.

While the Harper government was making high-profile aid announcements with specially chosen international guests, a more insidious, less transparent set of aid cuts were taking place inside the newly amalgamated Department of Foreign Affairs, Trade and Development in 2014. Not only was overall aid spending being slashed, the government wasn't even spending the money it had allotted to help poor countries. Since 2013, hundreds of millions of aid dollars has been allowed to lapse. In 2013, the former Canadian International Development Agency failed to spend 13 per cent of its budget, $\$ 419$ million of the $\$ 3.14$ billion that Parliament had authorized it to spend on grants and contributions to poor countries and UN organizations. (Berthiaume) In November 2014, the first performance report was released for the newly amalgamated Foreign Affairs Department, which had formally absorbed the Canadian International Development Agency the previous year. It revealed that of the $\$ 917$ million that was available to spend 
on alleviating poverty in poor countries for the year 2013-14, only \$792 million had been spent. That left more than $\$ 125$ million in lapsed funding, or 14 per cent of funds budgeted to help the poorest countries. (Blanchfield "countries lapse")

That money is not simply kept by the department and rolled over into the next year's budget - it is returned to the central treasury, where it can be used by the government to pay down the deficit. Like a $\$ 20$ bill discovered in a pair of pants on laundry day, this is found money for the coffers of the federal government. In this case, the lapsed funding can be used to help the government balance its books in an election year to show taxpayers how well it is managing the economy. The NDP's development critic, Hélène Laverdière, was one of several people I spoke to who characterized what this meant: "The Conservatives are trying to balance the books on the backs of some of the most vulnerable people who need our support." (Ibid)

New Democrat foreign affairs critic Paul Dewar challenged Foreign Affairs Minister John Baird over the lapsed funding during testimony at a House of Commons committee in November 2013. "Why is it taking so long for the approvals from the department to get to you? Why aren't these being approved? The approval process from your bureaucrats seemingly gets stuck with you," Dewar asked the minister at the Standing Committee on Foreign Affairs and International Development. (Baird 2013b) Baird replied: “I don't make any bones about that. I don't wake up every morning with a desire to spend every single dollar that I can possibly spend.” (Ibid)

Roger Earnhardt, who retired recently after a 27 -year career at the now-defunct Canadian International Development Agency, said the phenomenon of lapsed funding was something he had never seen until the latter portion of his career when the 
Conservatives were in power. Based on the department's internal procedures, the only way to do that is with political direction, he explained in an interview. From 2000 to 2010, Earnhardt was CIDA's director general of multilateral development institutions, responsible for the flow of Canadian dollars to $\mathrm{UN}$ organizations and regional development banks. One thing he learned in all those years was to spend every last penny on what Parliament intended it to be spent on.

“There was always mechanisms in place to make sure we'd spent the money that was allocated to us," Earnhardt said. The concept of hundreds of thousands of development dollars going unspent was simply not something that happened in the department. "You can only do that if you deliberately want to because the agency is so good at spending money we're always within a couple of million dollars of our budget," he said.

Department officials would closely monitor the pace of spending, keeping a close eye in the five months leading up to end of the government's fiscal year of March 31. The agency's management committee would meet and indicate the projects for which money was likely to go unspent, he said. The plan would be to give those funds to a United Nations agency ahead of schedule, taking advantage of the fact that while Canada's fiscal year ended in March, while the UN managed its finances according to a regular calendar year.

"We would owe them a payment for the calendar year and we would just make it in March rather than in June, for example. It was a benefit to them because the earlier in the calendar year they got the money, the better it is for their planning," said Earnhardt. The key to doing that, without breaking any rules, was for department officials to get 
their minister's approval, in advance. Suddenly, said Earnhardt, the approvals stopped coming. "It hadn't been done before. It was really a deliberate manoeuver to cut back spending in an underhanded way because it's not announced in the estimates, it's not approved by Parliament. It's sort of reducing spending through a back-door mechanism, which isn't necessarily a legitimate way to go about it. It's not open," he said.

"That was a sign that more important to them was being able to reduce the deficit than to live up to any commitments they had in terms of the overall aid budget."

The Ottawa-based McLeod Group, an association of foreign policy experts that includes senior former public servants and diplomats, academics and members of civil society, has been unrelenting in its criticism of the Harper government for using the development agenda for partisan domestic political gain. One of its members, University of Ottawa political scientist Stephen Brown, told me that while he thinks spending money on young pregnant mothers and their babies in the developing world is a worthy cause, Harper's overall development strategy is fundamentally flawed. That's because the government is not increasing its overall aid budget, which means that its big ticket MNCH spending initiative will only reduce what can be accomplished in other areas. (Blanchfield "pledged \$3.5B") “We're focusing on symptoms and we're abandoning the underlying causes, which are poverty and inequality." (Ibid)

In the days leading up to the 2014 Toronto conference, the McLeod Group unleashed a scathing critique of Harper's MNCH approach. “Once again Canada's development co-operation policies are being driven by domestic interests, not the development outcomes and the results the government claims to be seeking," the group said a blog post. (Blanchfield "polarizes at home") The online commentary was titled, 
"Delusions about international leadership" and accused Canada of grandstanding and pretending to lead on an issue that has been on the international radar for two decades. (Ibid)

Dewar, the NDP's foreign affairs critic, said the government was deliberately showcasing $\mathrm{MNCH}$ to mask the fact it has cut overall development spending. "Overseas assistance development should be done in a way that has high impact with people we're trying to help," Dewar said. (Blanchfield "spending shrinking") "What the government's approach is, we're trying to use overseas development assistance for high impact for the promotion of the government." (Ibid)

International Development Minister Christian Paradis acknowledged that one of the goals of the MNCH initiative is to promote Canada's brand outside of its borders. During an interview in the spring of 2014, Paradis was enthusiastic and sincere about the need to tackle the problem. "We want to be a leader in this and we can do more," Paradis told me in his Parliament Hill office. "This is important for the taxpayers to fully appreciate how Canada is well-branded all around the globe." (Blanchfield "Paradis says")

Earnhardt said he started seeing cracks in Canada's stellar international brand, particularly in Africa, where he was once posted and visited regularly for CIDA. "I took part in numerous multilateral meetings over 10 years. I would say by the time of the end of that period, around 2010, our reputation was much weaker than it had been earlier on," he said. "I had people that I'd been in meetings with four or five years in a row, and they'd take me aside and say, 'What's wrong with Canada here? Why aren't you being supportive on this?"' Over his last decade at CIDA, Earnhardt regularly represented 
Canada at the replenishment meetings for the world's various regional development banks, particularly in Asia and Africa. Deciding each country's contribution for what would usually be a three-year spending commitment required attending two or three meetings before a closing international gathering where countries were expected to bring a final figure to the table in order to set the bank's budget. Around 2007, Canada started showing up without a number, Earnhardt recalled. "People would say, 'Why can't you come up with a number? Everybody else has done it.' " Eventually Earnhardt and his team would "muddle through" by offering up a figure with the hope they'd get it approved in Ottawa, which they usually did. Earnhardt recalled a 2009 meeting in Paris when that short leash became particularly uncomfortable. He had arrived at the final pledging meeting, without an actual pledge. His team managed to muddle through, but not before he was pulled aside by a senior international banking official. "When I came to the meeting and told the World Bank fellow chairing the meeting, he wasn't terribly pleased that we weren't able to deliver," Earnhardt recalled. "Privately, he wasn't pleased."

The need to place more value on taxpayers' money became a growing concern in international development circles at the turn of the $21^{\text {st }}$ century as corruption and waste had made donor countries increasingly skeptical. But it was two of Harper's Canadian neoconservative predecessors who really gave the prime minister the ammunition to pursue a harder-edged aid policy. Former Ontario premier Mike Harris and founding Reform Party leader Preston Manning co-authored a foreign policy treatise in 2007 as part of a series of books under the banner "Canada Strong and Free." They viewed 
Canadian aid policy as part of a broader, weak foreign policy that needed to be toughened up: "Canadians work hard for their money. They do not mind paying taxes for good purpose — and most would agree that alleviating poverty is such a purpose." (Harris \& Manning 69) With a fondness for italics to stress their argument, Harris and Manning questioned the need to fund the MDGs, which the UN Millennium Project estimated would require " $\$ 70-\$ 80$ billion each year" to meet the targets. (Ibid) "This in turn requires donor countries such as Canada to approximately double the amount they give as a share of GNP.” (Ibid) They said the $\$ 100$ billion spent annually across the globe on development "cannot be proven to be effective in relieving poverty." (Harris \& Manning 71) They said aid should be about "tools of wealth creation" and "promoting economic freedom" with more public-private partnerships and less reliance on governments. (Harris \& Manning 78) And they asserted: "As we have already said, the evidence showing that development aid has any effect in alleviating poverty or producing prosperity is inconclusive at best." (Harris \& Manning 79)

Finally, Harris and Manning took aim at the UN's call at the 2000 Millennium Summit for rich countries to meet the 0.7-per-cent-of-GDP target for aid spending. "Why adopt a random, analytically arbitrary monetary target rather than a seasoned, evidencebased target keyed to results? In addition to the oft-noted absence of any fiscal, macroeconomic, or empirical basis for this 0.7 per cent target, it is flawed from a deeper perspective," they wrote. (Harris \& Manning 112) “The commitment targets money to be spent; it says nothing of how, or well, it is used. Where is the incentive to improve, or even achieve poverty reduction or development when more aid money flows each year regardless of its effectiveness? This is the epitome of the preference for activity over 
results.” (Ibid) The arguments of Harris and Manning gave Harper the theoretical template to support his much more skeptical view of foreign aid.

There is no doubt that Canada has a troubled history of delivering foreign aid, and it is a badge of dishonour that the Liberals and Conservatives must both wear. Canada's best intentions and desires never lived up to the most altruistic of expectations of Canada's foremost advocate of foreign aid, Lester Pearson. In 1950, when he was Louis St. Laurent's external affairs minister, Pearson pushed for Canada's involvement in the Colombo Plan, the blueprint for economic development in India, Pakistan and Ceylon, now known as Sri Lanka. The decision to participate was controversial and divided St. Laurent and Pearson. (Tomlin et al. 156) But Pearson eventually convinced St. Laurent to participate.

When John Diefenbaker won power in 1957 by unseating the Liberals, he entrenched the idea of marrying Canadian foreign aid to its domestic economic interests. With the support of Saskatchewan wheat farmers he found a way to get rid of their massive surpluses. In 1956-57, food accounted for three per cent of overseas development assistance. Two years later, it mushroomed to 50 per cent. (Tomlin et al. 157)

When the Liberals returned to power in 1963, this time with Pearson as prime minister, the notion of "humane internationalism" was born. The idea was simple: it was about helping the world's poorest rather than finding outlets for Canadian exports. Canada's aid budget doubled in size on his watch. Pierre Trudeau continued the focus on the world's poor in 1968 when he succeeded Pearson. But the newly created Canadian International Development Agency, first led by young entrepreneur Maurice Strong when 
it was founded in 1968, was under pressure to focus on more advanced developing countries that would be better able to buy Canadian goods and services. (Tomlin et al. 158) "The commitment to poverty alleviation added substance to Canada's claim to be a responsible and constructive member of the international community," wrote historian Elizabeth Riddell-Dixon. (Riddell-Dixon) "Having a foreign aid program dedicated to humane internationalist objectives helped Canada, especially in the later 1960s, to distance itself from the United States and its war in Vietnam. In short, Canada's policies on issues of peace and economic development were geared first and foremost to forwarding Canada's own immediate interests." (Ibid) This 1960s and 1970s tension between humane internationalists - acting altruistically — and using aid simply as an extension of Canada's economic interests mirrors in many ways the current debate over the Harper government's current approach to aid. But there's a general consensus emerging among international aid observers that the pendulum has swung much farther towards Canada's self-interest under Harper's watch than in previous decades, when the broad principle of humane internationalism was more in vogue.

In 1975, the Trudeau government's five-year development strategy was released and emphasized helping the poorest of the world's poor. It declared that Canada "would harmonize various external and domestic policies which have an impact on developing countries, and ... use a variety of policy instruments in the trade, international monetary and other fields in order to achieve its international development objectives." (Ibid) The government also decided "the development assistance program will direct the bulk of its resources and expertise to the poorest countries of the world." In doing so, Trudeau also endorsed the 0.7 per cent target." (Tomlin et al. 183) His government also decided that 
the United Nations would play the deciding role in determining which countries received support, or "the hardcore least developed countries identified by the United Nations." (Tomlin et al. 158) This was the year that Canadian aid, as a percentage of GDP, reached its highest point at 0.53 per cent, but still not 0.7 (Tomlin et al. 173)

Canada's internal debate over foreign aid continued into the 1980s under Brian Mulroney's Progressive Conservatives. In 1987, the House of Commons External Affairs committee issued a report that made two key recommendations: it tied aid to human rights for the first time. It also called on the government to never let foreign aid dip below 0.5 per cent of GDP. (Tomlin et al. 160) But Mulroney and his external affairs minister Joe Clark ultimately rejected that spending floor. (Tomlin et al. 161) The arrival of 1989 marked the beginning of the end of robust foreign aid funding in Canada, a decline that continued under the Liberals; it also essentially marked the abandonment of the 0.7 -percent target, which would also be ignored throughout the Chrétien and Martin years. (Ibid) By 2001, Canada had the lowest foreign aid ratio, 0.21 per cent of GDP. (Hillmer and Granatstein 315)

"In the end no one really expects many countries to meet the targets anymore except for the Nordic countries and the Netherlands. They're not bad things to have, they're aspirational," said Earnhardt. But the targets still have one useful role, he noted: "You can use it to keep a lot of countries from sliding back."

The $21^{\text {st }}$ century dawned with new possibilities to improve Canada's and the world's troubled history in trying to alleviate poverty in underdeveloped countries. The economies of Canada and its western allies were rebounding from the cutting and slashing of the deficit fighting of the 1990s. Possibilities seemed ripe for adopting some 
evolving ideas that had gained momentum in international development in the 1990s better coordination among aid donors, partnerships and greater efficiency. (Tomlin et al. 201) Public concern about transparency and accountability meant a renewed approach to aid and development had become mandatory. (Ibid) After years of stagnation and decline, development policy appeared to be moving in new directions. When Canada hosted the Kananaskis 2002 G8 summit in Alberta, Prime Minister Jean Chrétien used it to refocus on Africa. The Liberals decided to double aid spending in 2002 for each year to 2010, something that then-finance minister John Manley said, "reflects the understanding that you cannot have a world of peace unless you address the world of need." (Ibid, 197) Chrétien pledged eight per cent increases each year to 2010. (Ibid, 175) Chrétien appointed Robert Fowler to be his G8 sherpa for the summit, which ultimately led to the new Africa Action Plan between the G8 and 53 other countries to assist Africa. (Ibid, 198) Chrétien pledged $\$ 500$ million for the Canada Fund for Africa, Canada’s contribution to the broader international plan. Canada's contribution was focused on several areas: economic growth, market access and public sector investment, governance and institutions, health, nutrition, agriculture, water and education. (Ibid) Canada also made huge, billion-dollar commitments to Afghanistan and Haiti, transforming them into its two largest bilateral aid recipients. (Ibid, 199)

Those Liberal aid initiatives provided fertile ground for Harper to cut and reconfigure aid for partisan purposes after he won power in 2006. The Harper government dined out on the Liberals' aid spending increases for their first four years in office, adopting them as their own before slashing the budget altogether. Harper's ministers, then-CIDA minister Bev Oda in particular, regularly took credit for the Liberal 
commitment at Kananaskis in 2002 before the Muskoka Initiative was unveiled in 2010 and aid was frozen two years later. (Smith 2009) Harper may have answered the growing calls in development circles for more accountability and transparency, but simultaneously ignored the calls for broader multilateral coordination or boosting overall aid spending to meet the UN's 0.7 per cent target. In 2010, after eight years of Liberal-promised aid spending increases had come to an end, Harper froze aid spending and ramped up his own marquee $\mathrm{MNCH}$ project.

Despite this, Harper has won support from some the world's leading international development advocates. They were some of his A-list invitees to the May 2014 conference in Toronto, including Melinda Gates of the Gates Foundation, Queen Rania of Jordan and the Aga Khan. But as big a fan as she is of Harper, Gates could not mask her concern when I reminded her of Canada's falling aid numbers in a recent interview. "I think Canada has honestly done a great job in some of these areas," she said. (Blanchfield "spending shrinking") "But we'd never want to see a country go back down or slide backwards (on overall aid spending) because it's just not the right message.” (Ibid)

One of the main beneficiaries of Harper's MNCH initiative was a small Ottawabased non-governmental health organization called the Micronutrient Initiative (MI). It was one of the four main multilateral partners chosen by the government to receive MNCH funds. In 2010, it was given a modest $\$ 75$ million over five years to deliver important supplements such as Vitamin A to poor countries as part of an effort to make young mothers and pregnant women healthier. At the November 2014 Francophonie summit in Senegal, Harper doubled that to a new five-year, $\$ 150$-million commitment to 2020. (Canadian Press 2014) Despite how well his organization has done under this 
initiative of the Harper government, Joel Spicer, the head of MI, carefully attempted to take the measure of the man when he and a dozen other aid executives got some privileged access to Harper in a Toronto hotel in April 2014 prior to the big three-day conference there a month later. Spicer has a long career in international development that has included stints at the United Nations and the World Bank, and which had taken him from West Africa and South Asia to Washington and Geneva. In his experience, he said it is rare for a world leader to make a commitment on a development issue and follow it through years later. (Blanchfield "polarizes at home")

"What struck me - because I was really looking for it — is that he's actually sincere; he's personally committed to it," Spicer told me. "He was saying, 'I deal with so many issues on a daily basis and this is one of the ones I actually think is important'.." (Ibid)

Spicer recalled how others around the table were asking themselves what was in it for Harper. "There was some discussion about to what extent was this opportunistic. It was very clear he was personally committed, that he felt a sense of injustice," he said. "The fact of the matter is: this is not something that would win an election." (Ibid)

Stephen Lewis couldn't agree more - no Canadian prime minister ever won or lost a federal election based on how much foreign aid they doled out to poor countries. But Lewis said Harper has burned so many bridges in the UN system, he almost had no choice but to look for a way to soften his image, to overcome the "negativism" he has generated towards Canada with the symbolic act of compassion that MNCH has represented. 
"I don't think anything Harper does is sincere," Lewis told me. "I don't think it has great domestic political benefit. I just think it makes life less embarrassing for Stephen Harper as he wanders in the councils of the world."

Whether Harper is using MNCH for domestic political gain doesn't matter to Anthony Lake, the chief of the United Nations Children's Fund (UNICEF). "I do not know his (Harper's) motives. I'm sure parts of them are of genuine passion for children," Lake said in an interview. (Blanchfield "pledges \$3.5B") "And a part of it is probably political. And that's a good thing. We are all trying to make these issues part of the political scene because there should be a popular demand for dealing with the welfare of children around the world." (Ibid)

Earnhardt said it is hard to criticize a government for championing the cause of underprivileged women and children in poor countries. But at the same time, "It's an easy one to champion." He aligned himself with other critics who said that the Conservatives were trying to soften their image with voters to reach new supporters beyond their traditional base. "It emphasizes things you see in Republicans in the United States, as well. You put emphasis on crime prevention, on security, on being tough on crime, and anti gun-control," said Earnhardt. "But I think there's a recognition that if you're going to get beyond a certain percentage of the population, they needed to show another side of the government. MNCH was one area that allowed them to do that."

But by deciding that none of the funds for the initiative would go to projects that included abortion, the Conservatives were also pandering to their grassroots base, he said. "Somewhere in the government they decided this was a time where they could show their 
credentials to those who were opposed to abortion and include that in the program," said Earnhardt.

The Conservatives didn't immediately trumpet that part of the package when they announced their plans for this signature initiative in early 2010. Rumors abounded regarding the abortion issue in the months leading up to the June 2010 G8 leaders summit in Ontario, but the government said little. On a visit to Ottawa on March 31, 2010 with her fellow G8 foreign ministers, U.S. Secretary of State Hillary Clinton addressed the simmering controversy head on. "I do not think governments should be involved in making these decisions. It is perfectly legitimate for people to hold their own personal views based on conscience, religion or any other basis," Clinton said when asked about the issue by a Canadian reporter at a press conference. (Blanchfield "Clinton pulls") "But I've always believed the government should not intervene in decisions of such intimacy." (Ibid) Clinton's host, then Canadian foreign minister Lawrence Cannon, remained silent, in a seat beside her. (Ibid)

It would take almost another month before the Conservative government would publicly confirm the policy of not funding abortion services in its showcase foreign aid initiative. Bev Oda, then the cabinet minister for the Canadian International Development Agency, confirmed the abortion-funding ban at a meeting of G8 development ministers in Halifax on April 26, 2010. Harper was forced to defend it the next day in the House of Commons. "Canadians want to see their foreign aid money used for things that will help save the lives of women and children in ways that unite the Canadian people rather than divide them," Harper said. (Smith 2010) "We understand that other governments, that other taxpayers, may do something different." (Ibid) 
One month later, and with just a month to go before Harper welcomed his fellow G8 leaders to Canada, the British medical journal, The Lancet, blasted the government in a furious editorial. It lamented the absence of emergency obstetric care in Harper's plan, along with any provisions aimed at improving access to safe abortion. "Sadly, this omission is no accident, but a conscious decision by Canada's Conservative Government not to support groups that undertake abortions in developing countries. This stance must change," the editorial said, pointing out how 70,000 women across the world died each year from unsafe abortions. (Lancet 2010) "The Canadian Government does not deprive women living in Canada from access to safe abortions; it is therefore hypocritical and unjust that it tries to do so abroad." (Ibid) The Lancet called on Canada's fellow G8 leaders to stand up to the abortion ban, but in the end they did not. "Although the country's decision only affects a small number of developing countries where abortion is legal, bans on the procedure, which are detrimental to public health, should be challenged by the G8, not tacitly supported. Canada and the other G8 nations could show real leadership with a final maternal health plan that is based on sound scientific evidence and not prejudice.” (Ibid)

Senior public servants inside CIDA opposed the no-abortion policy. Internal briefing documents prepared for Oda made it clear that access to safe abortions could save the lives of numerous women in developing countries. (Vastel and Olivier) "How can we make it happen?" was the heading of the document that was released under Access to Information. Then-CIDA president Margaret Biggs approved it. It listed "safe abortion services (when abortion is legal)" under a series of family planning services that might lower the number of women who die each year during pregnancy or childbirth - 
about 500,000 — as well as the nine million children who die before their fifth birthday. (Ibid) "Globally, complications after unsafe abortions cause 13 per cent of maternal deaths," the document said, adding that a maternal-health initiative promoting safe abortion methods would lead to "a significant decrease in the global number of unwanted births and of half the number of unsafe abortions." (Ibid)

For Stephen Lewis, Harper's position on abortion is proof positive that he's not sincere about his signature aid initiative. "Canada's reluctance to provide money for family planning, or any kind of sexual or reproductive health, and the ban on providing money on abortion, that diminishes significantly the validity of the initiative," said Lewis, who remains active in the UN system. "People are very, very suspicious about a northern country that doesn't take contraception seriously and doesn't take abortion seriously. These are two factors that plague maternal health."

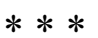

After winning his long-sought majority in 2011, Harper allowed his new foreign minister, John Baird, to trumpet his own aid project, this one also designed to generate a warm glow around the notoriously pugnacious Baird — just as Harper's plan to help poor children and mothers had softened the prime minister's steely veneer. Baird's personal aid cause became a firm commitment by Canada to help end the proliferation of child brides and forced marriages in poor countries.

Like the prime minister's MNCH initiative, Baird's plan to try to end the early forced marriages of young girls appeared suddenly on Canada's international agenda when Baird spoke at the United Nations in September 2013. It is a problem that the UN says affects 400 million women or girls in Latin America and the Caribbean, South Asia 
and sub-Saharan Africa. These teenaged brides are not only abused, but when they get pregnant, they and their babies face life-threatening consequences. Complications during childbirth have been singled out by the UN as the leading cause of death in girls in poor countries between the ages 15 and 19. (Blanchfield "Canada praised") Baird announced his new initiative in his 2013 General Assembly address, prefacing it with the government's combative new foreign policy mantra. "Here at the UN, Canada targets its efforts on securing tangible results for the human family," he said. "Canada's government doesn't seek to have our values or our principled foreign policy validated by elites who would rather 'go along to get along'." (Baird 2013a) He called early forced marriage "abhorrent and indefensible" and declared, as if there was some other alternative: "We condemn it." (Ibid)

In December 2013, I interviewed Baird at this office in the Foreign Affairs Department in Ottawa. I wanted to hear more about this initiative to save young women in the developing world from sexual violence and exploitation. It had been three months since Baird had announced the priority at the UN. Surprisingly, he had no specifics on what Canada would be doing to combat the child-bride problem. He vaguely offered up that there would be money for programs on some form of advocacy. (Blanchfield "Canada praised")

"We're just really starting from the ground on this," Baird told me. "There's room for government action, but it will require societal change from the ground up. We're just at a very, the early stages of this." (Ibid) Like Harper's MNCH plan, the one thing Baird could say categorically was that any pregnant young child brides wouldn't have access to abortion. "The reality is, what this initiative is about is stopping this from happening in 
the first place. It's like fire prevention," Baird explained. "In your fire prevention budget, you don't hire firefighters. You do prevention work.” (Ibid)

A senior United Nations official, who was well aware of the abortion controversy, was still extremely positive about the overall initiative. Susan Bissell is a Canadian who works as the associate director of the child protection branch of the UN Children's Fund in New York City. A few days before I interviewed Baird, Bissell told me she didn't think Canada's abortion ban diminished its international leadership on the issue because there were enough other ways for the government to make a difference. (Ibid) "We're trying to leave that off the table. We're talking about everything but that, frankly," she said, calling the issue "an obstacle to negotiate around." (Ibid)

Bissell had come to Ottawa to meet with policy makers in the offices of Harper and Baird, and left genuinely impressed with the deep level of understanding. To Bissell, they understood the overlapping complexities that encompassed health, justice and education. "Canada is the first government that I've talked to that sees those connections," she said. What Bissell was really hoping to see was a multimillion-dollar contribution to the fight against the exploitation of girls. (Ibid)

Within a year, Baird delivered $\$ 30$ million in new funding, but when he announced the last batch in November 2014, Canada's lack of commitment to the 0.7 per cent target once again reared its head. Baird was honouring Princess Mabel van Oranje of the Netherlands with the government's John Diefenbaker human rights award. Her organization, Girls Not Brides, was helping lead the fight against child brides in 60 countries. (Blanchfield "Tories urged") Like those invited to attend Harper's MCNH 
conference earlier in the spring, Van Oranje heaped praise on Canada for being a world leader on an important child welfare issue during an interview about her visit to Ottawa.

But when asked about Canada's overall aid commitment, she told me: "I think it's wise for rich countries to spend 0.7 per cent of their GDP on international development." (Ibid) She called that "a smart investment, and the amounts involved are not enormous." After all, she said, "We're talking about less than a per cent of all the wealth that we have, on development." (Ibid)

As for Stephen Lewis, he doesn't believe Baird is any more sincere about helping abused girls than Harper is about improving maternal and child health. "I know people praise John Baird. I thought he was a horse's ass as a minister, always posturing, always making pretentious speeches," Lewis told me, "using child marriage or sexual violence and seeing a political value in saying something good in the right place, at the right time. But there was no coherence around the policy. The incoherence around the UN is as much John Baird's doing as Stephen Harper's doing."

$* * *$

September 2014. Stephen Harper is back before the UN General Assembly, and to the surprise of many, he's making a heartfelt plea to help the world's most vulnerable. It is his third time addressing the assembly, and it is his first appearance since his 2010 failure to persuade a majority of its members to elect Canada to the Security Council. There's a war against Islamic State militants in Iraq and Syria raging, and unrest in Ukraine and the Middle East continues to boil. But tonight the prime minister wants to talk about the world issue that he says is "closest to my heart." (Harper 2014) He's here to make a pitch for his Maternal, Newborn and Child Health initiative. It's been almost 
five months since his landmark \$3.5-billion commitment and Harper wants others to contribute. "Saving the lives of the world's most vulnerable mothers, infants and children must remain a top global priority," the prime minister says. (Ibid)

But as Harper speaks, he is looking out into a chamber filled with empty seats. As the images appear in television cutaway shots that are broadcasting the address back to Canada, the hollowness of the chamber is pronounced. Some of Harper's political opponents begin to ridicule him on social media. "The Great Statesman PM commanded quite the audience at the UN yesterday," said Gerald Butts, the chief adviser to Liberal Leader Justin Trudeau, in a posting on Twitter the next morning (Huffington Post "Harper mocked") Some people watching it wonder if it is indicative of something more. "This is what the international community thinks of \#Harper: IRRELEVANT and a WASTE of time," tweets one viewer.

Harper presses on, making his case. He wants the world to join him, to join Canada in helping stamp out the scourge that is needlessly killing mothers and children. "I know we all have many competing priorities," Harper says, but to stop now, "would be a tragedy." (Ibid) Harper's commitment to his cause is genuinely heartfelt, and passionately delivered. He references his May conference in Toronto, and urges the international community to contribute money to the cause. It's just that the international community, in this moment, has taken a pass. As one tweeter says in the middle of Harper's speech: "CBC The National just showed another shot of the empty room at the UN. Even worse than the other photo." (Ibid) This superficial lack of interest in Harper's speech was coming to symbolize a lack of influence at the UN. 
After a career devoted to foreign aid, Earnhardt said he simply doesn't believe that the Harper government is the least bit interested in strengthening the international development system. "They don't see the benefit of a strong multilateral system except in so far as it is directly supportive of Canadian interests," he said. Core funds — not targeted spending like $\mathrm{MNCH}$ - are the lifeblood of international organizations. Targeting money to a specific program can weaken the agency's overall effectiveness over time.

"Those are the big numbers, and people remember those and say, 'Ah the government is responsive to this situation or that situation'," he said. "But some of the regular funding, very important for organizations doing good work, was being cut back and being lost over the longer term." 


\section{Chapter Four: Cluster Bombs}

January 1991. British Flight Lieutenant Richard MacCormac is in the cockpit of a Jaguar fighter jet that is streaking across a clear blue sky towards the coastline of tiny Kuwait. Iraqi army radar technician Moaffak Alkhafaji is a passenger in a truck travelling in a convoy of Iraqi soldiers, lumbering its way across the last expanse of their country's southern desert towards its border with Kuwait. Iraqi President Saddam Hussein's army invaded neighbouring Kuwait, and a 35-country coalition has mounted a military campaign to repel the Iraqi forces and liberate the tiny country. The coalition is operating under a United Nations mandate authorizing the use of force, led by the United States, and including a modest contribution from Canada.

MacCormac and Alkhafaji may be separated by the Kuwaiti-Iraqi border, and serving with opposing forces in the first Persian Gulf War. But at different moments during this pivotal month of the war, both of these men will experience the effects of a weapon that causes devastating and indiscriminate human carnage. When this war ends, they will emerge united, and join together in a new common cause, to rid the world of the horrific weapon that is about to forever change their lives.

MacCormac is flying along side a handful of British RAF bombers. He zeros in on a series of zigzagging trenches laden with Silkworm missiles, part of an air defence network that Saddam has embedded along Kuwait's Gulf coast. MacCormac and his comrades pull the trigger on a weapon they have never used before — not even in training - a volley of cluster bombs. Each cigar-shaped missile contains dozens of smaller submunitions, the size of baseballs, which spray over the ground below when their furiously spinning carrier missiles open in mid-air to unleash their deadly cargo. A 
generation later, MacCormac recalls being "thunderstruck" by the massive plume of dust that rose up from the ground below.

"Most of the guys in the formation were rather taken aback. I was struck by the amount of damage that was being done and the area that was being covered," he recalled in an interview. "We were quiet on the way back home because we were having a good think about what we'd seen. Somebody wrote in the authorization sheets, when we got back, 'That's a pretty nasty weapon.' General agreement from us at the time."

Far away in southern Iraq, Alkhafaji hears the sound of another group of jets screaming overhead as his convoy continues its southward advance. Seconds later, his truck is rocked by a series of explosions. Alkhafaji struggles out of his vehicle and staggers momentarily, emerging onto a burning landscape littered with dead and wounded comrades, before he collapses, clutching his bloodied left leg. What remained of Alkhafaji's leg was removed that day, and now the disabled rights activist has become an advocate for ridding the world of the weapon that made him an amputee. "It's a very dirty weapon," he told me. "Its effect is random. It doesn't care if the target is civilian or military." (Blanchfield "bomb victims")

A generation after they were first exposed to cluster bombs in a war in which they were enemies, MacCormac and Alkhafaji now share common cause to rid the world of the weapon. MacCormac retired from the Royal Air Force after 25 years, and in 2011 joined the Danish non-governmental organization, DanChurch Aid, where he leads its efforts to clean up the remnants of deadly cluster bombs in several countries. Alkhafaji formed his own NGO in 2003, after Saddam Hussein was driven from power in the 
second Gulf war. For the first time in Iraq, that created the space for civil society groups to exist. Alkhafaji called his organization the Iraqi Alliance for Disability. (Ibid)

Canada also took part in the 1991 Persian Gulf War, deploying CF-18 fighter jets to the Iraq coalition, but did not use cluster bombs. In fact, Canada has never used cluster bombs, but announced in September 2014 that it had destroyed its unused stockpile of them, a remnant of its Cold War arsenal. (Blanchfield "more testimony")

Cluster bombs are wildly inaccurate and unreliable weapons that have a track record of maiming and killing innocent civilians. They were first used during the Second World War but were more extensively used by the United States in the bombing of Vietnam, Cambodia and Laos in the 1960s. They were used in later conflicts by Israel in Lebanon, Western countries such as the U.S., France and Britain in the 1991 Gulf War, by coalition forces in the subsequent wars in Afghanistan and Iraq, and most recently by combatants in Syria and Ukraine. (CMC) A single large cluster bomb spreads hundreds of smaller, baseball-sized bomblets over a wide area. An estimated 10 to 40 per cent of them fail to explode immediately, which can leave them littering the landscapes of postwar countries for decades. They are an irresistible draw for children because of their bright colours. Farmers in poor countries inadvertently stumble upon them. That's how thousands of innocent people in two dozen countries have been maimed or killed by them. (Ibid)

Under the Conservative government of Stephen Harper, Canada was oddly, almost inexplicably, slow to back the UN treaty process that seeks to outlaw cluster bombs and stigmatize their use. It was a curious position for Canada to occupy, given the fact that it helped lead the world towards a ban of a similar weapon, the anti-personnel 
landmine, in the 1990s. Canada signed the UN convention to ban cluster bombs in December 2008, but would wait until March 2015 to ratify the treaty. In that time, Iraq has ratified the convention, as have other war ravaged countries such as Afghanistan, Congo, Lebanon and Laos. So, too, have most of Canada's NATO allies, with the most notable exception being the United States. China, Russia and Israel are also among the countries that have taken a pass on joining the convention. (Ibid) The delay also opened Canada up to widespread international condemnation over what was seen an egregious loophole in the law that ratified the treaty.

Like a growing number of international observers, MacCormac and Alkhafaji were concerned that the legislation Canada used to ratify the convention was flawed. They cite a controversial provision that allows the Canadian Forces to be involved in the use of cluster bombs in joint military operations with countries that aren't signatories specifically with its closest ally, the United States. MacCormac said he has issues with "the way the legislation appears to provide opportunities, loopholes if you like, even for Canadian involvement in acts that the Convention on Cluster Munitions itself expressly tries to suppress or forbid." Alkhafaji agreed. "It's not good that Canadians collaborate with other countries like the United States on support, or use ... or transfer cluster munitions because it's against the humans all over the world." (Blanchfield "raise questions")

The Harper government has faced widespread international criticism over the law that it enacted to ratify the United Nations Convention on Cluster Munitions. The cluster bomb saga was a case study in just how much the Conservatives have distanced Canada from its traditional acceptance of the UN treaty process - a major departure for Canada 
given its world-leading performance in crafting the treaty to ban landmines in the 1990s. In 1997, the Ottawa Convention that outlawed anti-personnel landmines became a signature moment in Canadian foreign policy, one that made some of world's most wartorn places discernably safer, and in the process allowed Canada to take a well-deserved bow. The international drive to ban landmines was closely associated with former foreign minister Lloyd Axworthy — a Liberal — who brought together his own coalition of international NGOs and civil society groups to lead what was known as the Ottawa Process.

That contrasts with the Conservative government's reluctance to firmly align Canada with the growing global movement to completely ban cluster bombs something the international community has noticed and condemned. One of Canada's most notable critics is the International Committee of the Red Cross, the scrupulously neutral organization that took the unusual step of going on the record with me about Canada's inadequate legislation. (Blanchfield "raise questions") Lou Maresca, a senior ICRC lawyer, said the most significant concern relates to a provision that would allow the Forces to transport or stockpile cluster bombs in joint operations. "The biggest concerns we have about the legislation are linked to the provisions on interoperability," Maresca told me from the ICRC's hilltop headquarters above Lake Geneva. (Ibid) "For us, that raises serious questions about the legislation and how that goes in parallel with the object and purpose of the convention, which is to eliminate any use of cluster munitions." (Ibid)

Norway has assumed the international lead on cluster bomb eradication, just as Canada did with landmines in the 1990s. The Norwegian-led campaign has been dubbed 
the Oslo Process. Norway's ambassador on the cluster bomb initiative, Steffan Kongstad, said he has noticed Canada's absence. "We all observe that Canada has, over the last years, has had different priorities, so there is less emphasis on multilateral work and also on disarmament," Kongstad said in an interview in Geneva. (Ibid) Kongstad also has questions about the framing of the bill for Canada's ratification of the treaty. "We would normally not comment on the internal processes in other countries," he said. "But I can say that we would not present such a law in the Norwegian parliament. It seems somewhat inconsistent with the purpose of the convention.” (Ibid)

Then-foreign affairs minister John Baird confronted the controversy surrounding the interoperability clause when the Senate Foreign Affairs and International Trade committee opened its hearings on Oct. 3, 2012. As the first witness, Baird testified that the government didn't want to do anything that would prevent senior Canadian military officers from being seconded to high-profile U.S. military exchange programs because of the convention. (Blanchfield "raise questions") This is particularly relevant for Canada because it enjoys a privileged level of access to military exchange programs with its powerful American neighbour, one that no other country can claim. Two retired generals who served as chiefs of the defence staff, Rick Hillier and Walt Natynczyk, participated in one of the most coveted U.S. military exchange programs: serving as the deputy commander of the U.S. Army's III Corps in Fort Hood, Texas. The sprawling U.S. army base is the size of large suburb. The posting allowed the Canadian generals to help command 60,000 U.S. personnel, about as many men and women serving in the entire Canadian Forces. Baird said it was in the government's interest to see that nothing got in the way of those top-level exchange programs. 
"I simply think it would be rather presumptuous of Canada to say, 'We are sending one person to work with these other 60,000 people, and here is a long list of things that we want to impose on you," Baird testified. (Ibid) As few as those opportunities were, Baird said the government was determined to protect them. "In our existing military co-operation, obligations in NATO, we have a small number, less than 0.001 per cent of Canadian Forces, on secondment or training missions with non-party state convention countries." (Ibid)

Steve Goose, the chair of the Cluster Munitions Coalition and the head of the arms division of Human Rights Watch, said nothing in the convention impedes Canada from participating in joint operations with the United States. Canada just has to swear off the use of cluster bombs, just as it did with the landmines treaty in 1997. "Canada's implementing legislation is nothing short of a disaster. It's by far the worst implementing legislation of any country that has signed the convention," he said in an interview in Geneva. (Ibid) American political scientist and anti-landmine advocate Ken Rutherford considers Axworthy and his fellow Canadians to be heroes, and he said those now fighting to ban cluster bombs owe Canada a debt of gratitude because of the ground breaking work with the landmines treaty. "Everybody was modeling the negotiations based on the Ottawa negotiations," Rutherford said. "Unfortunately on cluster munitions, Canada abdicated its moral leadership." (Ibid)

The movement to ban landmines began in the 1970s with an attempt by the International Committee of the Red Cross to update international humanitarian law (Tomlin et al. 209). The movement began in the United States, which demonstrated early support for anti-landmine efforts, even though it would eventually stay out of the 1997 
Ottawa treaty. Still, it is notable that there was early support for a landmine ban from both Republicans and Democrats. The ICRC was joined by several civil society groups in the United States, particularly the Vietnam Veterans of America Foundation led by Robert (Bobby) Muller, who along with U.S. Senator Patrick Leahy of Vermont persuaded U.S. Congress to pass a law that placed a moratorium on the export of landmines. (Ibid) Republican President George W. Bush first signed the moratorium legislation in 1992, and it was extended several times before Democratic President Bill Clinton signed it into law. (Ibid) The NGO coalition grew under Muller's leadership and expanded, incorporating the ICRC and the International Campaign to Ban Landmines (ICBL) headed by American activist Jody Williams. (Ibid) She joined forces with ICRC President Cornelio Sommaruga to lobby world governments to ban landmines. (Ibid) In 1994, Clinton used his UN General Assembly address to call for a worldwide ban on landmines. Meanwhile at the 1995 G7 summit, Prime Minister Jean Chrétien informally discussed a landmine ban with fellow leaders, though Canada had not officially joined the coalition. (Tomlin et al. 210)

A twist of fate led to Canada's much deeper involvement in the cause to ban landmines in 1995, when the UN mistakenly included it on a list of countries that had placed a moratorium on landmines. (Tomlin et al. 222) The mistake forced Canada into the anti-landmine camp, and that did not faze the Liberal government of the day. The Liberals quickly realized that any attempt to correct the record would do more harm than good to Canada's international reputation, so the momentum carried the country forward. (Ibid) In 1996, Axworthy took over the foreign affairs portfolio from André Ouellet, who was also an anti-landmine advocate. But Axworthy would take things significantly 
further, viewing landmines as an opportunity for "policy innovation" and a way to place his stamp on his new cabinet post. (Ibid)

It was not a partisan issue: the Liberals held a firm majority in the House of Commons but they found support from Dr. Keith Martin, a Reform MP who would later cross the floor to the Liberals, when he introduced a private member's bill that supported the ban. (Ibid) "The Conservative party were supporters at the time of the treaty, when we brought all the parties together," Axworthy recalled in an interview. (Blanchfield "Axworthy welcomes") "It wasn't a matter that this was some kind of Liberal gambit. It was something the entire country got involved in." (Ibid) Ottawa eventually convened an international strategy conference in October 1996, which Axworthy brought to a memorable close by challenging all to return to Ottawa by the end of 1997 with a signed convention. The Ottawa Process became a model for how to mobilize soft power and show international leadership, while costing the Foreign Affairs Department few actual dollars. (Ibid) The coalition of international actors rose to Axworthy's challenge when they returned to Ottawa to sign the treaty with great fanfare in Ottawa on Dec. 3, 1997. Two months earlier, in September 1997, the details had been hammered out in Oslo, Norway.

Exactly 10 years later, another large international gathering took place in Oslo, this time to find ways of ridding the world of another indiscriminate weapon - cluster bombs. Earl Turcotte was in Oslo as Canada's lead negotiator and the head of its delegation, to craft this new treaty, the Convention on Cluster Munitions. Canada was one of 49 countries that convened to discuss the creation of the treaty, similar to the Ottawa Convention. But the similarities ended there: Canada was no longer the leader on 
the cluster bomb campaign. "We were nowhere near the front of the pack on that one," Turcotte said in an interview.

But Canada was still making an active contribution at the outset, he said. In the months and years that followed, however, Turcotte would begin to gradually lose faith in his government's handling of the cluster bomb issue — so much so that he threw in the towel in early 2011, ending an otherwise successful public service career that spanned nearly three decades in Canadian development and foreign affairs. He decided he had no choice but to quit working for a government that he believed had undermined international law and his country's global reputation.

Turcotte had initially been thrilled to be a major part of Canada's contribution to the global effort to ban cluster bombs, which gained new momentum in 2007. This new activism gained strength in response to the Israeli bombardment of Lebanon at the end of the summer war against Hezbollah in 2006. When the shooting subsided, Israel left southern Lebanon littered with an estimated 100,000 unexploded bomblets. Jan Egeland, then the United Nations under-secretary general for humanitarian affairs, criticized Israel for its "completely immoral" use of the weapon, saying 90 per cent of the bombing occurred in the last three days of the war, when a resolution was in sight. (UN 2006) UN teams identified 359 separate cluster bomb strike locations with up to 100,000 bomblets, Egeland said. (Ibid) Israel had also used cluster bombs in Lebanon in 1978 and 1982. (Blanchfield "bomb victims") In fact, U.S. President Ronald Reagan once imposed a sixyear ban on cluster bomb sales to Israel after an investigation by Congress found that Israel had used them in civilian areas during the 1982 Lebanon invasion. (Tran 2007) 
Ahmad Mokaled discovered one of the unexploded remnants of that war on Feb. 12, 1999. It was the day he turned five. Ahmad's father, Raed, had brought him to a public park in the southern Lebanon town of Nabatieh, along with his older brother, then eight, to celebrate. (Blanchfield "bomb victims") It was one of the first sunny spring days of the year, and Ahmad sprinted into a group of children to join the revelry. His eye was drawn to a tiny, brightly coloured object, a cluster bomb submunition that had been dropped on his country long before he had been born. Ahmad reached down to pick it up, and the explosion instantly ended his short life. (Ibid)

"I call this weapon — the cluster bombs — a blind weapon," Mokaled told me in Geneva. "It cannot choose. They throw it everywhere ... Sometimes the Israelis throw a cluster bomb that looks like a toy." (Ibid) The Harper government was a steadfast, unequivocal supporter of the Israeli military's campaign against Hezbollah in Lebanon during the 2006 summer war — the conflict that had broken out as I travelled on Harper's airplane for the first time following his maiden election victory. Mokaled had some advice for the Canadian government on its controversial ratification bill. "I want to send a message to the politicians of Canada," he said. "Think on our children, like you think on your own children. Protect the children around the world (from) war, like you protect your own children." (AOL Video)

In May 2008, Turcotte was once again in the lead of the Canadian delegation to the 10-day international conference in Dublin, Ireland that was putting the finishing touches on what would become the Convention on Cluster Munitions. Turcotte worked late into the night, helping craft the wording of a new section - it would become Article 21 of the treaty - that allowed parties to the convention to take part in joint military 
operations with those that were not. A little over six months later, on Dec. 3, 2008, the convention opened for signatures in Oslo. Canada was one of more than 90 countries to sign the convention. As it turned out, it was the $11^{\text {th }}$ anniversary of the signing of the Ottawa Convention to ban landmines. But when Turcotte returned to Ottawa, he found the signed text of the new cluster bomb convention did not sit well with the government.

Even though senior bureaucrats had approved the proposed Dublin wording, they started hedging when they began examining the nitty-gritty of the text they had approved from Ottawa, he said. Military officials in particular questioned whether this new international convention would affect the Canadian Forces' ability to be part of a joint operation with the U.S.

The fallout over this issue would ultimately cost Turcotte his Canadian public service career, because he simply couldn't stomach what his government was about to do next. "As soon as we got back to Canada, we got involved in a heated debate about what the implications would be for joint operations," he said. The Department of National Defence was worried that Article 21, as written and agreed to by Canada when it signed the convention, severely hampered the military's ability to take part in joint operations with American forces. DND proposed wording that would permit Forces personnel to be involved in the use and transport of cluster bombs in joint operations. Turcotte said he saw that as contrary to the spirit and the word of the convention.

"We had interdepartmental debates. I had great support from my bosses at Foreign Affairs for two years," he recalled. What changed, he said, is that his senior managers came around to DND's position after two years of infighting. "I can only 
speculate that this decision — I am certain this decision — was taken at the political level," Turcotte said. "We lost and DND won. Simple as that."

Turcotte found this out in December 2010 and he issued a conscientious objection. He asked that his name be removed as the department's contact on the draft legislation because he couldn't in good conscience support it. Over the Christmas holidays, he considered his next moves. "I had done everything in my power to advocate inside public service to have domestic legislation that would be up to standard," Turcotte said. "But I couldn't advocate publicly, so the only way to advocate publicly was to leave the public service so I could openly disagree with what the government was about to do, and subsequently has done."

This wasn't the first time the Defence and Foreign Affairs departments went to war over the ban of such a weapon. It had happened in the 1990s during the antilandmine campaign. Then-foreign affairs minister André Ouellet and then-defence minister David Collenette had their own turf war in 1995 over whether Canada should join the growing tide to ban landmines. (Tomlin et al. 231) Collenette didn't want them banned until an "effective and humane alternative" could be found. (Ibid) But Ouellet decided to push ahead. He took advantage of the fact that the U.S. was going to put forth a UN resolution on a moratorium on the export of landmines, and had asked Canada to be a co-sponsor. That coincided with the UN mistakenly including Canada on its list of countries that had already agreed to an export moratorium. On Oct. 11, 1995 Ouellet wrote to Collenette saying that he wanted to announce a Canadian moratorium and cosponsor the resolution. (Ibid) Collenette reluctantly agreed, but insisted this would be as far as the military would go. (Ibid) When Axworthy took over the portfolio in 1996, his 
predecessor had effectively laid the groundwork for the landmine treaty initiative that followed.

Meanwhile, Canada's efforts to support a similar ban on cluster bombs moved at a snail's pace in the decade and a half that followed. In the fall of 2012, almost four years after Canada signed onto the convention, the Conservatives finally introduced a bill to ratify it. It was tabled in the Senate, not the House of Commons, the usual route for new legislation. Clause 11 of Bill S-10 outlined the interoperability provision that Turcotte and many others found so offensive. It allowed Canadian Forces personnel who were on joint operations with non-party states to the convention to:

- direct or authorize an activity by the armed forces of a non-state party that may involve the use of a cluster munition ...

- expressly request the use of a cluster munition ...

- use a cluster munition or undertake another prohibited activity while on secondment, attachment or exchange with the armed forces of a non-state party. (Library of Parliament)

Turcotte, who had formidable experience in the technical aspects of the convention that he helped create, testified in October 2012 as a private citizen before the Senate committee examining the bill. Free to speak his mind, he took laser-like aim at the flaws he saw in the bill — and promptly got into a verbal scuffle with a Conservative senator. Turcotte said Canada was poised to "set a dangerous precedent" that undermined international humanitarian law with Article 11. "This would be a betrayal of the trust of colleagues in other countries who negotiated the convention in good faith, a betrayal of Canadians who expect far better from our nation and, worst of all, a complete failure to 
do everything we can to prevent more needless deaths and suffering among innocent men, women and children," he testified. (Turcotte 2012) "I challenge the government to identify any other state party or signatory that is giving its forces carte blanche, in its own words, to aid, abet, conspire and assist non-party state forces with the commission of acts predicted to states parties." (Ibid)

That raised the hackles of the now ex-Conservative Sen. Pamela Wallin, who curtly kicked off her round of questioning by telling Turcotte: "I am a bit troubled by your tone. You suggested ... that somehow Canada's military men and women are looking for a back door to find a way to use these munitions." (Wallin 2012) Wallin was a little more than a year away from being booted from the upper chamber along with two other fellow Conservatives, Mike Duffy and Patrick Brazeau, at the height of the Senate expenses scandal. But on this day, the former television broadcaster and diplomat was still a trusted member of the Conservative caucus and a fierce partisan.

Turcotte held his ground, saying he had nothing but the greatest of respect for the Canadian Forces. He told the senator that his father served three years overseas during the Second World War. He said 20 of the 28 NATO countries had signed the convention. "We have a piece of legislation that is radically different from what the U.K., France, Germany, the Netherlands, Belgium, Norway and many other NATO allies have," he said. (Turcotte 2012)

But not, as Wallin pointed out, the United States. Indeed, Wallin affirmed the notion that Prime Minister Stephen Harper had emphasized in the past: that Canada's foreign policy interests did not lie exclusively with a multilateral institution such as NATO, but in its core bilateral relationship with the United States. "We are allowed, with 
our largest friend and ally, to view the world differently," she said. "As a Canadian, I do not want to forfeit that right to view the world differently or use my moral suasion to change their mind.” (Wallin 2012)

Wallin was giving voice to a principle of the Harper government's foreign policy: that it was clearly placing its bilateral relationship with its closest ally — the United States - above any broader sense of multilateral obligation, especially the UN. It represented a 180-degree pivot away from the human security agenda of the Axworthy era, which would have placed the welfare of civilians in a post-conflict country at the forefront. Yet, it has become increasingly clear since the 2009 arrival of Barack Obama in the White House that as the Harper government moves to align itself more closely the U.S. on the underlying security issue that is represented by its cluster bomb stance, it certainly isn't paying dividends in other areas. As Burney and Hampson point out in their book, Obama's decision to delay approval of the Keystone XL pipeline - which would be a major feather in the Harper government's economic cap — has been an ongoing irritant in the Canada-U.S. relationship. (25) Obama has turned a deaf ear to the Canadian arguments that the 80,000 barrels of day of Alberta oilsands crude that would be pumped to the U.S. Gulf Coast would replace imports from unfriendly Venezuela, and he's questioned whether the oilsands are contributing to greenhouse gas emissions. (26) And Hampson and Burney also suggest that the Obama administration somehow thwarted Canada's 2010 bid for the Security Council because its support "was noticeable by its absence.” (27)

The cluster bomb bill passed through the Senate without amendments in late 2012, as the Conservative majority outvoted proposed changes put forth by the Liberal 
members on the committee and strongly supported by some witnesses. The International Committee of the Red Cross proposed specific changes to the wording in Clause 11. But Bill S-10 remained as it was drafted. It was referred to the House of Commons, where it would continue to languish.

\section{$* * *$}

Turcotte returned to Laos in 2012, where he would work for two years as a technical adviser on cluster bombs for the United Nations Development Program. Turcotte had previously worked for several years in the 1990s in the tiny, landlocked south Asian country for the now defunct Canadian International Development Agency. It was there and in neighbouring Cambodia where he first met the young victims of cluster bombs, and was deeply moved by their suffering. (Blanchfield 2011)

Laos, a country of six million, suffers from the heaviest cluster bomb contamination of any country in the world, per capita. Between 1964 and 1973 during the Vietnam War, American B-52s dropped 270 million fist-sized bomblets on Laos, 80 million of which failed to explode. These rolling thunder air attacks saturated the Ho Chi Minh trail — the famed, North Vietnamese communist supply route - a part of which snaked through the dense Laotian jungles. Decades after the covert American bombing campaign, cluster bombs remain a dangerous hazard in Laos. The weapons have wounded or killed 20,000 civilians here since the Vietnam War ended four decades ago. (Blanchfield "Laos asks")

Six months after the Senate hearings ended in Ottawa, I was in the Laotian capital of Vientiane, speaking with a young cluster bomb victim. Phongsavath Manithong told me about the day he turned 16 . He was walking to school in his home village of 
Vinegthong, in central Laos, when a friend handed him a small metal bulb that he'd found by the side of the road. When Phongsavath tried to pry it open, it exploded. Five years later he was blind, and without hands. (Blanchfield "Young Laotians")

"We are not angry at the American government," Phongsavath said, seated on a couch in the Cope Centre, a government-run health and rehabilitation centre that also houses a small but powerful museum that poignantly illustrates the reality of the cluster bomb problem. "Many American people, they did not know what happened in Laos."

Above us, mobiles depicting dozens of cluster bomblets dangled from the ceiling in a chaotic constellation amid forms of prostheses that have been used in Laos over the years - improvised wood and metal contraptions that appeared as though artifacts from the Middle Ages. "We need more help from the American government. They are a rich country," Phongsavath said. "That's not enough to help the disabled people, the survivors." (Ibid) The United States was the leading international donor to the \$30million annual effort to help rid Laos of its cluster bomb infestation and help its victims cope.

Several Laotian government officials told me in the spring of 2013 that they wanted Canada to do more to help Laos clear its contaminated countryside of cluster bombs and address the needs of its many young victims. They told me that a year earlier, in 2012, Canada had cut its funding to the annual international effort to help Laos cope with its cluster bomb problem. Canada had contributed more than $\$ 2$ million between 1996 and 2011. (Blanchfield "Laos asks") In Vientiane, the normally closed communist government granted me hours of interviews with top officials. They were generous with their time and provided voluminous amounts of background, history and context. With 
unfailing politeness, they also emphasized this message: tell your country to start funding our unexploded ordnance sector again.

"I cannot say exact figures, but as much as possible as the government can afford," said Bounheuang Douangphachanh, a senior minister and chairman of the Laos government's unexploded ordnance agency. (Ibid) "We also would like to ask Canada to continue its support to the UXO sector in Laos." (Ibid)

Maythong Thammavongsa, a senior foreign ministry official, said that without international assistance it would be difficult for Laos to afford the level of bomb clearance, mine-risk education and victim assistance that it needed to grow his country's mainly rural farming economy. "I know that Canada is one of the strong supporters of humanitarian disarmament and for banning weapons that cause unacceptable harm to civilians. I hope that Canada will continue to provide valuable assistance," he said. (Ibid)

Over at UXO Lao, the country's national cluster bomb clearance agency, deputy director Wanthong Khamdala moved his index finger up and down a chart of figures, coming to rest on the column on Canada: "2007 to 2009, three years, there's no support," he said. "In 2012, we have no support from Canadian government, too," he said. (Ibid)

We strolled to the covered front porch of his office, where a large decommissioned cluster bomb case sat on a set of stilts, as long as Wanthong was tall. He said the missile once held 670 bomblets — "bombies" are they're called in Laos -which likely means that as many as 200 from this one bomb failed to explode. "Maybe there's some other internal issue the Canadian people consider more important to resolve," he said. "But I'd like to request to the Canadian government to consider again to support." (Ibid) 
The message of desperation was reinforced by international organizations, including the British clearance agency MAG, which had been active in Laos for two decades, as well as the head of all United Nations operations in the country, and Minh Pham, a Vietnamese-born American citizen whose family was evacuated in 1975 from Saigon as the war ended in U.S. defeat. How long could it take to rid Laos of cluster bombs? "It might take a few centuries at this rate, at the level of spending," said Minh. (Ibid)

All of these Laotian voices were included in my reports for The Canadian Press, which appeared in the summer of 2013. But there were no Canadian voices. While I was in south Asia, Ottawa banned Canadian diplomats based in nearby Bangkok, Thailand, which has jurisdiction for Laos, from talking to me on the record. (Ibid)

A few months later, in October 2013, Baird travelled to Laos with money in hand. He announced \$1 million to help fund unexploded ordnance clearance operations in Laos. For his photo-op, he chose the Cope Centre. Who would get the money? It would be split evenly between UXO Lao and MAG, the two organizations in my reports. The money would be administered in trust by the UNDP. (Blanchfield "Baird to travel") The announcement was just in the time for the resumption of parliamentary hearings on the cluster bomb bill, this time before the House of Commons foreign affairs committee. Baird indicated a willingness to entertain opposition amendments to the bill. (Ibid)

Back in Ottawa, the minister conveyed some emotional distress over his recent trip to Laos. Baird told me outside the hearing room after he had testified that he was deeply moved by his trip to the Cope Centre's medical ward. "There was a baby — a baby — who had lost its entire leg," he said, pausing briefly to answer some questions. 
"There was a 72-year-old man getting rehabilitation therapy with his prosthetic leg, and then everything in between." (Ibid)

For all of his emotional rhetoric, Baird and the Conservatives would remain unconvinced by the coalition that wanted to see amendments to the bill. In December 2013, the Commons hearings would come to an end, and the bill would be amended in the slightest way possible - the Conservatives agreed to the removal of one word from the contentious Clause 11. (Blanchfield "Tories change") It was an amendment proposed by the Conservatives, and agreed to by the NDP and Liberals after the government majority on the committee shot down a series of opposition proposals. The Conservative amendment removed the word "using" in a key part of the clause, but retained it in other sections. That meant that Canadian military personnel were clearly prohibited from directly using cluster bombs, but it did not completely rule out being indirectly involved in their use in a joint operation with the United States. (Ibid)

That final round of Commons committee hearings exposed a divide within the Canadian Forces itself over cluster bombs. Walter Dorn, a professor at the Royal Military College of Canada, urged the government in his testimony to amend the "obnoxious portions" of the bill. (Blanchfield "open mind") Dorn said that the interoperability clause "opens a gaping loophole, one big enough to fit planeloads of bombs." (Ibid) He said the legislation, as written, undermined the purpose of the treaty and set a bad example for other countries. "Canada should, instead, set a good example for the ratification of this important global arms control measure by closing the legislation's loophole and making sure no Canadians are authorized or forced to assist, direct, aid and abet or conspire with others to use cluster munitions," he testified. (Ibid) Dorn was in a unique position to 
speak his mind - unlike Turcotte who had to quit the government over the issue because under the terms of his employment as a professor within the military, he had the academic freedom to do so.

Retired general Walt Natynczyk, one of the two former chiefs of defence staff who benefitted from one of the highest-level U.S. exchange programs, testified in favour of the government's position. At the time of his Nov. 21, 2013 testimony, Natynczyk was the president of the Canadian Space Agency, and about a year later, the Conservatives appointed him deputy minister of the Veterans Affairs Department. As part of his U.S. exchange program at Fort Hood, Natynczyk deployed to Iraq as the deputy commander of American forces in 2004. That was the second war in which the U.S. had used cluster bombs on Iraq.

British pilot Richard MacCormac and his comrades had joined their American allies in dropping cluster bombs during the first Persian Gulf War in 1991 to repel Saddam's invasion of Kuwait. Between May and August of 2003 during the second Gulf war, the British again joined the Americans in dropping cluster bombs in their battle against the growing Iraqi insurgency. (Blanchfield "bomb victims") In all, the U.S. and Britain dropped an estimated 74,000 cluster bombs on Iraq — bombs that spewed 22 million baseball sized submunitions, mostly in the country's southern region near the Kuwaiti border, where one of them transformed Moaffak Alkhafaji into an amputee and one of the world's most compelling anti-cluster bomb advocates. (Ibid)

Natynczyk reminded the committee that when he was the top Canadian soldier in 2008, he signed an order prohibiting the Canadian Forces from using them. (Natynczyk 2013) Still, he said, the Canadian Forces personnel needed the protection afforded by 
Clause 11 of the bill because it would protect them against criminal prosecution if they were involved in the use of cluster bombs during a joint operation with an ally, especially the U.S. "From my perspective, I believe article 21 enables our forces to remain fully interoperable with the U.S. armed forces. This comprehensive level of cooperation is a unique strategic advantage for Canada," he told the MPs (Ibid). "The interoperability clause of the convention strikes a fair balance between profound humanitarian principles on the one hand, and Canada's security realities on the other." (Ibid)

Natynczyk pointed out that certain Canadian allies - a clear reference to the Americans - were not in favour of the cluster bomb ban because they were dealing with "major geostrategic security concerns that we, in Canada, are not faced with." He specifically pointed to South Korea, where cluster bombs were needed to protect the frontier against North Korea. (Ibid)

Natynczyk testified that while he was the second-in-command to U.S. forces in Iraq, he was not aware of any cluster bomb use that occurred on his watch, but he said they could have been used without his knowing. (Blanchfield "Natynczyk defends")

"I can say to you with confidence that I was never aware that cluster bombs were actually stocked in theatre, or that I participated in planning for their use or in fact authorized their use," Natynczyk said. (Ibid) "I had none of that experience whatsoever. However, unwittingly, I could have done so, and I could have participated in activities without my knowledge that assisted in the use of cluster munitions. But I would not have known it at that time." (Ibid)

U.S. Marine Corporal Travis J. Bradach-Nall likely didn't know there were cluster bombs in Iraq when he joined his comrades for what his family was later told was 
a "mine clearing operation" near the city of Karbala on July 2, 2003 - the last day of his 21-year life. After obtaining his service records from the U.S. Department of Defense a year later, his family found out a weapon that was manufactured in his own country and dropped by his own comrades had killed him. "I knew nothing about clusters, but had two brothers that know about this. One is an attorney, and he decided he wanted to get all the paper work on what happened. He went through FOI (Freedom of Information). He got the accident report, the pictures and everything," Louise Bradach, the deceased Marine's mother, said in a telephone interview from her home in Palm Springs, California.

In 2007, Bradach joined the international coalition that was forming to ban cluster bombs. She was aware of Canada's position, the one espoused by Natynczyk, that its military needs to remain interoperable with the U.S. "That's just a piece of garbage," she said. "If you ask the kids on the ground, what do you think? If you actually had to deal with it, that would be insane. So the government has to really know what's going on, look at the percentage that are civilian casualties, look at what it does to the troops - the weapon is hideous."

Canada should be upholding higher standards than the U.S. and should not allow any "loopholes" to stand in the CCM, she said. Canada should tell its allies: "We will not use it, we will not transport it and we will not hold it for you, we will have nothing to do with it - no loopholes. You open it an inch, it opens a mile."

In her years of activism, Bradach said she learned a few things about Canada, including how it led in the global ban on landmines, and how it has gone from leader to laggard in the way it has dealt with cluster bombs. 
"I always think of Canada as the nobler country in a way," Bradach said.

"We (the United States) are a really great country, but we seem to be so frightened of anybody taking things from us or treading on us. It just seems like Canada is less damaging to other countries.

"I don't want to see you going the way we've gone."

The Conservatives cleared the last major legislative hurdle on ratifying the convention when Bill C-10 received Royal Assent in late 2014. On March 16, 2007, they had formally served notice that they were ratifying the Convention on Cluster Munitions by issuing a press release that said Canada was helping to "save lives" with a contribution of \$2.4 million to mine clearance. (Blanchfield "Canada ratifies") Turcotte said the bill did not live up to the spirit and letter of convention, and that Canada would be "held to account by the international community, other states parties, civil society and UN agencies" on how it performs.

There may have been a long delay in ratifying the treaty, but in one way the Harper government was active — behind the scenes — on the cluster bomb file: it was working to keep the Palestinians from joining the CCM. On January 23, 2015, the UN filed notice of Canada's formal objection to a decision by the Palestinian Authority to join the Convention on Cluster Munitions. "Canada considers the declaration made by the 'State of Palestine' to be without any legal validity or effect," stated the notification of Canada's position when it was posted online by the UN. (Blanchfield "Palestinian attempts") The Palestinians had won non-member observer state status at the UN General Assembly in November 2012, an initiative that Canada deemed provocative and voted against. (Ibid) The Palestinians decided to join the CCM as an expression of their 
newfound status in the UN, and Canada decided to formally oppose that move one week later in keeping with its steadfast opposition towards enhanced Palestinian status within the UN.

New Democrat foreign affairs critic Paul Dewar questioned how the government managed to find the time to object to the Palestinian action — which he defended as legal — when Canada had other important international business on its plate. "The Conservatives should focus on ratifying Canada's commitments on the Convention on Cluster Munitions," he said, "rather than trying to keep others from joining this important international treaty." (Ibid) 


\section{Chapter Five: Israel and the Middle East}

July 25,2006 . Israel's war on Hezbollah in Lebanon is in its $14^{\text {th }}$ day, and for nine of them bombs have been falling in a narrow five- to seven-kilometre belt of land just north of southern Lebanon's border. (DND 2006) The Israeli Defence Forces has designated this patch of land just over its northern border as a "Special Security Zone." (Ibid) Three dozen Lebanese villages, two dozen United Nations observation posts, and several Hezbollah positions lie within the zone. (Ibid) The UN Patrol Base Khiam is one of them. The fortified two-story building with an underground bunker sits in a compound ringed by razor wire and perched high atop a hill, looking down on southern Lebanon and four kilometres further south, on Israel itself. The base was established in 1978 by a UN Security Council resolution that confirmed the withdrawal of the Israeli military from south Lebanon. (Ibid) A pair of Hezbollah positions lie 200 metres from Khiam, one to the north, another west. The militant group started this war two weeks earlier, when it managed to capture two IDF soldiers along the border after it started shooting rockets into Israel. (Ibid) On that day, Prime Minister Stephen Harper sparked heated criticism in Canada when he called the Israeli response - a massive aerial bombardment that was later followed by a ground offensive — "measured." (Blanchfield "measured response") The Conservative government was accused of taking sides and unfairly favouring Israel in its ongoing, unresolved conflict with the Palestinians. Two weeks later, the prime minister would set off more criticism with his initial reaction to the death of a Canadian peacekeeper and three of his UN colleagues after a massive bomb dropped by an Israel Defence Forces warplane crushed their bunker. (DND 2006) 
Forty-three-year-old Major Paeta Hess-von Kruedener - "Wolf" to those who knew him — was a gregarious, mustached paratrooper with the Princess Patricia's Canadian Light Infantry, a married father of a grown daughter and stepson. (Day 2013) His two decades in the Canadian Forces brought him to Cyrus, Bosnia and Congo, and he'd trained with the famed U.S. Green Berets. (Ibid) Hess-von Kruedener had arrived in the Middle East the previous autumn to work with the UN Truce Supervision Organization, or UNTSO, based in Jerusalem, and was assigned to Patrol Base Khiam. He was part of a four-person team, along with officers from China, Finland and Austria. They all died together there on July 25, 2006.

The Canadian Forces Board of Inquiry that examined Hess-von Kruedener's death documented his final hours in a 66-page report. It noted that the "clashes between the IDF and Hezbollah escalated to the point that there was a large scale protracted land incursion into South Lebanon by the IDF," with "no traditional military front" and "pockets of operations.” (DND 2006) On the day of the fatal bombing, Hess-von Kruedener's base was hit by three waves of Israeli bombardment, including four $155 \mathrm{~mm}$ artillery rounds that landed in the base compound at 6:29 p.m. (Ibid)

UN peacekeeping leadership decided that they would withdraw their four people from Patrol Base Khiam the following morning at 7 a.m. (Ibid) Meanwhile, rockets continued to fall. Radio transmission from Patrol Base Khiam reported "firing close" to it at 7:15 p.m., 7:16 p.m. and 7:17 p.m. (Ibid) At 7:25 p.m., a nearby UN patrol base transmitted the evacuation details to Patrol Base Khiam. Five minutes later, according to the BOI, "Patrol Base Khiam failed to respond to a scheduled radio check." (Ibid) 
Within 40 minutes, a recovery team from a battalion of the Indian army was mobilized and on its way to Khiam, arriving at 9:55 p.m. (Ibid) They kicked down its locked gate, stormed the bombed-out compound, and found "the near total destruction of the main building." (Ibid) They dug until the early morning hours of July 26, and managed to reach three of the four bodies of their fallen UN comrades in the rubble of the main building. Hess-von Kruedener's corpse was one of them.

"The Board finds that Major Hess-von Kruedener was not to blame for his own death. The Board was unable to determine if a specific individual was to blame for the death; the Board does however find that, as an organization, the IDF is responsible for the death of Major Hess-von Kruedener," the Canadian BOI ruled in its Nov. 1, 2006 report. The board made clear that the IDF did not co-operate with its investigation, beyond providing a "Non Paper" summary of its own investigation. (Ibid) It concluded that a 500-kilogram GPS-guided Joint Direct Attack Munition (JDAM) bomb delivered by an Israeli Air Force (IAF) aircraft caused Hess-von Kruedener's death. (Ibid)

"The results of this incident were foreseeable to the IDF," the BOI report said. (Ibid) Gen. Alain Pellegrini, the head of UN operations for Lebanon, called his Israeli liaison after the 6:29 p.m. bombings of the base, and had a heated exchange. (Day) As the BOI report stated: "More specifically, the effects of the direct impacts registered at $1829 \mathrm{hrs}$ were communicated to the IDF liaison network with clear and forceful intent and at several levels including the Force Commander stating, 'you are killing my people'." (Ibid) 
The board concluded that Hess-von Kruedener's death was "tragic and preventable." Its last word was this: "Ultimately, Major Hess-von Kruedener, along with his three colleagues, lost his life in the service of peace." (Ibid)

On July 26, 2006, one day after the fatal bombing, Prime Minister Stephen Harper raised questions about why Hess-von Kruedener and his comrades had remained at their post. He also reaffirmed Israel's right to defend itself against the Hezbollah militants inside Lebanon.

"We want to find out why this United Nations post was attacked and also why it remained manned, during what is, more or less, a war, during obvious danger to these particular individuals," Harper said. (Blanchfield "wife believes") The prime minister called the bombing a "terrible tragedy," and defended Israel's military campaign: "But that doesn't change the right of a country to defend itself against terrorists and violent attacks.” (Bailey)

Harper's comments put him at odds with UN Secretary General Kofi Annan, who blamed Israel for targeting the base. His spokeswoman, responding to Harper's remarks, said the dead peacekeepers were "posted in a well marked area and the United Nations had assurances and reassurances that they would not come under attack." (Blanchfield "wife believes")

The backlash among the Canadian military community was swift. Within days, a retired Canadian general distributed his own press release, blasting Harper. "It is shameful that Canadian politicians imply to belligerents the world over that the laws of war protecting civilians, signed conventions agreeing to accept and protect unarmed UN observers, and the lives of Canadian soldiers are irrelevant if they get in the way of their 
immediate tactical objective," said retired Major General Terry Liston, a UN peacekeeping veteran of the Congo, a mission that earned him the Order of the British Empire. (Canada NewsWire 2006) Within days of the bombing, Israeli Prime Minister Ehud Olmert telephoned Harper to express his "deep regret" and to apologize to all Canadians. (Greenaway et al. 2006)

In the weeks to come, as Hess-von Kruedener's body returned to Canada for his emotional funeral, Harper would temper his remarks, and heap the sort of praise on the deceased paratrooper that he would offer to the many, many more Canadian military personnel who would die in the coming years, mainly in Afghanistan. It would be another two years before the report into Hess-von Kruedener's death was released by the military in 2008. It was initially posted on the Defence Department's website, and then, sometime in 2009, it was gone. (Pugliese) It disappeared from the Internet, spurring accusations that the Harper government was placating its Israeli friends once more by preventing public access to the document. Hess-von Kruedener's widow, Cynthia, told the Ottawa Citizen in December 2012: "It's embarrassing to the Israelis and, as we know, Prime Minister Harper has given his unconditional support to the Israelis." (Ibid)

Hess-von Kruedener's story faded from the public consciousness after 2006. But the Harper government's staunch alliance and friendship towards Israel has grown stronger and deeper during those nine years. Canada has always been a supporter of Israel, but the Harper government has become a louder, much more unwavering friend of the Jewish state. In doing so, Harper has taken direct aim at the United Nations for fostering anti-Israeli sentiment. (CBC 2014) The UN has become a major political battleground for the Conservatives' fierce, unapologetic defence of Israel, a stance that 
has often left Canada among a small minority of nations. At the same time, the Conservative government has also maintained hundreds of million of dollars in aid spending to the Palestinian Authority, while it has worked successfully behind the scenes to help Israel build a much closer working relationship with the UN.

In Canada, the Harper government's Middle East policy has sparked a bitter political cleavage, one nearly as vast as the divide that currently separates the Israelis and the Palestinians. On one side, you have Canada's last ambassador to the United Nations Security Council, Paul Heinbecker, who said Canada's Middle East policy under the Harper government has simply become "mindless." Heinbecker, one of the most outspoken critics of the Harper government's foreign policy, served as Canada's ambassador to the UN until 2003, three years after the country's final stint on the Security Council ended. Unlike some other retired diplomats, who have joined Liberal Leader Justin Trudeau's foreign policy advisory team, Heinbecker has not thrown his hat into the political ring. He maintains he is not political, citing the fact he's been a nonpartisan political adviser to Pierre Trudeau and Brian Mulroney. He said Harper's initial reaction to the $\mathrm{UN}$ bunker bombing was simply unacceptable.

Heinbecker cited Harper's initial support of Israel immediately following the Hess-von Kruedener tragedy as one of many examples of a Middle East policy that has swung completely out of balance. "The first thing it says is it's a foreign policy totally without principle — one standard for our friends, one standard for others," he told me at his Ottawa home. "It also says - I can tell you that senior officials in the UN were furious with us - that we seemed to blame the UN for this thing." 
Heinbecker said Canada never had a completely neutral foreign policy that treated the Israelis and Palestinians equally. "We used to have fair-minded positions — not balanced. Fair-minded means Palestinians exist too, they have rights, too, and they are owed a solution to this situation as much as the Israelis are," he said. "We have (now) taken the view that the Israelis are right and the Palestinians are wrong, on everything, all the time."

On the other side are people like Shimon Fogel, the chief executive of the Centre for Israel and Jewish Affairs, Canada's largest Jewish-Israeli advocacy group. Fogel said that "the Paul Heinbeckers and the others who moan and groan about Canada having marginalized itself" have got it wrong. "Canada has consistently been a strong supporter of Israel over the years. This government first demonstrated some differences, more on style and rhetoric, than substance," Fogel told me. "It didn't use the kind of conventional language to gloss over its positions in ways that would seem more nuanced."

That has meant loudly defending Israel when it is under attack in the UN, said Fogel. "That frustration has led to a diminished regard for the UN and it agencies here in Canada," he said. "It evolved into a more clarified stand and tried to distinguish, as (John) Baird tried to distinguish, the black hats and the white hats."

Former foreign affairs minister John Baird vividly illustrated the projected moral certainty of his government's new Middle East policy during his so-called "blacks hats . . . white hats" speech to the American Jewish Congress' 2014 convention in Washington. (Panetta "middle path") To an appreciative audience of about 1,000, he recalled being a young staffer in the offices of the former Progressive Conservative governments of Brian Mulroney and Kim Campbell in the 1990s. The minister recalled sitting in a briefing on 
the subject of attacks on Israel. A federal public servant was saying how it was hard to tell the good guys from the bad guys in the Middle East — or "the white hats from the black hats." (Ibid) Baird recalled sitting there silently, scribbling on his notepad. He made two columns - labeled "white hat" and "black hat." Under white hat, he wrote the words, "Israel" and "liberal democracy" and "our best friend." (Ibid) Under black hat, he wrote "Hezbollah," "international terrorism" and "our worst enemy." (Ibid) Baird brought the Washington crowd to a round of applause when he announced his conclusion: “Twenty years later, we don't have briefings like that anymore ... There is no room for moral relativism." (Ibid) The minister declared: "The days are gone when Canada's foreign policy was defined simply by taking the middle path, by testing the temperature of those around the table, and landing somewhere not too hot, not too cold," he added. "Relativism isn't leadership; it's the easy way out." (Ibid) With that, Baird publicly redefined Canada's Mideast policy, in black and white.

This new, vocal pro-Israel stance of the Harper Conservatives was a significant departure from the nuanced shades of gray that characterized the approach of successive Liberal and Progressive Conservative governments to the intractable Middle East question in the six previous decades. Canada endorsed the birth of Israel from a special position within the United Nations. It was one of the 11 countries on the UN Special Committee on Palestine (UNSCOP), which oversaw the partition of Palestine into Jewish and Arab states in 1947 after Britain's post-First World War mandate came to an end. (Brynen 74) The state of Israel was born in May 1948 with Canada's full support. McGill University political scientist and author Rex Brynen wrote that "cultural and historical factors rather than realpolitik" shaped Canada's early support for the new Jewish state. 
(Ibid) He wrote that Canada's political leaders viewed the creation of the "Holy Land" in the context of their own fresh memories of the Holocaust, coupled with their own "predominantly Christian heritage," while the "views of the majority of the indigenous Arab population in the territory counted for little." (Ibid) As a prime example of this, the historians Norman Hillmer and J.L. Granatstein described how Lester Pearson was "a minister's son raised on Bible tales of the Holy Land and sympathetic to the Jewish population.” (81) But biographer Andrew Cohen maintained that Pearson, who would begin his tenure as external affairs minister in September 1948, was not a committed Zionist. Contrary to what some suggest, Cohen wrote, Pearson wasn't predisposed to a Jewish state. "He was under more pressure from Jews than from Arabs, to be sure, but he was, as usual, a pragmatist." (101) In some ways, this was an early manifestation of the influence of domestic politics on foreign policy. As Hillmer and Granatstein noted, "The birth of Israel was an indication that ethnic groups in Canada had continuing interests abroad and that such interest could often pose difficulties for the government." (81)

Canada's Middle East policy evolved beyond simple domestic political considerations, to embrace a more nuanced understanding of the Palestinians. This evolution occurred as Israel went to war with its Arab neighbours in the decades following its creation. Canada was in the thick of it, serving its fourth term on the Security Council, when the June 1967 Six Day War broke out. Canada still remained mainly pro-Israeli as the Jewish state's powerful military crushed its Egyptian and Arab neighbours and seized the last remaining Palestinian areas — the Jordanian-held West Bank, the Egyptian-run Gaza Strip and the Golan Heights. (Brynen 74) However, some traces of Canadian sympathy for the Palestinians could be seen in a July 1967 
intervention at the UN Security Council. George Ignatieff, the Canadian ambassador, called on the Secretary General to send a special representative to the region to start a peace process based on a "fair and balanced" resolution. (UN Yearbook 1967) In November, Canada voted in favour of Security Council Resolution 242, which called for Israel's withdrawal from the occupied territories and a negotiated solution to the dispute. (Brynen 74) Sheer economic necessity nudged Canada closer to the Palestinian cause after the 1973 Arab-Israeli War because the Arab oil embargo sent fuel prices skyrocketing. "At the same time," wrote Brynen, "a number of Israeli actions — notably, illegal settlement activity in the occupied territories, as well as the annexation of east Jerusalem — eroded Canadian support for Israeli policies." (75)

After Canada started its fifth temporary Security Council term in 1977, Ambassador William Barton affirmed the importance of Resolution 242, which called for the Israeli withdrawal from the occupied territories. He said that any peace settlement "would also have to take due account of the legitimate aspirations of the Palestinians." (UN Yearbook 1977) Privately, the Canadian government had reservations about whether the Security Council was having any effect on the Middle East crisis. A message from the then External Affairs Department to a dozen and a half foreign embassies on Sept. 22, 1977 offered this sobering assessment of the powerful body on which Canada was currently serving a two-year term. "It has not/not advanced prospects for peace in Middle East," the cable read. (DEA 1977) But it also indicated Canada wasn't giving up on the Security Council just yet: "On balance, Council has done little to enhance its position as UN organ with primary responsibility for maintenance of peace and security, although we are not unhappy with its actual performance.” (Ibid) 
Canada's two-year term had expired by the time the Council, in March 1979, adopted two more key resolutions, 446 and 465, which branded Israeli settlements illegal, and a violation of the Fourth Geneva Convention that prohibits a country from transferring its own civilian population to land seized in war. Canada adopted that position and it remains the country's official foreign policy to this day, in spite of the Harper government's current reluctance to verbalize it.

When Harper finally travelled to Israel in January 2014, he steadfastly refused to restate the government's position on the Israeli settlements, leaving it to his host, Israeli Prime Minister Benjamin Netanyahu, to tell journalists that the two leaders disagreed on this point - in private. (Goodman) Harper suggested his silence was meant to cut the Israelis some slack in a tough neighbourhood. "The one lesson I think we have learned is that when somebody is a minority, particularly a small minority in the world, one goes out of one's way to embrace them, not to single them out for criticism. That's a fundamental Canadian ethic," Harper said. (Ibid)

Canada didn't begin to recognize the Palestinians as an entity until the late 1980s after their first uprising, or Intifada, of 1987, which occurred on the watch of the Mulroney Progressive Conservative government. Through most the 1980s, Brynen wrote, Canadian officials offered only "vague support for a Palestinian 'entity' or 'homeland' rather than a Palestinian state.” (77) Canada began to accept the notion of Palestinian statehood after the 1993 Oslo Accords and the March 2002 Security Council resolution that affirmed the concept of a two-state solution. (Ibid) Today, under the Harper government, that's still the stated policy — a negotiated two-state solution, in which a new Palestinian state peacefully coexists with Israel and recognizes its right to exist. 
But some see a problem with that seemingly balanced position, one that's simply not reflected by the reality on the ground in the region. "We're supposed to think these negotiations are among equals," said Heinbecker. "The Israelis are one of the most powerful military forces in the world."

In 2004, Liberal Prime Minister Paul Martin repositioned Canada more firmly on Israel's side at the United Nations. His ambassador, Allan Rock, put the UN on notice that Canada would be supporting Israel in upcoming votes on the Israeli-Palestinian question because of "long-standing concerns." (Blanchfield et al. "Liberals fight") Canada had a long tradition of simply abstaining on the approximately two-dozen resolutions that would come before the General Assembly each year criticizing Israel. (Ibid) Martin decided that Canada would stop abstaining and join the United States and a handful of other countries in voting against resolutions perceived to be anti-Israeli. (Ibid) In most of these cases, Canada and its allies lost badly, by a vote of 104-7 with 63 abstentions in one case. (Ibid) Arab and Muslim groups complained, but the CanadaIsrael Committee — an earlier incarnation of Fogel's organization — said it would be a step towards correcting the "continued and systematic abuse and isolation of Israel within international institutions." (Ibid) Martin also balanced this new pro-Israeli policy with a very vocal show of support for the Palestinians. He pledged Canada's support for a new peace process, and he called on Arab leaders to hold his government's "feet to the fire" if it didn't offer support to the Palestinians in the future. (Ibid)

Fogel said the Martin Liberals essentially prepared the ground for what the Harper Conservatives would do once in power. "The current government accelerated a process that really began with the previous Liberal government," he said. "It sort of exacerbated a 
longstanding question that successive Canadian governments had about the utility of the UN and how it was deficient, what was required in order to reform it," Fogel added. So the Harper government "started focusing its efforts on where it should be flagging the deficiencies and how to propose remedial action." The Martin government may have started a course correction, but it was Harper's that revved the country's political engines full speed towards Israel.

The newly elected Stephen Harper arrived at the United Nations General Assembly in September 2006, fresh from the controversy his "measured response" remark had ignited during the summer war in Lebanon. The prime minister used his speech to take sharp aim at an institution that had been anathema to Israel: the newly created Human Rights Council. It had replaced the troubled UN Commission on Human Rights earlier that year. "Will the new Human Rights Council become a forum where human rights are genuinely put above political maneuvering? Or will it emulate the fate of its failed predecessor organization?" Harper asked. (2006b) "But I must tell you, the early signals suggest that too little has changed, that the page has not yet been turned." (Ibid) At the time, Syria was the council's chair.

In 2008 and 2010, the Canadian Senate became seized with the controversial UN institution when its human rights committee undertook two major studies of the Human Rights Council. The Senate committee issued a pair of reports in both those years that criticized the council as being ineffective and discriminatory towards Israel. Its 2008 report said that Canada and the European Union found itself "pitted against" Islamic and Arab states, and the Non- Aligned Movement. (Senate 2008, 28) "The outcome of this 
political battle is more than evident in the fact that the human rights situation in Palestine and Occupied Arab Territories was put on the Council's permanent agenda, and that more than half of the Special Sessions have been held on issues surrounding Israeli actions," the report said. (Senate 2008, 29) NGOs in Geneva told the committee that the 'bully' factor has become a fact of life on the Council." (Ibid)

In its 2010 report, the committee said that its examination of recent UN voting patterns "revealed that the Council continues to be a proxy for larger geo-strategic conflicts, such as the Israeli-Palestinian conflict." (Senate 2010, 29) Canada's decision to vote against anti-Israel resolutions, rather than abstain, often left the country standing alone. "Canada has on a number of occasions been the sole dissenter," the committee said in 2010. (Senate 2010,30) The report noted that while the European Union has tried to build a consensus on the Council, Canada found this to be a "time-consuming challenge" that was simply not worth it. (Senate 2010,31) "Canada's position with regards to IsraeliPalestinian issues has further left it marginalized, and according to some witnesses, exacerbated the bloc politics already at play," the Senate report said. (Ibid)

The spectacle of the poorly functioning Human Rights Council was on full display in September 2013 when Cuba, Russia, Iran and Belarus - countries with poor human rights records — used the forum to pile on Canada. (Blanchfield "rejects UN") The council was conducting its Universal Periodic Review of Canada's performance on rights, measuring a wide range of issues including poverty, immigration and crime. (Ibid) Canada rejected a series of resolutions that called on it to conduct a national review of violence against aboriginal women, a hot topic inside Canada that had the Harper government under pressure domestically. Canada's ambassador to the UN in Geneva, 
Elissa Golberg, politely told the meeting that the country was proud of its human rights record, and that provincial and local governments were looking after aboriginal women's issues. (Ibid)

The Human Rights Council represented "multilateralism at its worst," as far as David Mulroney was concerned. "The argument that you've got to be there, you've got to be part of the solution, broke down," he said. "I don't know how we could participate in that and still keep our heads up high.”

Previous Liberal governments also clashed periodically with the UN Commission on Human Rights, the precursor of the Human Rights Council. In 1981, Liberal Solicitor General Robert Kaplan bristled at criticism that Canadian parole legislation breached a UN covenant and angrily said Canada was a sovereign nation and would not be bound by a committee finding (Nolan 109). In 1996, Canada ignored a finding that Ontario's funding of Roman Catholic schools was a violation of the United Nations International Covenant on Civil and Political Rights because it did not fund other faiths, such as Judaism. (Nossal et al. 39)

Jason Kenney, one of Harper's most versatile and valuable cabinet ministers, was a frequent, outspoken critic of the UN Human Rights Council. He accused it of passing "dozens" of resolutions against Israel, "but virtually none on brutal dictatorships like Iran and Syria." (Blanchfield "Baird blasts") In May 2012, Kenney gave a public tongue lashing to the UN Special Rapporteur on the Right to Food, who was making an 11-day trip to Canada to research a report. Oliver De Schutter was making the rounds in an effort to determine whether Canada was living up to its responsibilities to make sure poor people got access to nutritious food. "We have in this country more than 800,000 
households who are considered food insecure," De Schutter said. "This situation is of great concern to me." (Payton) Kenney, then the immigration minister, said De Schutter was wasting his time in Canada. "It would be our hope that the contributions we make to the United Nations are used to help starving people in developing countries, not to give lectures to wealthy and developed countries like Canada. And I think this is a discredit to the United Nations," said Kenney. (Ibid) Kenney has been equally outspoken in defending Israel at the UN, most notably in November 2010 when he announced that Canada would once again boycott its anti-racism convention in South Africa, known as the Durban III conference, calling the widely-criticized gathering an anti-Israeli "hatefest." (Galloway)

As forceful as Kenney could be, it was John Baird who took the lead in defending Israel against broad UN criticism after becoming foreign affairs minister in 2011. In Baird's full-throated support of Israel, the prime minister had found a like-minded, kindred spirit to articulate his own deeply held views. During the keynote address to Jewish Canada's biggest gala evening in November 2012, Baird explained why he felt so strongly about how Israel, describing how his "grandfather left Canada to fight the Nazis" 70 years earlier. "I'm deeply influenced by his contribution to combating an evil, which sought to exterminate the Jewish people ... that moment in history when the Devil almost drove a stake through the heart of humanity," Baird told his audience at the annual Negev dinner. (Baird 2012) "The heavy spirit, the knotted stomach, and the paralysis of shock I felt as I learned details of the horrors of the Nazi era have been ingrained in my soul; they shook me to my core and have become part of my DNA." (Ibid) 
When he travelled to Israel later that year, Baird brought along an ultra-orthodox Chabad rabbi from Ottawa's Hasidic community. "I have a confession to make," Baird would say on several stops on this trip, "I'm not Jewish ... But I do have a rabbi, and he's accompanying me on this trip." (Martin 2012)

Baird proudly displayed his pro-Israeli viewpoint when he made his international debut at the United Nations. Baird threw down the gauntlet during his speech at the General Assembly in September 2011, when he declared that Canada would no longer go along, "to get along." He criticized the Human Rights Council and equated Israel's critics with the appeasers of Nazi Germany before the Holocaust. (Baird 2011) Baird said Canada was now "standing for what is principled and just, regardless of whether it is popular, or convenient, or expedient." (Ibid)

Baird's speechwriters also wanted him to say a few positive things about the Palestinians, but the minister decided to leave those suggestions on the cutting room floor. "Canada is a leading supporter of the Palestinian people, having committed $\$ 300$ million over five years to assist the Palestinian Authority to build capacity in the key areas of justice sector reform, security, and sustainable economic growth, as well as providing humanitarian assistance to Palestinians in West Bank and Gaza, including refugees," said a paragraph from an early draft of Baird's speech that never made it into the final version, drafts of which I obtained under the Access to Information Act. (Blanchfield "cut pro-Palestinian") Another passage that Baird rejected, said: "Our support for the West Bank and Gaza demonstrates Canada's ongoing commitment to assist Palestinians in building the foundations of a viable, independent, democratic and peaceful Palestinian state living side by side in peace and security with Israel.” (Ibid) 
Yves Fortier, Canada's UN ambassador when it was on the Security Council in 1989-90 during the Mulroney era, told me that, "you don't have to be a rocket scientist" to see how the final version of Baird's 2011 speech, as delivered, resonated "very negatively" throughout the UN. "It's unlikely to lead to a renewed love relationship between Canada and the other member countries of the United Nations. It's as simple as that."

Stephen Lewis, who preceded Fortier to the UN as Mulroney's ambassador, said Harper's close friendship with Netanyahu "poisons the atmosphere" against Canada at the UN "because Netanyahu is such an unprincipled scoundrel. So for Harper and Netanyahu to be seen as Tweedledum and Tweedledee is hard for people to take seriously." Lewis and Netanyahu got to know each other in New York when they both served together as their countries respective ambassadors. They dined together with their wives on more than one occasion.

"We were ideologically as far apart as we could be but he was a very bright, interesting raconteur," Lewis recalled. "He and I often talked because we were, interestingly enough, the only two Jewish ambassadors prepared to admit that they were Jewish - and wore it on our sleeves. There were a number of other Jewish ambassadors who begged us not to reveal their ethnicity. It's amazing. There was so much antiSemitism in the '80s. It was very unpleasant." In the Mulroney era, in the Chrétien years that followed, Canada displayed a nuanced position at the UN, especially towards the Middle East, he said.

For Heinbecker, Baird's 2011 UN speech was “a mixture of sour grapes and neocon ideology." He said its loss of the 2010 Security Council election made the UN "more 
of a problem" than it had been previously for the Conservatives. "We sit on the sidelines in a kind of truculent sourness making judgments about things we scarcely understand."

Baird continued criticism of the UN in defence of Israel. In October 2012, he called for the firing of Richard Falk, the UN's special rapporteur on human rights in the Palestinian territories. Falk called for a boycott of companies doing business with Israeli settlements in the West Bank and East Jerusalem. (Blanchfield "Baird blasts") Baird said Falk's comments were "offensive" and "outrageous" and concluded, "they've got to be condemned." (Ibid)

A month later, on Nov. 29, 2012, Baird made a special trip back to the UN General Assembly, this time to give a speech opposing the Palestinian bid for nonmember observer status at the UN. The Palestinians won by a huge margin that day. Canada, Israel, the United States and six small countries voted against the Palestinians, and Baird was the only foreign minister to make a speech in support of that opposition. The U.S. chose not to speak publicly on the matter, trusting that its vote, coupled with its clearly stated and long-held policy of supporting Israel, would speak for itself in the General Assembly. Baird fully expected the Palestinians to succeed, but he said Canada had to "stand up for what we believe is right." (Blanchfield "Canada opposes") Baird said he was "tremendously disappointed" with the Palestinian bid because he considered it an unproductive way to negotiate peace with Israel. He said it would affect Canada's relationship with the Palestinians, and added: "This government makes no apologies for standing with the Jewish state.” (Ibid)

Two countries that Baird had identified as top foreign policy priorities and that he had been working hard to build bridges with - Indonesia and Turkey — made no 
apologies for standing up for the rights of the Palestinians. Baird's speech was sandwiched between meetings with Indonesia's Marty Natalegawa, who visited Ottawa the previous August, and Turkey's Ahmet Davutoglu, who paid a visit one month later in September. Natalegawa pointed out that Indonesia, as the world's most populous Muslim country, was the co-sponsor of the Palestinian resolution. (Blanchfield "Canada recalls") "The time has come for the international community to set things right. No longer can the world turn a blind eye to the long sufferings of the Palestinian people, the denial of the basic human rights and their fundamental freedoms, the obstruction of their rights to selfdetermination and to independence," Natalegawa said, noting the "enormous barriers erected by the occupying power" in the Palestinian territories. (Ibid) For his part, Davutoglu said Gaza had become a place where "thousands of people live through an inhumane blockade in an open prison.” (Ibid) Flatly contradicting Baird, Davutoglu said the UN recognition of the Palestinians would move the peace process forward, not hinder it. (Ibid) Four months later, Baird elaborated on his efforts to block the Palestinian statehood bid in a speech to the powerful U.S. lobby group, the American Israel Public Affairs Committee, during its annual meeting in Washington, D.C. (Blanchfield "Palestinians could face") Baird addressed his government's critics once again, repeating that Canada would not "go along to get along with some moral relativist crowd at the United Nations or elsewhere." (Ibid) Enthusiastic applause followed. Baird kept it going, saying: "Well, listen, parents around the world tell their kids that's wrong . . . and it's certainly wrong in the halls of the United Nations." (Ibid)

In April 2013, Baird returned to Israel — and sparked another furor for which he made no apologies — when he decided to have a cup of coffee in East Jerusalem with 
Israel's Justice Minister Tzipi Livni, who also happened to be her government's chief negotiator with the Palestinians. Baird had decided to hold a meeting with an Israel official in an area where other western leaders simply do not; the Palestinians and the United Nations consider East Jerusalem to be occupied land. Canada's stated policy on the Foreign Affairs Department website says: "Canada considers the status of Jerusalem can be resolved only as part of a general settlement of the Palestinian-Israeli dispute. Canada does not recognize Israel's unilateral annexation of East Jerusalem." (DFATD 2013)

As the criticism - not to mention the surprise — mounted over the choice of location for Baird's coffee with Livni, the response from the minister and his staff was glib. To them, the sensitivities surrounding Jerusalem and international law — not to mention Canada's own policy — didn't seem to matter. Baird said he remained supportive of the Israelis and Palestinians returning to the negotiating table, as he brushed aside questions about the location for that cup of coffee as simply "irrelevant." (Brewster)

"I'm just not interested in getting into the semantic argument about whether you have a meeting with one person on one side of the street, it's OK, and you have a meeting on the other side of street, and it's not," Baird said. (Ibid) "We're focused on trying to have an impact on the difficult and serious challenges, that being security for Israelis, an end to the conflict, and the legitimate aspirations for a state from those in the Palestinian side." (Ibid) Baird's spokesman, Rick Roth, followed up in an email, saying: "As guests, we were pleased to meet our hosts where it was most convenient for them." (The Canadian Press 2013) 
Saeb Erekat, the chief Palestinian negotiator, saw it differently. He sent Baird a protest letter. "Your recent meeting with Israeli officials in East Jerusalem has the effect of attempting to legitimize the illegal situation on the ground and may be deemed as aiding, abetting or otherwise assisting illegal Israeli policies," he wrote. (Ibid) "As such, Canada's actions are tantamount to complicity in ongoing Israeli violations of the international laws of war." (Ibid)

Some seasoned ex-Canadian diplomats were left scratching their heads. "Our policy on Israel was absolute blindness," Heinbecker told me. "Partly out of religious fervor, partly out of political interest, none of it out of principle, none of it out of respecting international law."

So much of the Conservative government's foreign policy has been driven by domestic political calculations, but not the Middle East. That's different. Ideology, not domestic political considerations, is the prime driver. This direction is coming from Prime Minister Stephen Harper himself, and it is rooted in his most formative experiences.

Stephen Harper's affection for Israel begins and ends with his father. As author John Ibbitson explains in his forthcoming biography of the prime minister, Harper's loyalty to Israel springs from his deep reverence for Joe Harper. (Ibbitson) "Harper's devotion to his father is deep and lasting," Ibbitson wrote. "But nothing that Joe Harper transmitted to his son could match the impact of his views on Israel." (Ibid) The Polish immigrant Harvey Gellman, a pioneer in Canadian computing, befriended the elder Harper while they worked at Imperial Oil. (Ibid) Gellman had come to Canada as a child 
survivor of the Holocaust, during which he lost many relatives. (Ibid) Ibbitson wrote that Gellman told Harper many stories about this family, and they "left a lasting mark on Joe, who had always hated intolerance, convincing him that the Jews had a right to their own homeland." (Ibid) Joe Harper passed that "fervent conviction" on to his three sons, the eldest being the future prime minister of Canada. (Ibid) "One of them acted on it," Ibbitson wrote. (Ibid)

Shimon Fogel said he knows Harper well and has no doubt that his stance on Israel is guided by an ideological moral certainty — one that still managed to generate some very real domestic political benefits. "I think that the electoral benefits or the partisan benefits have been sort of collateral bonuses for the government," said Fogel. Any political party is going to want to score points with specific segments of Canadian voters, he said, but with the Harper government "it certainly wasn't the case that the government said, 'the Jewish communities are a ripe pool of support from which we can benefit, so let's change policies so we can attract their support.' I think it was exactly the opposite." As a result, Fogel said, the Conservatives have managed to unseat the Liberals as the party of choice for Jewish voters. That's translated into Conservative victories in the Toronto area for Finance Minister Joe Oliver, former environment minister Peter Kent and MP Mark Adler. These ridings, said Fogel, "typically would have gone Liberal."

Adler stole headlines away from his prime minister during his January 2014 visit to Israel when he was caught on camera trying to bust into Harper's photo-op at the Western Wall in the Old City of Jerusalem. Adler was captured on video by a reporter travelling with Harper trying to coax Jeremy Hunt, of the prime minster's aides, into 
letting him get into the shot. (Huffington Post "Adler") "Jeremy. Jeremy! Can I get in?" Adler pleaded. "It's the re-election! This is the million-dollar shot." (Ibid)

Harper has swayed Jewish voters because, said Fogel, they have judged his views on Israel as sincere. Fogel pointed to Harper's 2014 speech to the Israeli Knesset, where he gave a nuanced analysis of how political opposition to Israel can sometimes cross a line and become anti-Semitic. "Now I understand, in the world of diplomacy, with one, solitary, Jewish state and scores of others, it is all too easy 'to go along to get along' and single out Israel," Harper told Israel's parliament. (CBC 2014) "But such 'going along to get along,' is not a balanced approach, nor a sophisticated one. It is, quite simply, weak and wrong." (Ibid) Harper said criticism of Israeli policy is not necessarily anti-Semitic. "But what else can we call criticism that selectively condemns only the Jewish state and effectively denies its right to defend itself, while systematically ignoring — or excusing — the violence and oppression all around it?" the prime minister rhetorically asked. "What else can we call it when Israel is routinely targeted at the United Nations?" (Ibid) Harper's speech was a reminder that sometimes criticism of Israel is not simply a policy disagreement, Fogel said. "Often it portrays Israel as some kind of unique evil that, really, it just becomes the proxy for the Jew," he said. "And in those cases, it's hard to explain it as anything other than anti-Semitism."

David Mulroney has seen evidence of a clear link between the new modern Conservatism that Harper embodies and Israel. "If you've ever been in the office of a Conservative staffer in Ottawa, one of these young people who was in the young Conservatives in college, they generally have three kinds of symbols in their office: they have something to do with Ronald Reagan, they have a Margaret Thatcher picture and 
they have an Israeli flag," he told me. "Those are the touchstones of modern grassroots Conservatism - one of the main touchstones of modern conservatism as opposed to progressive conservatism as we know it."

For all of Harper's criticism of the UN over its treatment of Israel, his government has quietly brought the Jewish state closer to the organization than any previous Canadian prime minister. In his Knesset speech, Harper welcomed the fact that Israel had joined the Western European and Others Group of the United Nations. (CBC 2014) The UN divides member countries into five regional groups, which co-ordinate which countries can sit on committees and run for the Security Council. Arab states rejected Israel's membership in the Asian group, its natural geographic affinity, and that has prevented it from participating in a host of UN bodies, including the Human Rights Council and the Security Council. (Jerusalem Post) "Canada believes that Israel should be able to exercise its full rights as a $\mathrm{UN}$ member-state and to enjoy the full measure of its sovereignty," Harper said in his Knesset speech. (CBC 2014)

Israel's ambassador to Canada Rafael Barak told me that Canada helped persuade other countries in the western group to accept Israel into its ranks. The veteran diplomat was able to explain the value for his country of gaining entry into an international club that both Israel and the current Canadian government view with such deep-seated antagonism: it would enable the Jewish state to defend itself at the UN. (Blanchfield "Israel thanks") “We were, in a way, in limbo," Barak told me. "We don’t want to be a one-issue country, dealing only with our political constraints." (Ibid) Barak said gaining fuller access to UN would also allow Israel to play a more constructive role on the world 
stage, including allowing it to pursue its own temporary, two-year term on the Security Council, something Israel had never done. (Ibid)

"From Israel's perspective, they were very grateful because it gives them the opportunity to participate in things they wouldn't otherwise be able to do," added Fogel. Israel has been able to secure leadership positions in some UN agencies, including the World Health Organization, he added. "To the extent that Israel is able to participate more fully in the UN operations, it helps normalize Israel in the eyes of countries that have not previously had anything to do with Israel, no exposure to it, and no ability to accurately evaluate Israel as a nation state and a member of the international community."

Months after Harper left Israel, Canada found itself once again defending the Jewish state against the Human Rights Council. In July 2014, Baird expressed frustration and deep disappointment over the Council's decision to launch an international commission of inquiry to investigate possible violations of international law by Israel in its summer war in Gaza. "Canada is frustrated and deeply disappointed that the UNHCR decided to completely ignore the abhorrent terrorist acts of Hamas," Baird said, pointing out that the militant organization had been indiscriminately firing rockets into Israeli neighbourhoods where millions of innocent civilians lived. (The Canadian Press 2014) Baird said the failure to condemn the "reprehensible actions of Hamas has only emboldened its brutality and encouraged these terrorists to continue their inexcusable actions." (Ibid) The 50-day summer war, however, killed 2,100 Palestinians — most of them civilians — and 72 Israelis, most of them military personnel. (Rasheed and Estrin) 
Baird's last foreign trip before he suddenly quit politics in February 2015 included a five-day tour of the Middle East in mid-January. He returned to Jerusalem and Tel Aviv, and also made one last memorable stop in Ramallah, the Palestinians' West Bank capital. Baird said the Palestinians had made a "huge mistake" and crossed a "red line" by joining the International Criminal Court and pushing for a war crimes investigation of Israel in the Gaza war of the previous summer. (Blanchfield "huge mistake") Baird said he communicated that message "in no uncertain terms" during his meeting with the Palestinian leadership in Ramallah. (Ibid) When Baird emerged from their meeting in Ramallah, his motorcade was pelted with eggs and shoes by an angry group of demonstrators.

Today, the government's current Middle East policy leaves a bitter divide in Canada. Heinbecker, Canada's former UN ambassador, said he was not the least bit surprised by the scene of Baird's motorcade being deluged with eggs and footwear. The Palestinians "go through decades of fruitless negotiations and they're supposed to behave as if everything is in fine," he said.

"Baird was lucky it wasn't hand grenades they were throwing."

The Palestinians don't dislike Canada, Fogel said, brushing off the Baird protest as internal political posturing. He recalled how former Liberal foreign affairs minister John Manley had been burned in effigy by the Palestinians a decade earlier. Fogel said the Palestinians appreciate the Canadian government's generous annual development support of $\$ 300$ million. "On the contrary," he said, rebuffing the notion that Canada has lost respect in the region, "it's been able to demonstrate over the last nine years both an ability to put its money where its mouth is, as it has with the Palestinians." 
That may have been the case, but behind the scenes recently, Canada has also been forcefully opposing Palestinian statehood ambitions at the $\mathrm{UN}$ in concert with Israel. In January 2015, Canada unequivocally opposed 15 separate Palestinian attempts to join various UN treaties, conventions and protocols. (Blanchfield "Palestinian attempts") Canada objected to the Palestinians acceding to the Rome Statute that created the International Criminal Court, and a host of other agreements, including the Convention on Biodiversity, the Basel Convention on the Control of Transboundary Movements of Hazardous Wastes and their Disposal, the UN Law of the Sea, a convention against transnational organized crime, a protocol on biosafety and biological diversity and the convention on women's rights. (Ibid) Repeatedly, Canada's objections said, “'Palestine' does not meet the criteria of a state under international law and is not recognized by Canada as a state," adding that Canada considers any declarations "made by the 'State of Palestine' to be without any legal validity or effect." In its reply, "The State of Palestine" said repeatedly that it "regrets the position of Canada and wishes to recall" the resolution of Nov. 29, 2012, that granted it "non-observer state status in the United Nations." (Ibid)

Said Hamad, the chief representative of the Palestinian delegation to Canada, sent me an emailed response when I asked him to comment on this latest development. I've met Hamad briefly on a handful of occasions during his tenure in Ottawa in recent years, and he is every inch the diplomat. During that time, he's refrained from making anything resembling a provocative comment, on or off the record. This time, he dropped the gloves. 
"It pains the Palestinians to know that Canada is trying to exclude us from our rightful place in the family of nations. It is awkward to see a great country like Canada relegated to the role of cheerleader for Israeli extremists at the UN," Hamad told me in his emailed response. (Ibid) "When future Canadians look back at Canada's positions during this time they will be appalled that their country was so boldly opposed to justice and so far on the wrong side of history," he added. "We invite Canada to pursue a position of its own - rather than parrot policies developed by the Likud Party and its ultranationalist allies — on the matter of Palestinian freedom.” (Ibid)

Yves Fortier, the former Canadian UN ambassador from the Mulroney era, has avoided weighing in publicly on Canadian foreign policy since his stint in diplomacy ended two decades ago. Since then, he has thrived as a respected international lawyer who specializes in mediation. He has a private practice that regularly takes him to London and Washington, where he earns a premium to find common ground among opposing sides - helping them get along and find a way to settle their grievances. Fortier selects his words carefully, and speaks in the measured tones of a judge.

"My statement is not a political one," Fortier told me.

Canada, he said, will remain outside the mainstream of the United Nations unless Stephen Harper changes his mind about the Middle East. "Is he seen by other countries as an aficionado, as a supporter of the United Nations? Today, I would have to say, no," Fortier said.

"We've lost our credibility as a fair-minded participant in the continuing Middle East dilemma. We're seen as: Israel can do no wrong, and the Palestinians can do no good. That doesn't put us on the side of any Arab country today." 


\section{Conclusion}

The spectre of the United Nations, despite the acknowledged impotence of its Security Council, hung over the House of Commons debates of March 2015 as the Conservatives, New Democrats and Liberals sparred over the Canadian Forces upcoming mandate to take part in a one-year bombing mission in Syria being led by the United States. The intended aim was to finally crush the onslaught of the ISIL, the Islamic State of Iraq and the Levant, across the region. Canada had already been taking part in bombing inside northern Iraq, but now it was planning to join a U.S.-led mission along with five Arab countries - Saudi Arabia, Jordan, Qatar, the United Arab Emirates and Bahrain - to take the combat mission deeper into Syria. Like the rest of the world and the Security Council it was no longer a part of - Canada had done nothing to actively stop the genocide that had been unfolding in Syria for the previous four years. The council was deadlocked by the veto of its permanent member, Russia, an ally of Syria. The civilian death toll stood at 220,000, and more than 11 million Syrians had been forced to flee their homes, either as refugees to neighbouring countries, or as internally displaced people within their country's borders. The carnage started in March 2011 when a popular uprising, inspired by the Arab Spring, was brutally crushed by Syrian President Bashar Assad, who turned his armed forces' weaponry on his own people. Armed militant groups formed to battle the government, and each other. These included wellintentioned democrats, who were eventually crushed, offshoots of al-Qaida, and eventually ISIL, which seized large tracts of land inside Syria and northern Iraq, enslaving the local populations, killing non-Muslims, and forcing all to adhere to their medieval interpretation of Islam under the umbrella of their new "Caliphate." It is 
extremely serious stuff, the security challenge for our time — and something the United Nations has not been able to stop. Though Canada's parliamentarians had paid lip service to the tragedy inherent in the world's tragic and historic failure to protect Syria's innocent civilians, the level of debate on the issue among this country's three political parties was centered on which one could use the tragic events to the best political advantage with the next federal election on the horizon, six months away.

The bitter exchange between NDP Leader Thomas Mulcair, the leader of the Official Opposition, and Prime Minster Stephen Harper during Question Period on March 25, 2015 was the clearest illustration of how petty, partisan domestic political considerations had infected foreign policy. Mulcair wanted to know something perfectly reasonable: how, under international law, Canada was justifying the military action within another country's borders. Syria hadn't invited the other countries to bomb ISIL on its territory and there was no United Nations Security Council Resolution authorizing the use of force. Mulcair wanted to know if Canada had notified the United Nations Secretary General, as the American ambassador to the UN had done in September 2014, that it was invoking Article 51 of the UN Charter, the self-defence provision, as the legal basis for its decision to bomb inside Syria. (Blues March 25)

Harper repeatedly blew off the question as a nuisance, and refused to answer. "The government is pursuing this action on exactly the same legal basis as its allies," the prime minister told the House of Commons, without offering any further explanation. (Ibid) "I am not sure what point the leader of the NDP is ultimately making. If he is suggesting that there is any significant legal risk of lawyers from ISIL taking the 
Government of Canada to court and winning, the Government of Canada's view is that the chances of that are negligible." (Ibid)

Mulcair was livid. "Mr. Speaker, extraordinary. Living in Canada where that sort of idiocy passes for argument in the House of Parliament ...” (Ibid)

Andrew Scheer, the Speaker of the House, admonished Mulcair over his choice of language and the NDP leader moved on to another topic of questioning. (Ibid)

But Harper wouldn't let it go. Twice, he brought the argument back to Mulcair's point, even though the topic had shifted. Harper wanted the last word at all costs, but that did not include answering the question. "I would be remiss if I did not return to the previous exchange," Harper said. "While I will obviously not repeat the terminology used by the leader of the NDP, if his idea of protecting Canada's national interest is that we do not do everything in our power, legally, militarily and in terms of co-operation with allies, to defend the interest of this country against the terrorist caliphate, he and I obviously have very different ideas of what are the national interests of this country." (Ibid)

Mulcair responded by asking another question about the imprisoned blogger Raif Badawi, who faced a severe flogging sentence in Saudi Arabia, but not before taking his own shot back. "The Prime Minister of Canada thinks he is above international law also; he is not and Canada is not. This is all we have." (Ibid)

Again, in what was a rare piece of Parliamentary debate, Harper returned to the original fight. But he still didn't answer the question, though he vaguely invoked the UN and lunged for the moral high ground, suggesting that political parties in other countries had managed to leave their partisan differences out of the war debate: 
Once again, I do want to return to the previous exchange. If the leader of the NDP is suggesting for a moment that there is any case of the international legal community that stands behind ISIL, he is not only wrong, but the international community has united in opposition to this group. Five dozen members of the United Nations have united to confront this international terrorist organization. Canada is working with them. Canada is working, not only with people from our own political family, but liberals and social democrats across the world in taking a strong stand to stay this ruthlessness. (Ibid)

Once again, as Canada was poised to plunge deeper into a new Middle East war, the tensions between our traditional adherence to multilateralism and the tendency for the Harper Conservatives to join coalitions outside the UN framework was on full display. So, too, was the bitter domestic partisan politics that reared its head in the 2003 Iraq debate. This time it was the NDP that was in the fray with Mulcair and the party's foreign affairs critic Paul Dewar tangling with the government.

"The new motion extends Canadian air strikes into Syria without a UN or NATO mandate and without the permission of the Syrian government ... First, the action may well be illegal. Second, the government has done nothing to show that it takes international law seriously at all," said Dewar. (Blues March 26)

"After the Prime Minister belittled and joked about international law yesterday afternoon, the government was forced to move quickly to cover up the fact that it had not sent notice of its intention to the UN Security Council, as is required in cases of self- 
defence, and the legal case that bombing in Syria constitutes any form of self-defence has not been made.” (Ibid)

As the bitter exchange between Mulcair and Harper had unfolded the day before, the simple fact remained that the Canadian government had not yet informed the United Nations Security Council, in writing as required, of its intention to take part in the bombing inside Syria. (Wherry) The United States had done just that, on Sept. 23, 2014, when its UN ambassador, Samantha Power, stated in a letter the UN Secretary General Ban Ki-moon that her country had initiated "necessary and proportionate military actions" in Syria to combat the threat posed by ISIL and an al-Qaida affiliate. (Vox) Power's letter invoked Article 51 of the UN Charter, which affirms the right of all countries to an "inherent right of individual or collective self-defence" — as long as the UN was notified in writing. (Ibid) Shortly after the Mulcair-Harper scuffle, a junior minister in the government, Bernard Trottier, the parliamentary secretary to the foreign affairs minister, told the $\mathrm{CBC}$ that Canada wouldn't be sending the UN any such letter, nor was one required. (Wherry) Two and a half hours later, Trottier informed the public — in a Twitter message — that the government would, in fact, be notifying the UN "on same basis as Obama administration ... as req'd by Art. 51." (Ibid) In all, the incident embodied the government's flagrant disregard for international norms in the face of a bitter partisan struggle.

The NDP didn't look a whole lot better. Mulcair boldly declared that his party would bring home the troops after it formed a government — a repeat of his party's tired, unthinking strategy on the Afghanistan mission. (Blues March 24) Mulcair was playing to his core constituency: the left-leaning, anti-war voters who form a key part of the 
NDP's voting base but represent a viewpoint determined to ignore the difficult but unavoidable realpolitik of international relations in the modern world.

Meanwhile, the Liberals under Justin Trudeau were spinning their wheels, evoking their party's foreign policy in the most vague of terms, and voicing no concrete solutions. Trudeau hinted during the debate that as the election approached he might have more firm ideas. "These calamities are in urgent need of a constructed, coordinated international effort, both through the United Nations and beyond it. It is the kind of effort that ought to be Canada's calling card in the global community." Trudeau's argument for not supporting a combat mission, and instead advocating for more of a humanitarian response was, on the surface, not unreasonable. He had argued the government had not been forthcoming about the true role of its special forces trainers in Iraq after the revelations that they had exchanged gunfire with ISIL troops.

But that was all clouded by the crude, juvenile joke he had made during a thinktank question-and-answer session in October 2014 about the initial deployment of Canadian fighter jets to Iraq in the first stages of the ISIL mission: "Why aren't we talking more about the kind of humanitarian aid that Canada can and must be engaged in, rather than trying to whip out our CF-18s and show them how big they are?" (Huffington Post "Trudeau's Whip Out")

Now more than ever before, it would seem that there is a paucity of progressive, constructive ideas on Canada's political landscape about the nation's place in the wider world, and no mature, rationale discussion on how to change or improve the cracked system of global governance. On Syria, the UN system - particularly the Security Council — has looked as impotent and ineffective as it ever has. Meanwhile, Canada's 
current politicians are dishonouring the legacy of their post-war forefathers, replacing their cry of "never again" with "vote for me."

How did we get here? In December 2009, on the $100^{\text {th }}$ anniversary of the creation of Canada's foreign affairs department (external affairs as it was originally known), a group of scholars and diplomats gathered at Dalhousie University in Halifax to grapple with where our country was going in the world. As they looked back over the previous century, there was far less interest in the first 97 years of the department's history than in what had transpired in the previous three, after Stephen Harper's government was elected. “The Prime Minister's deep reservations about the United Nations, his aggressive approach to climate change negotiations, and his ease within Washington-led coalitions of the willing promised a diplomacy that was more focused on a limited number of specific Canadian goals and objectives than ever before," stated David Black, the director of the Centre for Foreign Policy Studies at Dalhousie University, and Greg Donaghy, the head of the Historical Section at the Foreign Affairs Department, in their summary of the one day-conference. (Black and Donaghy) “This does not mean that Mr. Harper ever intended to abandon completely Canada's strong postwar attachment to working multilaterally. However, it does seem clear that his government is likely to think long and hard about its multilateral commitments, making them more sparingly and selectively." (Ibid)

Given how Harper has behaved towards the United Nations in the six years since then, the Dalhousie scholars were clearly on to something in 2009. Harper isn't the first prime minister to be skeptical of the UN, but he has taken a much harder line towards the 
organization than any other leader. That includes Canada's first UN-skeptic prime minister, Pierre Trudeau.

Stephen Harper has changed how Canada views the world, and this by extension has shaped how the world has come to view Canada. And he has altered the Canadian political landscape, rendering it fiercely partisan. This has manifested itself most clearly in how the Conservative prime minister has shaped Canada's relations with the United Nations.

Harper has done away with many of the givens that existed in Canadian foreign policy before he came to office: the classic liberal internationalist worldview, with its emphasis on multilateral cooperation with the $\mathrm{UN}$ and the other international organizations that took shape after the Second World War, is no longer an article of faith. He's replaced that with the mantra that Canada will "no longer just go along and get along with everyone else's agenda." (Harper 2011b)

The United Nations is now the political playing field for Canada's unabashed embrace of Israel, which has extended to an unprecedented opposition of various Palestinian statehood moves at the UN. Canada was pro-Israel before the Harper era began, but the country was never perceived as being anti-Palestinian, as it is now. While that likely wasn't the deciding factor in Canada's historic failure to win a seat at the UN Security Council in 2010, it certainly contributed to this landmark loss of face and influence.

Harper may now espouse — as the Conservatives have repeatedly claimed - a more robust principled foreign policy. But in a world seized with massive security threats from Russian encroachment into Ukraine, the war against Islamic State militants in Syria 
and Iraq, and a rise in homegrown terrorism in Europe and North America, Canada does not have — nor is it seeking — a seat at one of the world's most influential, albeit imperfect, tables of influence: the Security Council. The council has been plagued by gridlock almost since its founding, but holding a rotating seat on this body does give countries privileged backroom access to some of the most serious security discussions of our time.

The simple fact of the matter is this: countries such as Luxembourg, Rwanda, Angola, New Zealand, Lithuania, and yes, mighty Portugal, have been at that table for much of the post 9-11 era.

Canada has not, and most likely will not serve on it for the rest of this decade.

Under Harper's watch, Canada has shown indifference that borders on contempt for the UN's treaty process. Canada decided not to sign the Arms Trade Treaty because the government believes it will somehow constrain the rights of law-abiding, Canadian sports shooting enthusiasts, or that it might be a backdoor to reinstating the federal gun registry, a loathed piece of Liberal policy that the Conservatives dismantled once they had the majority of votes in the House of the Commons to do so. The United States, which has a ferocious gun lobby, has signed the treaty because that country doesn't see any threat to its citizens' protected constitutional right to bear arms. (Blanchfield "Firearms lobby") Canada pulled out of the Convention to Combat Desertification, a 20year-old treaty that looked at ways to deal with the loss of usable farmland to grow food in the face of encroaching deserts, especially in Africa, due to droughts. The government said it was too much talk and not enough action. Every other country in world — all 193 other members of the UN — disagreed, because they're still signatories. Canada signed 
the Convention on Cluster Munitions in 2008, but took six and a half years to ratify it in the face of intense international criticism of its ratification bill. The bill forbids Canadian military personnel from using the weapon, but would allow them to be indirectly involved in their use in joint missions with the United States, which — in its selfproclaimed role as the world's preserver of peace against tyranny — wants the right to continue to use them. The Americans join Russia, China, Israel, Pakistan as well as North and South Korea as non-signatories.

Harper has embraced the UN through his signature aid initiative to improve the health of mothers and babies in developing countries. But despite pledging billions to that worthy initiative, his government has slashed overall aid funding to lows not seen since the Liberal era of a decade and a half ago. Past Liberal and Progressive Conservative governments may have had periods where they were laggards on foreign aid spending. But the Trudeau and Mulroney governments did at least, for some of their respective eras in power, manage to maintain respectable levels of international assistance. The only aid increases that occurred on Harper's watch were in fulfillment of a previous Liberal promise. Meanwhile, Harper distinguished himself on another front — for the first time, Canada is lapsing hundreds of millions of aid dollars. It is simply not spending allocated funds, which means they get returned to the central treasury and can be used to help lower the broader federal deficit.

A combination of political ideology and domestic political necessity lies behind this new foreign policy direction. Harper's radical revamping of Canada's approach to international affairs has meant smashing the brand of past Liberal governments and 
crafting policies that can appeal to his base of core Conservative supporters, while attempting to attract other, more moderate mainstream support.

Despite what his critics may choose to believe, Harper may not have entirely lost faith in the ideals that brought the world together in San Francisco in 1945, at the end of a devastating global war, to create the United Nations. But Harper is clearly tired of the architecture of the post-war era, the institutions that Lester Pearson, General Andrew McNaughton and their contemporaries fought so hard to create and support, despite the internal flaws evident in those organizations - including the mother ship of multilateralism, the UN.

Black and Donaghy point to Harper's January 2010 speech at the World Economic Forum in Davos, Switzerland as one rare occasion during the current Conservative era when the country's traditional conceptualization of foreign policy was approvingly evoked, if only for a fleeting moment. The world was emerging from the 2008 recession, and Harper expressed hope in the long tradition of multilateralism because of how world leaders, particularly through the G20, first responded to the crisis at an emergency summit in Washington that year. "I saw world leadership at its best, a glimpse of a hopeful future - one where we act together for the good of all. The world we have been trying to build since 1945 . The world we want for our children and grandchildren," he said. (Harper 2010a) "It can be done if we act together. This is 'enlightened sovereignty'." (Ibid) Harper further defined this notion of enlightened sovereignty as "the natural extension of enlightened self-interest." (Ibid) This is perhaps the closest Harper has ever come to actually articulating how he sees the intersection of Canada's national interests with the broader, multilateral system. 
Despite that, Harper has a visceral and ideological aversion to subjecting his country to the rules of a broader international institution - in particular the UN. That was on full display during the March 2015 debate on extending the fight against ISIL into Syria.

Times are changing, and it is starting to seem that the rules of the traditional postwar institutions just don't apply the way they used to. In their book, Brave New Canada, authors Derek Burney and Fen Hampson argued that the "painful reality" is that the UN and the other international institutions that brought stability to the world at the end of the Second World War are becoming less effective and less relevant. (9) That also goes for the International Monetary Fund, World Bank, the World Trade Organization and NATO, they argue. "The declining effectiveness of these multilateral institutions has profound implications for middle powers like Canada as they search for traction in a rapidly changing world." (Ibid) This has led to an increasing need for "coalitions of the willing" to fill the void "only to prove that military muscle in itself is not an adequate response." (Ibid) But these coalitions have hardly produced positive results — witness the continuing instability in Iraq and Libya, and elsewhere. (10)

David Mulroney, Harper's first foreign policy adviser, has made a similar argument. Canada has been asleep at the switch in Asia, and it is now playing a desperate game of catch-up to break into new markets, especially in China. During his time as the ambassador there, from 2009 to 2012, Mulroney worked on making inroads for Canada with ASEAN, the 10-country Asian alliance that does not include China. But it has been an uphill struggle, because a lot of ground has been lost in the decades since the last right-of-centre government held power in Canada. "Everybody talks about Joe Clark," 
Mulroney told me, noting how the external affairs minister made numerous trips and scored many points by inviting his Asian counterparts to visit the scenic vistas of his home province of Alberta. “The point I make to ministers is: it isn't a huge investment, you've got to find the time, they like being invited, they like coming to Canada."

For the moment, there is little indication that Harper's political opponents would do things differently. Justin Trudeau, who seems to be Harper's only true challenger, is holding the Liberal party's foreign policy cards close to his chest in a calculated political strategy. But there are some signs of hope. Andrew Leslie, the former commander of the Canadian army during its bloodiest period in Afghanistan, argued, as have many others, that the imperfect UN is better than no UN, or the empty void of no international rules, or the law of the jungle that would fill that void. No soldier wants anarchy, and that includes Leslie.

"Is the United Nations perfect? Of course not," Leslie told me.

"But it's better than any alternative that I've seen, so you've got to work with the hand of cards you're dealt. We should be doing more with the UN."

Leslie said it is inevitable that Canada will one day return to the UN fold, but it will have to be after Harper has moved on. "People like Mr. Harper, who has his anti-UN bent, they come and they go," he said. "Being more inclusive and being more temperate doesn't mean you cave. You never want to abandon old friends, but there's lots of new friends we should be making out there."

David Mulroney agreed. He believes Canada is on a noticeable downward spiral internationally, something that did not exist under the governments of Brian Mulroney, 
Jean Chrétien or Paul Martin. Canada, he said, must find its way quickly, or there will be consequences.

"You can't reject the notion of getting along," he said.

"Be careful about the enemies you make in a globalized world. First of all, it's not a good idea to make enemies; you should find ways not to make enemies. Just in your self-interest, you often need other people and the way the world works, and the way life works is, the person you insult today, is the guy you're going to need tomorrow."

Stephen Lewis lamented the single-minded focus of the Harper government to use terrorism as a wedge issue to get reelected. He ignored, however, the fact that the NDP, a party he once headed in Ontario, and the Liberals are doing the same thing. That said, he agreed that the UN has serious problems. Lewis doesn't like the way it is being run by Secretary General Ban Ki-moon, and he's deeply concerned by the veto powers of the five permanent members of the Security Council. Lewis said it is time to consider serious reform of the UN system that would take the veto off the Security Council table when it is confronted by mass atrocities. Lewis lamented something else: the fact that Canada is nowhere to be heard in any serious discussion about how to fix an ailing institution it helped to build 70 year ago.

“Instead of Canada's voice being heard, instead of associating with new ideas and using the voice that we've had from Pearson right through to Paul Martin, we just don't say a Goddamned thing," Lewis said.

"If we say anything, it's usually truculent and unhelpful."

The writing of one of Canada's foremost post-war diplomats offers some timetested advice on moving forward. Some argue that the world is changing with 
unprecedented speed, and that this makes the reliance on old assumptions and truisms misguided and dangerous. But reading what renowned Canadian diplomat John Holmes wrote in 1970, as he reflected back on his foreign service career in the 1940s and 1950s, as Canada was emerging internationally, it is hard not find his words relevant — and instructive — in 2015. Holmes evoked Shakespeare's Falstaff who said, "The better part of valour is discretion." (Holmes vii) He was making an argument that subtlety and nuance — getting along with others and, perhaps, not engaging in self-interested grandstanding — was a more productive way to conduct international relations.

"Discretion in diplomacy is not incompatible with boldness of initiative in foreign policy or even with dramatic moves in international politics. The discretion is in the calculation of the issues at stake and the forces which can be mustered. Above all it lies in the recognition of contradiction and the acceptance of paradox," Holmes wrote. (Ibid) "This is a wisdom which Canadians might well ponder when they contemplate the foreign policies of their country. A sound foreign policy must be based on an acceptance of paradox. This is true for great powers, but it is especially true for a middle power whose reach ought not to exceed its grasp." (Ibid)

Tellingly, Holmes also added this: "There is an essential place in the making of foreign policy for loud advocacy, loud praise, or loud invective; and there is a place for quiet diplomacy." (Holmes viii)

All of the subtlety has been squeezed out of the Canadian foreign policy discussion by this country's increasingly polarized and partisan politicians. They shout at each other, and they shout at the world. The acceptance of paradox is probably the furthest notion from Stephen Harper's Manichean worldview. 
Where is the valour today in Stephen Harper continuing to pick a fight in Question Period long after the question has been asked, or in the deliberate strategic political posturing by the opposition parties?

Perhaps one day Canada will return to its past practice and try to get along in the world. But first, the people who represent all Canadians will have to learn to get along with each other. 


\section{Works Cited}

Axworthy, Lloyd. Navigating a New World: Canada's Global Future. Toronto: Vintage Canada. 2003. Print.

Bailey, Sue. "Canadian described bombing in the days before deadly strike." Whitehorse Star/The Canadian Press. 27 July 2006. Web. February 2015.

Baird, John. "Address by the Honourable John Baird, Minister of Foreign Affairs, to the United Nations General Assembly.” New York City. 26 September 2011. Speech.

---. "John Baird: Why Israel holds such a special place in my heart." National

Post. 20 November 2012. Web. January 2015.

---. "Minister Baird to the $68^{\text {th }}$ Session of the United Nations 'General Assembly.” New York City. 30 September 2013a. Speech.

---. "Standing Committee on Foreign Affairs and International Development."

19 November 2013b. Web. November 2013. Testimony.

"Baird maligns UN human rights council on Gaza resolution defends Israel." The

Canadian Press. 23 July 2014. Web. September 2014.

“Ban Ki-moon shares a story.” CTV News Channel. 30 May 2014. Web. 30 May 2014. Berthiaume, Lee. "Hundreds of millions in foreign aid go unspent, new figures show."

Ottawa Citizen. 12 July 2013. Web. January 2015.

Black, David and Donaghy, Greg. "Manifestations of Canadian Multilateralism."

Canadian Foreign Policy. Spring 2010. Web. January 2015.

Blanchfield, Mike. "Axworthy backs off criticism of UN: Security Council a 'powerful vehicle’ for security agenda." Ottawa Citizen. Web. 28 January 2000. December 2014. 
Blanchfield, Mike, Anne Dawson and Steven Edwards. "Liberals fight over Mideast policy: Rock speaks of pro-Israel shift.” National Post. 2 December 2004. Web. January 2015.

Blanchfield, Mike. "Canada in Afghanistan for long haul, Harper tells troops." Canwest News Service. 14 March 2006. Web. March 2006.

---. "Harper stands by his comment on Israel's 'measured' response." Montreal Gazette. July 2006. Web. July 2006.

---. 'UN observer's wife believes in miracles: Hope remains husband is alive in rubble.” 28 July 2006. Calgary Herald. Web. January 2015.

---. "Clinton pulls no punches at G8 summit; Meeting: U.S. Secretary of State surprises Tories on Arctic, Afghanistan, abortion.” Telegraph-Journal/ The Canadian Press. 31 March 2010. Web. March 2010.

---. "Canadian ex-arms negotiator breaks silence on cluster bombs." The Canadian Press. 1 April 2011. Web. October 2014.

---. "John Baird cut pro-Palestinian remarks from his UN address." The Canadian Press. 19 February 2012. Web. December 2015.

---. "Baird blasts UN rapporteur on Palestinian territories for bias against Israel.” The Canadian Press. 26 October 2012. Web. October 2012.

---. “Canada Opposes Palestine Bid." The Canadian Press. 29 November 2012. Web. November 2012.

---. “Canada recalls diplomats over vote.” Daily Gleaner. 1 December 2012. Web. February 2015. 
---. "Palestinians could face 'consequences' for pursuing Israel at the UN, says Baird." The Canadian Press. 5 March 2013. Web. March 2013.

---. "Canada quits UN drought convention." The Globe and Mail/The Canadian Press. 28 March 2013. Web. March 2013.

---. "Harper defends pulling out of UN desert convention, says it is too bureaucratic.” The Canadian Press. 28 March 2013. Web. March 2013.

---. "Canada's pullout from drought-fighting convention 'regrettable'." Telegraph-Journal/The Canadian Press. 30 March 2013. Web. March 2013.

---. "Red Cross, Norway raise questions about Canada bill banning cluster bombs." The Canadian Press. 17 June 2013. Web. The Canadian Press. October 2014.

---. The Canadian Press. "Cluster Bomb Victims Call For Action from Canada." Online video clip. Aol.com, 17 June 2013. Web. January 2015.

---. "Cluster bomb victims call on Canada to ratify convention to ban ‘dirty’ weapon. The Canadian Press. 18 June 2013. Web. October 2014.

---. "Laos asks Canada to restart funding to help clear deadly cluster bombs.” The Canadian Press. 24 June 2013. Web. October 2014.

---. "Young Laotians look ahead as they help clear deadly remains of Vietnam War." The Canadian Press. 26 June 2013. Web. October 2014.

---. "Canada rejects UN rights panel call for review of violence on aboriginal women." The Canadian Press. 19 September 2013. Web. August 2014. 
---. "Firearms lobby warns Ottawa against signing UN arms trade treaty." The Canadian Press. 2 October 2013. Web. October 2013.

---. "Baird to travel to Laos as Canada restarts funding to deal with cluster bombs.” The Canadian Press. 14 October 2013. Web. October 2014.

---. "Baird keeping open mind on cluster bomb bill but wants critics to hear him out." The Canadian Press. 25 October 2013. Web. October 2014.

---. “Former top soldier Natynczyk defends Canada's controversial cluster bomb bill. The Canadian Press. 21 November 2013. Web. October 2014.

---. 'World has lost 'one of its great moral leaders,' Harper says of Mandela." The Canadian Press. 5 December 2013. Web. December 2013.

---. "Tories change controversial cluster bomb bill by one word to assuage critics.” The Canadian Press. 10 December 2013. Web. October 2014.

---. "Canada praised for fighting forced marriages." Telegraph-Journal. 30 December 2013. Web. December 2013.

---. "Paradis says private sector a key partner in Harper maternal health initiative." Hamilton Spectator/The Canadian Press. 13 April 2014. Web. April 2014.

---. "Harper’s kids, moms aid plan for poor countries polarizes at home." The Canadian Press. 27 May 2014. Web. May 2014.

---. "Harper pledges \$3.5B to buttress maternal, child health initiative to 2020.” The Canadian Press. 29 May 2014. Web. May 2014.

---. "As summit wraps, Ban urges G7, including Canada, to boost foreign aid.” The Canadian Press. 30 May 2014. Web. May 2014. 
---. "Senate to hear more testimony on controversial cluster bomb legislation.” The Canadian Press. 22 October 2014. Web. December 2014.

---. "Tories urged to increase aid spending on youth reproductive health."

The Canadian Press. 18 November 2014. Web. November 2014.

---. "Ottawa lets $\$ 125 \mathrm{M}$ in aid to poor countries lapse amid new spending on kids." The Canadian Press. 20 November 2014. Web. November 2014.

---. “Axworthy welcomes Kerry musing on U.S. joining Ottawa landmines treaty.” The Canadian Press. 10 December 2014. Web. December 2014.

---. 'Baird meets Netanyahu, decries Palestinians' 'huge mistake' with ICC. The

Canadian Press. 19 January 2015. Web. January 2015.

---. "Foreign aid, poverty spending shrinking: PBO." The Canadian

Press. 23 January 2015. Web. January 2015.

---. "France's ambassador says Canada should take another run at UN

Security Council seat.” The Canadian Press. 28 January 2015. Web. January 2015.

--.. “Canada opposes 15 Palestinian attempts to join United Nations

treaties.” The Canadian Press. 6 February 2015. Web. February 2015.

---. "Baloney Meter: Is Canada's stature in the world growing, as John

Baird says?” The Canadian Press. 13 February 2015. Web. February 2015.

---. "Canada ratifies cluster bomb treaty after years of controversy." The Canadian Press.

17 March 2015. Web. March 2015.

---. "Israel thanks Canada for its help in gaining greater UN engagement." The Canadian Press. 17 March 2015. Web. March 2015.

---. "Canada Foreign Aid Spending Among Lowest of OECD Countries." The Canadian

Press. 8 April 2015. Web. April 2015. 
Bradach, Louise. Personal Interview. 21 October 2014.

Brewster, Murray. "John Baird unfazed by criticism after meeting with Israelis in East Jerusalem.” The Canadian Press. 11 April 2013. Web. December 2014.

Brynen, Rex. "Canada's Role in the Israeli-Palestine Peace Process." Canada and the Middle East In Theory and Practice. Eds. Paul Heinbecker and Bessma Momani. London: Wilfred Laurier University Press. 2007. Print.

Burney, Derek \& Fen Hampson. “No More Mr. Fixit at the UN.” iPolitics. 2012. Web. October 2012.

Burney, Derek \& Fen Hampson. "Stephen Harper is right to snub the UN." iPolitics. 2013. Web. September 2013.

Burney, Derek \& Fen Hampson. "Faster, fairer and more focused: How to fix the United Nations." iPolitics. 2014. Web. October 2014.

Burney, Derek H. and Fen Osler Hampson. Brave New Canada: Meeting the Challenge of a Changing World. Montreal \& Kingston: McGill-Queen's University Press. 2014. Print.

Canada. External Affairs (DEA). (1977) Message: Ministerial Level Security Council Meetings. (Orig. No.: UNO-1381). Ottawa, Ontario. Print.

“Canada, fire this diplomat.” Toronto Sun. 4 July 2011. Web. October 2014.

Canada. Foreign Affairs and International Trade Canada (DFAIT). (2012a). The Minister of Foreign Affairs Meeting with Sheldon Clare, President, Canada's National Firearms Association, May 9, 2012, 15:30 / Centre Block office. (BPTS: 00858-2012). Ottawa. Print. 
Canada. Foreign Affairs and International Trade Canada (DFAIT). (2012b).

Memorandum for Action. (BTPS: 02279-2012). Ottawa. Print.

Canada. Foreign Affairs and International Trade Canada (DFAIT). (2013). Memorandum for Action. (BTPS: 00993-2013). Ottawa. Print.

Canada. Foreign Affairs, Trade and Development Canada (DFATD). Canadian Policy on Key Issues in the Israeli-Palestinian Conflict. 13 January 2014. Web. February 2015. Canada. Foreign Affairs, Trade and Development Canada (DFATD). "Maternal, Newborn and Child Health.” 7 March 2014. Web. October 2014.

"Canada Gets Seat On Security Council: Given Votes To Spare on First Ballot." The Globe and Mail/The Canadian Press. 1 October 1947. Web. January 2015. Canada. Library of Parliament. (2012) Bill S-10: An Act to Implement the Convention on Cluster Munitions. (Publication No. 41-1-S10-E). 11 July 2012. Web. October 2014. Canada. National Defence (DND). (2006) Board of Inquiry: Death of Major P. Hess-Von Kruedener. (CF 285 (10-84)). 1 November 2006. Web. February 2015. Canada. Standing Senate Committee on Human Rights. (2008) Canada and the United Nations Human Rights Council: A Time for Serious Re-Evaluation. Web.

Canada. Standing Senate Committee on Human Rights. (2010) Canada and the United Nations Human Rights Council: Charting a new course. Web.

“Canada’s G8 Health Leadership.” The Lancet. 8 May 2010. Web. January 2015. Canada's International Policies: Agendas, Alternatives, and Politics. Eds.

Brian W. Tomlin, Norman Hillmer, Fen Osler Hampson. Toronto: Oxford University Press. 2008. Print.

CBC Newsmagazine. Guests: Howard Green, interviewed by Charles Lynch. 22 November 1959. CBC archives. Web. January 2015. 
Chapnick, Adam. "UN Security Council Reform and Canadian Foreign Policy: Then and Now.” Canadian Foreign Policy. 2006. Web. December 2014.

Chapnick, Adam. "The Gray Lecture In Canadian Citizenship and History." The American Review of Canadian Studies. Washington: Taylor and Francis.

Winter 2007. Web. December 2014.

Chase, Steven. "John Baird lands yet another job as adviser to Hong Kong billionaire. The Globe and Mail. 2 April 2015. Web. April 2015.

Clark, Joe. How We Lead: Canada In A Century of Change. Toronto: Random House. 2013. Print.

Cohen, Andrew. While Canada Slept: How We Lost Our Place In The World. Toronto: McClelland and Stewart. 2003. Print.

Cohen, Andrew. Lester B. Pearson. Toronto: Penguin Canada. 2008. Print.

"The Cowboy Way or Canadian Foreign Policy under a Majority

Conservative Government.” The McLeod Group. 2012. Web. May 2014.

Day, Adam. "One Martyr Down: The Untold Story of a Canadian Peacekeeper Killed at War.” Legion Magazine. 2 January 2013. Web. February 2015.

De Kerckhove, Ferry. Personal Interview. 6 February 2015.

Dewitt, David B. and John Kirton. Canada As A Principled Power: A Study in Foreign Policy and International Relations. Toronto: John Wiley \& Sons. 1983. Print.

Diefenbaker, John G. One Canada: Memories of the Right Honourable John G. Diefenbaker, The Crusading Years 1895-1956. Toronto: MacMillan and Canada. 1975.

Earnhardt, Roger. Personal Interview. 26 January 2015. 
Eayrs, James. The Art of the Possible: Government and Foreign Policy in Canada. Toronto: University of Toronto Press. 1961. Print.

Edwards, Steven. "Ottawa learns the real value of UN promises." National Post. 12 October 2010. Web. October 2010.

English, John. Just Watch Me: The Life of Pierre Elliott Trudeau 1968-2000. Toronto: Vintage Canada. 2009. Print.

Flanagan, Tom. Harper's Team. Behind The Scenes In The Conservative

Rise To Power. Montreal and Kingston: McGill-Queen's University Press. 2007.

Fogel, Shimon. Personal Interview. 22 February 2015.

Fortier, Yves. Personal Interview. 13 February 2015.

Fowler, Robert. "Why Canada was not elected to the Security Council ..." The United Nations and Canada: What Canada has done and should be doing at the United Nations. Ed. John E. Trent. Ottawa: World Federalist Movement. 2013. Print. Frechette, Louise. "Canada and the United Nations: A Shadow of Its Former Self." Canada Among Nations, 2009-2010: As Others See Us. Eds. Fen Osler Hampson and Paul Heinbecker. Montreal, Kingston: McGill-Queen's University Press. 2009. Galloway, Gloria. "Canada condemns UN 'hatefest.'” The Globe and Mail. 26 November 2010. Web. October 2014.

Goodman, Lee-Anne. "Harper, Netanyahu sign broad agreement at Jerusalem meeting." The Canadian Press. 21 January 2014. Web. January 2014.

Greenaway, Norma, Matthew Fisher and Aileen McCabe. “Terrible Tragedy.” Regina Leader Post. 27 July 2006. Web. February 2015.

Hampson, Fen Osler. “The Axworthy Years: An Assessment." Presentation prepared for National Press Club, Ottawa. 2000. Web. October 2014. 
“Harper announces $\$ 150 \mathrm{M}$ in aid for moms and kids during Senegal visit." The Canadian Press. 30 November 2014. Web. November 2014.

Harper, Stephen and Tom Flanagan. “Our Benign Dictatorship.” Next City Magazine 1996. Web. August 2014.

Harper, Stephen. "Rediscovering the right agenda: The alliance must commit to idea and ideas, not vague decision-making processes: The Canadian Alliance leader outlines how social and economic conservatism must unite." Citizens Centre Report. 2003a. Web. October 2014.

Harper, Stephen and Stockwell Day. "Canadians Stand With You.” Wall Street Journal. 28 March 2003b. Web. January 2015.

Harper, Stephen. “A departure from neutrality.” National Post. 23 May 2003c. Web. October 2014.

---. "Iraq.” Edited Hansard. Canada. Parliament House of Commons

HANSARD Iraq debates 2003. $37^{\text {th }}$ Parliament. $2^{\text {nd }}$ Sess. No. 048. 2003. Parliament of Canada. Web. October 2014.

---. "Address by the Prime Minister to the $61^{\text {st }}$ Opening Session of the United Nations General Assembly.” New York City. 21 September 2006b. Speech.

---. "Reviving Canadian Leadership in the World." Washington. 5 October 2006c. Speech.

---. "Statement by the Prime Minister of Canada at the World Economic Forum in Davos, Switzerland.” Davos, Switzerland. 28 January 2010a.

---. "Statement by The Right Honourable Stephen Harper Prime Minister of Canada to the General Debate of the 65 st Session of the United Nations General Assembly. New York City. 23 September 2010b. Speech. 
---. "Prime Minister Stephen Harper’s 2011 Convention Speech.” Ottawa. 16 June 2011 b.

---. "PM addresses the United Nations General Assembly in New York

City.” New York City. 25 September 2014. Speech.

Harris, Mike and Preston Manning. International Leadership by a Canada

Strong and Free. Montreal: Montreal Economic Institute. 2007. Print.

Heinbecker, Paul. Personal Interview. 11 February 2015.

“Here's Obama's legal case for bombing inside Syria.” Vox. 23 September 2014. Web. April 2015.

Hilliker, John and Barry, Donald. Canada's Department of External Affairs, Volume 2:

Coming of Age, 1946-68. Montreal and Kingston: McGill-Queen's University

Press. 1995.

Hillmer, Norman and J.L. Granatstein, Empire to Umpire. Toronto: Nelson, 2007.

Holmes, John. The Better Part of Valour. Toronto: McClelland and Stewart. 1970. Print.

Horton, Richard. “Offline: Canada’s Big Promise.” The Lancet. 7 June 2014. Web.

October 2014.

Huffington Post. "Mark Adler, Tory MP, Pleads To Get In 'Million Dollar Shot' Of

Harper At Holy Site.” 21 January 2014. Web. January 2014.

Huffington Post. "Stephen Harper Mocked Over Photos Of Empty Seats At UN

Address.” 26 September 2014. Web. September 2014.

Huffington Post. “Trudeau's 'Whip Out' Joke Criticized By Top Conservatives.” 2

October 2014. Web. October 2014.

Ibbitson, John. Stephen Harper. Toronto: McClelland and Stewart. Forthcoming.

“Israel invited to join UN's Western nations group in Geneva. Jerusalem Post.

2 December 2013. Web. February 2015. 
Johnson, William. Stephen Harper And the Future of Canada. Toronto: McClelland \& Stewart. 2005. Print.

Keating, Tom. Canada and World Order: the Multilateralist Tradition in Canadian Foreign Policy. Toronto: Oxford. 2002. Print.

“Killing of Major Paeta Hess-von-Kruedener.” Canada NewsWire. 28 July 2006. Web. February 2015.

Knowlton, Brian. “Allies at Summit Divided on Israeli Incursion.” New York Times. July 2006. Web. July 2006.

Lewis, Stephen. Personal Interview. 20 March 2015.

Lieber, Robert J. "Politics stops at the water's edge? Not recently." Washington Post. 10 February 2014. Web. February 2015.

Leslie, Andrew. Personal Interview. 5 February 2015.

Levitz, Stephanie. "Canada won't run for UN Security Council seat in 2014." The Globe and Mail. 1 May 2013. Web. December 2014.

Lloyd, Trevor. Canada in World Affairs: Volume X 1957-59. Toronto: Oxford. 1968.

MacCormac, Richard. Personal Interview. 20 October 2014.

Mackey, Lloyd. Stephen Harper: The Case For Collaborative Governance. Toronto: ECW Press. 2005. Print.

Malone, David. "Eyes on the prize: The quest for nonpermanent seats on the UN Security Council.” Global Governance. January-March 2000. Web. December 2014. Martin, Patrick. "Baird sticks to party line — Israel's Likud party.” The Globe and Mail. 3 February 2012. Web. January 2015. 
Massie, Justin and Stephane Roussel. "The Twilight of Internationalism?

Neocontinentalism as an Emerging Dominant Idea in Canadian Foreign Policy.” Eds.

Smith, Heather A. and Claire Turenne Sjolander. Canada in the World:

Internationalism in Canadian Foreign Policy. Oxford University Press. 2013.

Millennium Project. "The 0.7\% target: An in-depth look.” 2006. Web. October 2014.

Mulroney, Brian. Memoirs: 1939-1993. Toronto: McClelland \& Stewart. 2007.

Mulroney, David. Personal Interview. 9 March 2015.

“Mulroney On Harper's Supreme Court Spat: 'You Don't Do That'.” The Canadian

Press. 9 September 2014. Web. September 2014.

Natynczyk, Walter. "Proceedings of the Standing Senate Committee on Foreign Affairs and International Trade.” 21 November 2013. Web. December 2014. Testimony.

Nolan, Cathal J. "The Human Rights Committee." Human Rights in Canadian Foreign Policy. Eds. Robert O Matthews and Cranford Pratt. Kingston and Montreal: McGill-Queen’s University Press. 1988. Print.

Nossal, Kim Richard and Stephane Roussel, and Stephane Paquin. International Policy and Politics in Canada. Toronto: Pearson. 2011. Print.

Nossal, Kim Richard. "The Liberal Past in the Conservative Present: Internationalism in the Harper Era." Eds. Smith, Heather A. and Claire Turenne Sjolander. Canada in the World: Internationalism in Canadian Foreign Policy. Oxford: Oxford University Press. 2013. Print.

Nossal, Kim Richard. 'Primat der Wahlurne: Explaining Stephen Harper’s Foreign Policy.” International Studies Association. 2014. Web. July 2014. 
"Palestinians summon Canadian envoy over Baird's East Jerusalem meeting." The Canadian Press. 15 April 2013. Web. January 2015.

Panetta, Alexander. "Canada's big announcement at UN climate summit: Follow the U.S.” The Canadian Press. 23 September 2014. Web. September 2014.

Panetta, Alexander. "Days of easy 'middle path' for Canadian foreign policy are over."

The Canadian Press. 14 May 2014. Web. May 2014.

Payton, Laura. "UN official sparks debate over Canadian food security." CBC News. 16 May 2012. Web. February 2015.

Press Gallery. "Blues — Speeches on Government Motion/ Bleus — Discours sur la Motion du Government.” Message to the author. 24 March 2015. E-mail.

Press Gallery. "Blues.” Message to the author. 25 March 2015. E-mail.

Press Gallery. "Blues — from 10:14 - 13:59." Message to the author. 26 March 2015. E-mail.

Pugliese, David. "DND removes report on killing of Canadian soldier by Israeli forces." Ottawa Citizen. 25 December 2012. Web. January 2015.

"Questions Relating the Middle East, Chapter XI." The Yearbook of the United Nations. 1977. Web. February 2015.

Rasheed, Rashid and Daniel Estrin. "UN chief in Gaza voices shock at destruction from summer war as construction material arrives.” Associated Press. 14 October 2014.

Web. January 2015.

Rempel, Roy. Dreamland: How Canada's Pretend Foreign Policy Has

Undermined Sovereignty. Kingston: Breakout Educational Network. 2006. 
Riddell-Dixon, Elizabeth. "Canada at the United Nations 1945-1989.” International Journal. Vol. 62, No. 1. Winter 2006-07. Web. December 2014.

Rudd, Kevin. Personal Interview. 30 January 2015.

St. Laurent, Louis. "The Foundations of Canadian Policy in World Affairs.” Toronto. 13 January 1947. Web. January 2015. Speech.

Simpson, Jeffrey. "Harper's monumental determination. The Globe and Mail. 28 March 2015. Web. April 2015.

"The Situation in the Middle East, Chapter IX." The Yearbook of the United Nations. 1967. Web. February 2015.

Smith, Joanna. "Canada to double aid to Africa." Toronto Star. 23 March 2009. Web. January 2015.

Smith, Joanna. "Canadians don’t want foreign aid spend on abortions: Harper." Toronto Star. 27 April 2010. Web. December 2014.

Spencer, Robert A. Canada in World Affairs: From UN to NATO 1946-49. Toronto: Oxford University Press. 1959. Print.

Stacey, Kiran. "UK MPs back foreign aid target despite anger on right." Financial Times. 5 December 2014. Web. January 2015.

Stairs, Denis. "Being Rejected in the United Nations: The Causes and Implications of Canada's Failure to Win a Seat in the UN Security Council." Canadian Defence and Foreign Affairs Institute. 2011. n.pag. Web. July 2014.

“Stephen Harper's speech to the Israeli Knesset." CBC News. 20 January 2014. Web. January 2014. 
Tran, Mark. "US studies Israel's cluster bomb use in Lebanon.” The Guardian. 29 January 2007. Web. December 2014.

Turcotte, Earl. Personal Interview. 14 November 2014.

Turcotte, Earl. "Proceedings of the Standing Senate Committee on Foreign Affairs and International Trade.” 31 October 2012. Web. April 2013. Testimony.

United Nations Security Council. 7271st meeting. (S/PV.7271) 19 September 2014a. New York, NY.

United Nations Security Council. $7272^{\text {nd }}$ meeting. (S/PV.7272) 24 September 2014b. New York, NY.

United Nations Security Council. 4251st meeting. (S/PV.4251) 19 December 2000. New York, NY.

UN News Centre. “Israel's 'immoral' use of cluster bombs in Lebanon poses major threat — UN aid chief.” 30 August 2006. Web. April 2013.

“The UN's oil for food scandal: Rolling up the culprits.” The Economist. 15 March 2008. Web. April 2015.

"Use of Cluster Bombs." Cluster Munition Coalition (CMC). n.d. Web. 26 December 2014. February 2015.

Vastel, Marie and Olivier, Fannie. “Ottawa ignored its own advice on abortion, documents show.” The Canadian Press. 24 May 2010. Web. May 2010.

War Resisters Support Campaign — Canada. "Reason \#1 to Let War Resisters Stay — Stephen Harper admits the Iraq War was 'absolutely an error'.’ Online video clip. YouTube, 1 March 2009. Web. December 2014.

Wallin, Pamela. "Proceedings of the Standing Senate Committee on Foreign Affairs and International Trade.” 31 October 2012. Web. April 2013. Testimony. 
Wells, Paul. The Longer I'm Prime Minister: Stephen Harper and Canada, 2006 -.

Toronto: Random House. 2013.

Welsh, Jennifer. At Home in The World: Canada's Global Vision for the $21^{\text {st }}$ Century. Toronto: Harper Collins. 2004.

Wherry, Aaron. "Stephen Harper on the legality of bombing Syria: LOL." Maclean's. 26 March 2015. Web. March 2015. 